\title{
DIVERSIDADE MORFOLÓGICA, BIOQUIMICA E SEROLÓGICA DE DIAZOTRÓfICOS ASSOCIADOS A GRAMÍNEAS
}

\author{
IVANILDO EVÓDIO MARRIEL \\ Engenheiro Agrônomo \\ Orientador: Prof ${ }^{a} \operatorname{Dr}^{\text {a }}$ ELKE J.B.N. CARDOSO
}

Tese apresentada à Escola Superior de Agricultura "Luiz de Queiroz", da Universidade de São Paulo, para obtenção do título de Doutor em Agronomia, Área de Concentração: Solos e Nutrição de Plantas.

\author{
PIRACICABA \\ Estado de São Paulo - Brasil \\ Dezembro - 1996
}


Dados Internacionais de Catalogação na Publicação (CIP) DIVISÃO DE BIBLIOTECA E DOCUMENTAÇÃO - Campus "Luiz de Queiroz"/USP

Marriel, Ivanildo Evódio

Diversidade morfológica, bioquímica e serológica de diazotróficos associados a gramineas / Ivanildo Evódio Marriel. - - Piracicaba, 1996.

103 p. : il.

Tese (doutorado) -. Escola Superior de Agricultura Luiz de Queiroz, 1997.

Bibliografia.

1. Bactéria 2. Graminea 3. Fixação de nitrogênio 4. Inoculação 5 . Milho I. Titulo. 


\section{DIVERSIDADE MORFOLÓGICA, BIOQUÍMICA E SEROLÓGICA DE DIAZOTRÓFICOS ASSOCIADOS A GRAMÍNEAS}

IVANILDO EVÓDIO MARRIEL

Aprovada em 16.04.1997

Comissão julgadora:

Prof $^{\mathrm{a}} \mathrm{Dr}^{\mathrm{a}}$ Elke J.B.N. Cardoso

ESALQ/USP

Prof. Dr. Márcio Rodrigues Lambais

ESALQ/USP

Prof $^{\text {a }} \operatorname{Dr}^{\mathbf{a}}$ Siu Mui Tsai

CENA/USP

Dr. Helvécio De-Polli

CNPAB/EMBRAPA

Prof. Dr. Pedro Magalhães Lacava

IQ/UNESP

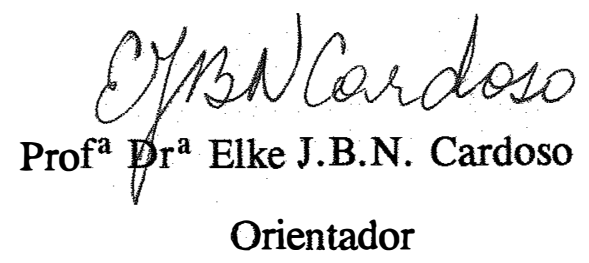


A DEUS

Pela luz

OFEREÇO 
À minha esposa Sara

Aos meus filhos, João Paulo

Mariana e Pedro Henrique

À minha mãe Estelina (in memoriam)

Ao meu pai Veredino

Aos meus irmãos, cunhados e sogros

DEDICO 


\section{AGRADECIMENTOS}

À Prof ${ }^{a} \operatorname{Dr}^{a}$. Elke J.B.N. Cardoso, pela orientação, amizade, incentivo e sobretudo pelo imensurável apoio e compreensão para a realização deste trabalho.

Aos Docentes da Escola Superior de Agricultura "Luiz de Queiroz" (ESALQ/USP), em geral, pelas valiosas informações e formação acadêmica. Em especial, aos Professores Geraldo Victorino de França e Márcio Lambais, pelo apoio e ajuda.

Aos Mestres, em geral, que, desde os primeiros passos contribuiram para a caminhada na trilha da informação científica.

Ao Departamento de Ciência do Solo da Escola Superior de Agricultura "Luiz de Queiroz"(ESALQ/USP), Empresa Brasileira de Pesquisa Agropecuária (Embrapa) e Embrapa Milho e Sorgo pela oportunidade oferecida para a realização do curso.

À Fundação de Amparo à Pesquisa do Estado de Minas Gerais (FAPEMIG), pelo auxílio fianceiro.

Aos amigos da Embrapa Milho e Sorgo pela solidaridade, em particular, ao Antônio Carlos de Oliveira e Fernando Tavares Fernandes, pela ajuda.

Aos Departamentos de Economia Rural, Área de Nutrição Humana e Alimentos e de Zootecnia Não Ruminantes da ESALQ/USP, pela manutenção das cobaias utilizadas no estudo. 
Aos colegas e amigos de curso Antônio Saraiva, Luiza Nakayama, Maria do Rosário, Rosana Vieira, Júlio Filho, Heron Costa, Willian Natale e Gaspar Gonsález, pela amizade e convívio.

Aos funcionários do Laboratório de Microbiologia do Solo (ESALQ/USP), Luis Fernando Baldessin e Denise L.C. Mescolotti, pela convivência amiga e pela colaboração.

As bolsistas Roberta, Elizabete, Conceição e Nádia, pela valiosa contribuição.

Aos Funcionários da Biblioteca Central da ESALQ/USP, em especial, a Kátia Maria de Andrade Ferraz, pela presteza e colaboração na correção das citações bibliográficas.

Aos Funcionários do Setor de Informação e Documentação da Embrapa Milho e Sorgo, pela obtenção das referências bibliográficas.

À amiga Clotilde Maria Batochio Cunha, pela datilografia e elaboração do texto.

À minha esposa, Sara, que, com amor e espírito de doação, permitiu superar os momentos difíceis e enriquecer as horas alegres.

A João Paulo, Mariana e Pedro Henrique, nossos filhos, razão de todo o esforço.

A todos que, direta ou indiretamente contribuiram para a realização deste trabalho. 


\section{SUMÁRIO}

LISTA DE TABELAS..................................................... ix

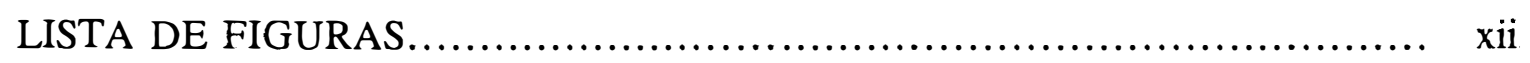

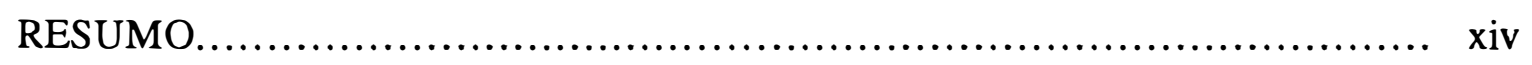

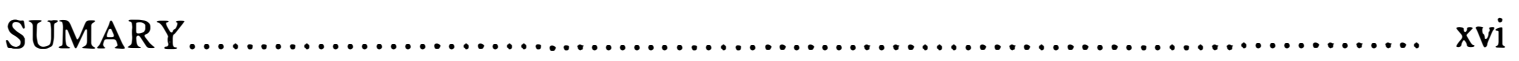

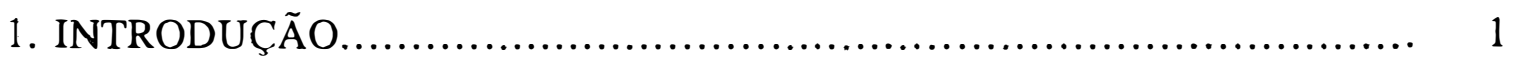

2. REVISÃO DE LITERATURA........................................... 5

2.1. Associação Azospirillum spp. - planta hospedeira.................... 8

2.2. Inoculação de cereais com Azospirillum spp....................... 13

2.3. Especificidade Azospirillum spp. - cereais........................ 16

2.4. Caracterização serológica de Azospirillum spp.................... 18

2.4.1. Enzyme-linked immunosorbent assay - ELISA............ 21

2.4.2. Dot-immunobinding assay - DIBA.................... 25

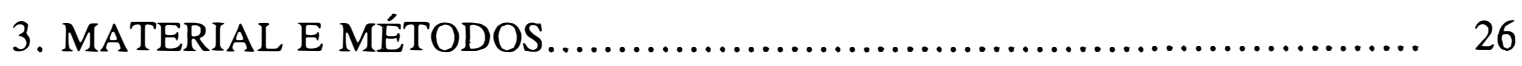

3.1. Isolamento e identificação de bactérias diazotróficas................ 26

3.2. Caracterização serológica de diazotróficos........................ 27

3.2.1. Preparação de imunógenos e imunização.................. 28

3.2.2. Determinação do título de anticorpos..................... 29

3.2.3. Enzyme-linked immunosorbent assay - ELISA............ 30

3.2.4. Dot immunobinding assay - DIBA.................... 31

3.3. Ocorrencia natural de endófitos diazotróficos de milho e sorgo ..... 32 
viii

3.4. Caracterização bioquímica de isolados de diazotróficos............. 32

3.5. Respostas de genótipos de milho à inoculação com Azospirillum ssp. 33

3.5.1. Efeito da inoculação com Azospirillum spp. sobre a morfologia do sistema radicular, crescimento e acúmulo de nutrientes em milho.

3.5.2. Efeito da inoculação com Azospirillum spp. sobre a atividade da redutase do nitrato

4. RESULTADOS E DISCUSSÃO

4.1. Isolamento e identificação de bacterias diazotroficas 37

4.2. Caracterização serológica de isolados de diazotróficos. 45

4.3. Ocorrência natural de endófitos em milho....................... 52

4.4. Caracterização bioquímica de isolados de diazotroficos ............ 55

4.5. Respostas de genótipos de milho à inoculação com Azospirillum spp. $\quad 58$

4.5.1. Efeitos da inoculação com Azospirillum ssp. sobre a morfologia do sistema radicular, crescimento e acréscimo de nutrientes em milho

4.5.2. Efeitos da inoculação com Azospirillum.ssp. sobre a atividade da redutase em milho. 


\section{LISTA DE TABELAS}

1 - Ocorrência de diferentes espécies de Azospirillum em algumas das amostras analisadas.

2 - Identificação numérica de bactérias diazotróficas, isoladas de origens diversas, agrupadas serologicamente através do teste ELISA.

3 - Limite de deteç̧ão de Azospirillum spp. em suspensão de células e especificidade dos antissoros, determinados em reações cruzadas entre os diferentes antígenos (Ag) e antissoros (As) através do teste ELISA.

4 - Valores de $\mathrm{pH}$ e teores de alguns macro e micronutrientes em seiva de 12 genótipos de milho, cultivados no campo sem inoculação artificial, no estádio de florescimento

5 - Diferenciação bioquímica de bactérias diazotróficas isoladas de gramíneas, através do kit API 20E.

6 - Acúmulo de matéria seca (g/planta ) na parte aérea e nas raízes de genótipos de milho cultivados em solução nutritiva, inoculados e não inoculados com uma mistura de estirpes homólogas de $A$. lipoferum e A.brasilense, 20 dias após a germinação. Médias de três repetições. 
7 - Teores médios de macronutrientes $\left(\mathrm{g} \mathrm{kg}^{-1}\right)$ na parte aérea de genótipos milho cultivados em solução nutritiva, inoculados e não inoculados com uma mistura de estirpes homólogas de $A$.lipoferum e $A$.brasilense, 20 dias após a germinação. Médias de três repetições.

8 - Conteúdos médios de macronutrientes ( $\mathrm{mg} /$ planta ) na parte aérea de genótipos de milho cultivados em solução nutritiva, inoculados e não inoculados com uma mistura de estirpes homólogas de A.lipoferum e A. brasilense, 20 dias após a germinação. Médias de três repetições.

9 - Teores médios de micronutrientes $\left(\mu \mathrm{g} \mathrm{g}^{-1}\right)$ na parte aérea de genótipos de milho cultivados em solução nutritiva, inoculados e não inoculados com uma mistura de estirpes homólogas de $A$.lipoferum e $A$.brasilense, 20 dias após a germinação. Médias de três repetições.

10 - Conteúdos médios de micronutrientes ( $\mu$ g/planta ) na parte aérea de genótipos de milho cultivados em solução nutritiva, inoculados e não inoculados com uma mistura de estirpes homólogas de A.lipoferum e A. brasilense, 20 dias após a germinação. Médias de três repetições.

11 - Teores médios de macronutrientes $\left(\mathrm{g} \mathrm{kg}^{-1}\right)$ em raízes de genótipos de milho cultivados em solução nutritiva, inoculados e não inoculados com uma mistura de estirpes homólogas de A.lipoferum e $A$.brasilense, 20 dias após a germinação. Médias de três repetições. 
12 - Conteúdos médios de macronutrientes (mg/planta ) em raízes de genótipos de milho cultivados em solução nutritiva, inoculados e não inoculados com uma mistura de estirpes homólogas de A.lipoferum e A.brasilense, 20 dias após a germinação. Médias de três repetições.

13 - Teores médios de macronutrientes $\left(\mathrm{g} \mathrm{kg}^{-1}\right)$ em raízes de genótipos de milho cultivados em solução nutritiva, inoculados e não inoculados com uma mistura de estirpes homólogas de A.lipoferum e A.brasilense, 20 dias após a germinação. Médias de três repetições.

14 - Conteúdos médios de micronutrientes ( $\mu \mathrm{g} /$ planta ) em raízes de genótipos de milho cultivados em solução nutritiva, inoculados e não inoculados com uma mistura de estirpes homólogas de A.lipoferum e A.brasilense, 20 dias após a germinação. Médias de três repetições.

15 - Somas parciais e total de intersecções de raizes de genótipos de milho cultivados em solução nutritiva, inoculados e não inoculados com uma mistura de estirpes homólogas de A.lipoferum e A.brasilense, 20 dias após a germinação. Média de três repetições.

16 - Atividade da redutase do nitrato em folhas e raízes de genótipos de milho cultivados em solução nutritiva, inoculadas ou não com uma mistura de estirpes homólogas de A.lipoferum e $A$.brasilense, 20 dias após a emergência. Médias de três repetições. 


\section{LISTA DE FIGURAS}

1 - Heterogeneidade morfológica de colônias de bactérias diazotróficas isoladas de gramíneas.

2 - Heterogeneidade morfológica de colônias de bactérias diazotróficas isoladas de gramíneas.

3 - Heterogeneidade morfológica de colônias de bactérias diazotróficas isoladas de gramíneas.

4 - Heterogeneidade morfológica de colônias de bactérias diazotróficas isoladas de gramíneas.

5 - Classificação serológica de 157 isolados de bactérias diazotróficas obtidos de origens diversas, através do teste ELISA.

6 - Limite de detecção de Azospirillum spp. em suspensão de células e especificidade dos antissoros, determinados em reações cruzadas entre os diferentes antígenos $(\mathrm{Ag})$ e antissoros (As), através do teste DIBA. 
7 - Ocorrência natural seletiva dos serogrupos A. lipoferum (59b) e A. brasilense (Sp7) em amostra de seiva de 28 genótipos de milho, cultivados no campo sem inoculação artificial, no estádio de florescimento, determinada através do teste DIBA.

8 - Ocorrência natural dos serogrupos A. lipoferum e $A$. brasilense em amostra de seiva de 63 genótipos de milho e 10 de sorgo, cultivados no campo sem inoculação artificial, no estádio de florescimento, determinada através do teste ELISA.

9 - Comparação do sistema radicular do genótipo de milho CMS 51 em solução nutritiva, inoculado e não inoculado com uma mistura de estirpes homólogas de A. lipoferum e $A$. brasilense, 20 dias após a germinação. 


\title{
DIVERSIDADE MORFOLÓGICA, BIOQUIMMICA E SEROLÓGICA DE DIAZOTRÓFICOS ASSOCIADOS A GRAMÍNEAS
}

\author{
Autor: IVANILDO EVÓDIO MARRIEL \\ Orientador: Prof ${ }^{\mathrm{a}} \mathrm{Dr}^{\mathrm{a}}$ ELKE J.B.N. CARDOSO
}

RESUMO

A fixação biológica de nitrogênio constitui uma tecnologia viável para o input de $\mathrm{N}$ na agricultura, visando sistemas agrícolas sustentáveis. Em gramíneas, a exploração do potencial das associações entre macro e microssimbionte depende, principalmente, na maioria dos casos, da identificação dos diazotróficos envolvidos. Neste trabalho, procurou-se: isolar, identificar e caracterizar serológica e bioquimicamente diazotróficos associados com estas culturas, com ênfase em milho e sorgo; avaliar as respostas de diferentes genótipos de milho cultivados em solução nutritiva à inoculação com Azospirillum spp. homólogos. A partir de amostras de solo, raízes de diferentes espécies de plantas, e seiva, estigma, grãos imaturos de milho foram obtidos e selecionados diferentes diazotróficos. Os resultados mostraram ampla distribuição das espécies A lipoferum e A. brasilense nas amostras analisadas dentre as bactérias identificadas, independentemente da planta hospedeira. Entretanto, encontrouse grande número de isolados que não se enquadrou nestas espécies de acordo com as 
características morfológicas, fisiológicas e bioquímicas utilizadas como parâmetros de identificação. A caracterização serológica efetuada com os soros policlonais específicos obtidos contra as espécies de $A$. lipoferum, $A$. brasilense $e$ A. amazonense, resultou em 6 serogrupos distintos entre os 157 isolados testados, utilizando-se das técnicas de ELISA. As técnicas ELISA e DIBA foram igualmente sensíveis para a diferenciação das espécies de Azospirillum em cultura pura. Mas, para a detecção de endofíticos em seiva de plantas, o teste DIBA mostrou-se aparentemente superior. Encontrou-se predominância quase absoluta de endófitos naturais antigenicamente próximos de $A$. lipoferum em seiva de milho e de sorgo, sugerindo ser esta espécie importante nestas plantas e indicando uma elevada especificidade nas interações bactéria-cereais. A caracterização bioquímica, através do kit API 20E confirmou a grande variabilidade entre os isolados. A inoculação com Azospirillum spp. homólogos estimulou a atividade da redutase do nitrato em folhas de milho, bem como, resultou em maior eficiência na absorção e acúmulo da mairia dos macro nutrientes, especialmente $\mathrm{N}$, e dos micronutrientes na parte aérea de milho, sendo esses efeitos dependentes do genótipo da planta. Os resultados mostram a possibilidade de se selecionar genótipos de milho superiores para fixação biológica de $\mathrm{N}_{2}$. 


\title{
MORPHOLOGICAL, BIOCHEMICAL AND SEROLOGICAL DIVERSITY OF DIAZOTROPHS ASSOCIATED TO GRAMINEAE
}

\author{
Author: IVANILDO EVÓDIO MARRIEL \\ Adviser: Prof ${ }^{3}$. Dr ${ }^{\mathrm{a}}$. ELKE J.B.N. CARDOSO
}

\section{SUMMARY}

Biological nitrogen fixation has become a viable technology for $\mathrm{N}$ input in sustainable agricultural systems. In grasses, among other factors, the optimization of these associations depend, mainly, on the identification of the main diazotroph involved in these interactions. The objective of this work was to isolate, identify and characterize, morphologically, serologically and biochemically, diazotrophs associated with these graminae crops, with emphasis on corn and sorghum. Also, to evaluate the responses to the inoculation with Azospirillum spp. of different corn genotypes cultivated in nutrient solution From soil samples, roots of different plant species, phloem sap, stigma, immature corn grains different diazotrophs were isolated. The results showed wide distribution of $A$. lipoferum and $A$. brasilense species among the identified bacteria, independent of the host plant. Notwithstanding, great number of isolates different from these species were found based on morphological, physiological and biochemical characteristics. The serological characterization by ELISA, with specific 
policlonal antibodies raised against $A$. lipoferum, $A$. brasilense and $A$. amazonense, resulted in 6 distinct serogroups among the 157 isolates tested. Both serological techniques were equally sensitive for the differentiation of Azospirillum species in pure culture. However, for the detection of endophytics in plant phlem sap, the DIBA test was more suitable. A nearly absolute dominance of natural endophytes antigenically related to $A$. lipoferum was observed in corn and sorghum phloem sap, suggesting that this is the main species established in these plants, and a high degree of specificity. The biochemical characterization, using the kit API 20E, confirmed a great variability between the isolates. The inoculation of corn with Azospirillum homologues stimulated the activity of the nitrate reductase in leaves, and resulted in a higher efficiency of absorption and accumulation of macro and micronutrients in shoots, except calcium and manganese. Nutritional effects were dependent of the plant's genotype. The results indicate the possibility for selection of maize genotypes more efficient in biological $\mathrm{N}_{2}$ fixation. 


\section{INTRODUÇÃO}

A população humana no globo tem apresentado uma taxa de crescimento anual em torno de $2 \%$ (FAO, 1992), o que implica necessariamente em um aumento na produção de alimentos. Uma maior disponibilidade de alimentos pode ser alcançada através do ganho nos índices de produtividade das culturas ou da expansão das fronteiras agrícolas, com a incorporação de novas áreas ao sistema produtivo. Entretanto, nos países com baixo índice de terras agricultáveis ociosas, o aumento de produção por unidade de área representa a única alternativa para o fornecimento adequado de alimentos.

Somente para ser mantida nos níveis atuais, a produtividade agrícola depende do reabastecimento das reservas de nutrientes que são removidos ou perdidos do sistema solo-planta. No caso do nitrogênio, o seu input nos sistemas agrícolas pode ser na forma de fertilizantes nitrogenados ou via fixação biológica de $\mathrm{N}_{2}$ atmosférico.

Na agricultura moderna, a adubação com nitrogênio mineral destaca-se entre as práticas utilizadas para o incremento de produtividade das culturas. $\mathrm{O}$ aumento de duas vezes da produção global de cereais ocorrido entre as décadas de 60 e 90 tem sido atribuido, em parte, ao aumento de 7 vezes no consumo de fertilizantes nitrogenados no mesmo periodo (Peoples et al., 1995). 
Entretanto, o uso de fertilizantes nitrogenados nos diferentes sistemas agrícolas depende, em última análise, de considerações econômicas e da presença efetiva de infraestrutura para produção e distribuição de fertilizantes. Esses fatos, conjugados com a baixa eficiência de utilização de $\mathrm{N}$ derivado de fertilizantes pelas plantas, raramente acima de 50\% (Oliveira et al., 1994), e a maior conscientização dos custos ambientais do $\mathrm{N}$ perdido de fertilizantes, têm sido considerados por alguns pesquisadores como fator inibidor no uso desses insumos em determinadas estruturas sócio-econômicas.

Embora altamente eficientes para a maximização de rendimentos físicos, os modelos agrícolas que apresentam elevada dependência de recursos externos à propriedade têm sido questionados quanto à sua sustentabilidade a longo prazo. Mesmo porque, os impactos negativos de tais sistemas sobre o ecossistema raramente têm sido debitados con os ganhos em produtividade (Tangley, 1986).

Nos dias atuais, a necessidade de se desenvolver sistemas agrícolas sustentáveis vem se transformando em foco de grande impacto para a agricultura mundial. Gradativamente aumenta a conscientização, não só da comunidade científica como, principalmente, da população em geral, preocupada com as conseqüências de uma agricultura intensiva que, invariavelmente, provoca degradação da qualidade do solo, do ar e da água. A amplitude dessa preocupação é sintetizada na frase atribuida a Suzuki (1990) "We no longer inherit the Earth from our parents, we borrow it from our children". Por outro lado, a fixação biológica de $\mathrm{N}_{2}$, utilizando fontes renováveis de energia, desempenha papel importante para a agricultura, reduzindo riscos do sistema 
produtivo e conservando a base de recursos agrícolas da propriedade. A contribuição deste processo para a ciclagem de nitrogênio pode prover a sustentabilidade em $\mathrm{N}$ para os mais variados ecossistemas do globo, sem os custos econômicos e ambientais da adubação química.

Entre os sistemas biológicos capazes de aproveitar o nitrogênio diretamente da atmosfera, a simbiose leguminosas-rizóbio é o mais especializado, respondendo por $22 \%$ de todo $\mathrm{N}$ incorporado ao ecossistema terrestre (Peoples et al., 1995).

O grande desafio da pesquisa no momento é a extensão destes processos biológicos para outras plantas, incluindo as gramíneas, especialmente, as de importância sócio-econômica. Em termos globais, os cereais constituem a base alimentar mais importante para a população humana e ocupam em torno de $50 \%$ das terras cultivadas. Somente as culturas de trigo, arroz e milho consumiram 53\% do total de fertilizantes utilizados no ano de 1991 (Peoples et. al., 1995). Esses dados justificam a grande euforia observada no meio científico com a descoberta, nos últimos anos, de que gramíneas também podem se beneficiar de quantidades economicamente significativas de $\mathrm{N}$ através da fixação biológica.

Esta nova área de pesquisa tem despertado particular interesse para países em desenvolvimento, cuja agricultura requer uma minimização de investimentos para permanecer como uma atividade sustentável e, especialmente, em regiōes tropicais, onde há melhores perspectivas de uma agricultura economicamente viável basear-se em nitrogênio fixado biologicamente. Dada a extensa área ocupada pelos cereais, 
aproximadamente 5 vezes maior que das leguminosas, a fixação biológica associada a estas culturas torna de extrema importância, mesmo que apenas parte de suas necessidades em $\mathrm{N}$ pudesse ser fornecida por este processo.

Para se desenvolver práticas agronomicamente viáveis ao aproveitamento desta fonte de $\mathrm{N}$, resta, ainda, conhecer e definir mais claramente fatores que intervém no processo, os mecanismos biológico e bioquímico da associação, bem como identificar o microrganismo principal responsável pelo sistema fixador efetivo nas interações com diferentes espécies de plantas. Pela sua extrema habilidade discriminatória, o uso de marcadores imunológicos pode contribuir para a determinação da importância de cada tipo de bactéria envolvida nestas interações e para a seleção de estirpes visando estudos de inoculação.

Os objetivos deste trabalho foram isolar, identificar e caracterizar morfológica, serológica e bioquimicamente isolados de diazotróficos associados a gramíneas e quantificar alterações morfológicas de raízes, crescimento e incorporação de nutrientes em plantas de milho que foram inoculadas com diazotróficos homólogos e cultivadas em solução nutritiva. 


\section{REVISĀO DE LITERATURA}

O desenvolvimento e a adoção de sistemas de manejo agrícolas sustentáveis têm recebido grande enfase internacional, nos dias atuais (Papendick \& Parr, 1992; Harwood, 1990).

Embora, com uma conceituação ainda complexa, uma agricultura sustentável envolve, como ponto básico, o manejo adequado dos recursos agrícolas de modo a satisfazer as necessidades humanas, enquanto mantém ou mesmo melhora a qualidade ambiental e conserva os recursos naturais (Harwood, 1990). Dentro deste ponto de vista, a sustentabilidade dos ecossistemas deve ser avaliada, levando-se em consideração também o relacionamento entre produtividade, diversidade biológica e qualidade do solo (Kennedy \& Smith, 1995). Esses autores comentam, ainda, que os programas de diversidade biológica tem negligenciado os microrganismos do solo, visto que, somente $13 \%$ dos microrganismos da Terra estão identificados e, consequentemente, uma vasta parcela da biota permanece desconhecida e não estudada.

Em geral, a capacidade de suprimento de $\mathrm{N}$ dos solos declina rapidamente com o incremento da atividade agrícola e o $\mathrm{N}$ derivado da mineralização da matéria orgânica tem de ser suplementado com outras fontes (Herridge et al., 1994). Com a ênfase internacional sobre o desenvolvimento sustentável ambientalmente, têm-se 
renovado as atenções sobre o potencial das diferentes associações biológicas como fonte de $\mathrm{N}$ para a agricultura

Após 100 anos da descoberta da existência do processo de fixação biológica de $\mathrm{N}_{2}$ (FBN) associado com leguminosas, observa-se grande progresso no entendimento da base molecular da interação entre macro e microssimbionte, além do observado no aspecto prático. Este processo, que utiliza fonte de energia renovável e conserva a base de recursos da propriedade, tornou-se uma tecnologia importante do ponto de vista sócio-econômico e ecológico. Estima-se que a contribuição da fixação biológica supera 170 milhões de toneladas de nitrogênio fixado para a biosfera (Earl \& Austubel, 1983), sendo que somente a simbiose rizóbio-leguminosas respondem por $22 \%$ deste total (Peoples et al., 1995).

Döbereiner \& Duque (1980) comentam que o grande desafio da pesquisa atual é a extensão deste fenômeno biológico para as plantas não leguminosas e que esforços de pesquisa consideráveis têm sido dedicado a esta área. Vários grupos de pesquisadores têm começado a explorar esta possibilidade através da indução de estruturas como nódulos, denominados de para-nódulos ou pseudo-nódulos, especialmente em cereais, embora os conhecimentos da base bioquímica e molecular destas interações planta-microrganismos, fisiologia da assimilação de nitrogênio e fixação de $\mathrm{N}_{2}$ sejam ainda incipientes.

Neste sentido, De Bruijn et al. (1995) apresentam uma revisão sobre o estado da arte no assunto e comentam os aspectos potenciais e limitações dessa nova 
associação entre bactérias fixadoras e gramíneas. Dentre as várias tentativas de se obter sistemas fixadores efetivos em cereais, têm-se utilizado tratamento químico (Tchan et al., 1991), tratamentos enzimáticos (Al-Mallah et al., 1989) microrganismos mutados ou transformados por engenharia genética (Rolf \& Bender, 1990) para a indução de pseudo-nódulos.

A infecção dessas estruturas por rizóbios ou diazotróficos de vida livre tem sido sugerido como veículo potencial pra que os cereais fixem seu próprio nitrogênio. Entretanto, até o momento, somente a inoculação de plantas de trigo com Azospirillum tratadas com 2-4D mostraram pseudo-nódulos com atividade da nitrogenase (Tchan et al. 1991).

Não obstante a existência de alguns resultados animadores nesta área, salienta-se que a concentração de esforços em sistemas naturais pode, a curto prazo, ser mais interessante, haja visto que nestes sistemas, diazotróficos endofíticos podem contribuir de modo significativo para o crescimento da planta hospedeira via fixação biológica, à semelhança do que tem sido descrito para a cana-de-açúcar e alguns cereais (Döbereiner et al., 1993; Boddey et al., 1995). Sugere-se, ainda, que parece suficiente identificar endofíticos estáveis na cultura de interesse e, se necessário, transformá- los geneticamente para fixar $\mathrm{N}_{2}$ eficientemente e excretá-lo para o uso da planta.

Do lado do hospedeiro, a maximização da eficiência da fixação associativa pode ser perseguida através do melhoramento da planta, visando maior eficiência na associação com a bactéria fixadora de $\mathrm{N}_{2}$. Neste caso, os trabalhos deveriam ser conduzidos sob condições de baixo $\mathrm{N}$ no solo para permitir a expressão 
do potencial de fixação e a discriminação de genótipos superiores e inferiores em relação a esta caraterística (Bliss, 1993)

\subsection{Associação Azospirillum spp. - planta hospedeira}

Os relatos iniciais e esporádicos sobre FBN associada com gramíneas tropicais só despertaram interesse, de fato, após a introdução do método de redução de acetileno, que permitiu estimativas mais precisas da atividade da nitrogenase "in situ" (Hardy et al., 1968). A medida da redução de acetileno surgiu a partir de observações de que a enzima fixadora de nitrogênio, a nitrogenase catalizava também a redução de acetileno $\left(\mathrm{C}_{2} \mathrm{H}_{2}\right)$ para etileno $\left(\mathrm{C}_{2} \mathrm{H}_{4}\right)$. Em razão da simplicidade, rapidez e sensibilidade na quantificação de etileno por cromatografia gasosa, este método desempenhou papel importante na pesquisa sobre FBN. Utilizando-se desta técnica, demonstrou-se fixação não-simbiótica em diferentes culturas como o arroz (Balandreau et al., 1976; Yoshida \& Ancajas, 1973), milho (Balandreau et al., 1974; Bülow \& Döbereiner, 1975; Dommergues et al., 1973) e algumas gramíneas forrageiras (Döbereiner et al., 1976). Esses resultados indicaram a importância da FBN em raízes de plantas não-leguminosas. Mas, somente mais tarde, através de outras metodologias, como balanço de $\mathrm{N}$, incorporação de ${ }^{15} \mathrm{~N}_{2}$ e diluição isotópica de ${ }^{15} \mathrm{~N}$, foi possível comprovar que, embora variáveis, quantidades economicamente importantes de $\mathbf{N}$ para a nutrição de arroz (Watanabe et al., 1987), sorgo (Giller et al., 1984), gramíneas forrageiras (De-Polli et 
al., 1977; Boddey \& Vitoria, 1986) e cana-de-açúcar (Lima et al., 1987), podiam ser derivadas do $\mathrm{N}_{2}$.

Entretanto, para se explorar estas associações naturais ou mesmo aumentá-las, os diazotróficos responsáveis tem de ser isolados e identificados e os mecanismos de suas interações com plantas melhor compreendidos (Döbereiner, 1989).

A partir das observações pioneiras de Döbereiner \& Day (1976) de que o uso de meios semi-sólidos era a condição ideal para o crescimento de diazotróficos dependentes de fixação biológica do nitrogênio da atmosfera, esta metodologia tem sido empregada extensivamente no isolamento e caracterização de microrganismos fixadores de diferentes plantas e de diferentes condições edafoclimáticas (Döbereiner et al., 1976), indicando que tais diazotróficos ocupam, preferencialmente, sítios onde a concentração de oxigênio seja limitada. Esta descoberta revolucionou e ampliou as pesquisas sobre todos os aspectos da fixação biológica nas associações entre diazotróficos e nãoleguminosas, denominadas mais comumente de interação associativa ou fixação de $\mathrm{N}_{2}$ associativa.

Döbereiner et al. (1993) e Döbereiner \& Pedrosa (1987) discutem detalhadamente os vários tipos destas interações, bem como, as diferentes bactérias fixadoras de $\mathrm{N}_{2}$ envolvidas já identificadas e classificadas nos diversos gêneros, incluindo Enterobacter, Klebsiella, Azotobacter, Azospirillum, Bacillus, Clostridium, Pseudomonas, Herbaspirillum, Acetobacter e outros. 
Entre os microrganismos diazotróficos encontrados em associaçöes com cereais e gramíneas, as espécies de Azospirillum constituem o grupo mais bem estudado, sendo numerosos os estudos sobre ecologia, fisiologia da associação com raízes, análise e manipulação genética (Bashan \& Levanony, 1990; Döbereiner \& Pedrosa, 1987; Döbereiner, et al., 1992 ). Assim, Azospirillum tornou-se um organismo modelo para estudos de interaçöes planta-diazotróficos (Michiels et al., 1989).

As bactérias do gênero Azospirillum foram isoladas a partir de raízes de Digitaria e classificadas inicialmente como Spirillum lipoferum (Döbereiner \& Day, 1974), Mais tarde, foi, então, proposto o gênero Azospirillum com duas espécies: $A$. lipoferum e $A$. brasilense (Tarrand et al., 1978), com base em diferenças morfológicas, fisiológicas e, em seguida, homologia de DNA. Atualmente, outras espécies já foram descritas: A. amazonense (Magalhães et al., 1983), isolada de gramíneas da Amazonia, A. halopraeferans (Reinhold et al., 1987), isolada de gramíneas do Paquistão e tolerantes a sais, e $A$. irakense (Khammas et al., 1989), isolada de plantas de arroz no Iraque.

A maioria das estirpes fixadoras de $\mathrm{N}_{2}$, isoladas de gramíneas tropicais, exceto de cana-de-açucar são referidas como $A$. lipoferum ou $A$. brasilense (Krieg \& Döbereiner, 1984). Essas espécies se diferenciam pela habilidade de crescer em glicose e pelo seu requerimento de biotina. Enquanto, $A$. lipoferum requer biotina e fixa $\mathrm{N}_{2}$ em meio com glicose como fonte de carbono, $A$. brasilense não metaboliza glicose e cresce na ausência de biotina (Döbereiner, 1993). 
Azospirillum spp. caracterizam-se como bactérias geralmente gramnegativas, tipo bastonetes, bastante móveis, com 0.8 a $01 \mu \mathrm{m}$ de diâmetro, 2 a $4 \mu \mathrm{m}$ de comprimento, com grânulos intracelulares de poli-hidroxibutirato. São aeróbios típicos, quando supridos com fonte de $\mathrm{N}$-combinado, e microaerofílicos quando dependem de FBN (Krieg \& Döbereiner, 1986). Em meio semi-sólido formam uma película delgada ou balão abaixo da superfície do meio, onde a concentração de oxigênio permite a fixação de nitrogênio para iniciar o seu crescimento (Okon, 1985). Com a continuação do crescimento e maior exigência de oxigênio, há o movimento da película em direção à superfície, onde se torna densa.

A associação entre as bactérias deste gênero e raízes das plantas depende de uma interação mútua e íntima entre o macro e o microssimbionte. Embora sem uma demonstração inequívoca da sua contribuição no processo de fixação biológica, o estabelecimento de Azospirillum, inoculado ou não, em cereais, está bem documentado (Baldani et al., 1987; Döbereiner \& Pedrosa, 1987; Boddey et al., 1995).

Considera-se que este processo se inicia com a colonização do sistema radicular do hospedeiro, onde provavelmente as bactérias alcançam os sítios de infecção através de quimiotaxia e/ou aerotaxia (Barak et al., 1983; Okon, 1984). Estudos estruturais em raízes de milheto e de microscopia ótica em milho, trigo e sorgo (Magalhães et al., 1979 ; Patriquin \& Döbereiner, 1978; Patriquin et al., 1983) sugerem que a invasão das raízes deve ocorrer longitudinalmente, a partir da infecção pelos pontos de emergência das raízes laterais até atingir as raízes principais. A colonização 
ocorre nos espaços inter e intracelulares dos tecidos cortical, parenquimatoso e xilema.

O estabelecimento de Azospirillum nos espaços intracelulares do xilema tem sido atribuido à presença de ácido málico, importante constituinte da seiva de milho (Butz \& Long, 1979), e à marcante preferência destas bactérias por ácidos orgânicos (Tarrand et al., 1978). O ácido málico é a fonte de carbono para crescimento ótimo de Azospirillum em meio de cultura (Döbereiner, 1980). Deste modo, o xilema tem sido considerado por Döbereiner (1983) como principal sítio de fixação biológica na associação milho-Azospirillum em razão não só da disponibilidade de ácidos orgânicos, como também da existência de baixa pressão parcial de oxigênio nesse local, condição essencial para a atividade da nitrogenase.

Magalhães et al. (1979) estimaram a população de Azospirillum durante o ciclo vegetativo do milho cultivado no campo. Nas avaliações, encontraram maior número de bactérias, $10^{7}$ a $10^{8}$ células por grama de raízes esterilizadas, no período reprodutivo, coincidindo com a época de atividade da nitrogenase mais elevada. Esses dados indicam que a fixação de nitrogênio ocorre principalmente no interior das raízes.

Michiels et al. (1989) enumeram algumas propriedades para a capacidade competitiva destas bactérias na rizosfera: a) Azospirillum são atraídas quimiostaticamente para a rizosfera pelos exsudatos das raízes e apresentam metabolismo altamente versátil, o que lhes permite sobreviver sob condições adversas no solo; b) podem aderir à superfície das células radiculares com rapidez; c) alguns isolados podem penetrar nas 
raízes e colonizar espaços inter e intra-celulares; d) várias estirpes de Azospirillum produzem substâncias bactericidas, inibidores de outros microrganismos na rizosfera, e sideróforos, que possibilitam uma aquisição eficiente de ferro; e) podem diferenciar-se em cistos e sobreviver melhor sob condições de estresses ambientais.

\subsection{Inoculação de cereais e gramíneas com Azospirillum}

Em sequência à identificação dos primeiros isolados de Azospirillum, houve grande interesse em testar o efeitos de tais bactérias em plantas cultivadas no campo e em condições controladas. Boddey \& Döbereiner (1988) citam que nos anos seguintes a redescoberta de Azospirillum foram conduzidos em torno de 100 ensaios sobre inoculação em gramíneas, incluindo cereais. A inoculação com esta bactéria tem se mostrado efetiva em aumentar a atividade da nitrogenase e proporcionar ganhos, principamente, no acúmulo de matéria seca, produção de grãos e concentração de nitrogênio e outras características agronômicas na maioria dos estudos.

Okon (1985) apresentou resultados de um levantamento sobre sucesso de inoculação com Azospirillum e concluiu que em $65 \%$ dos casos houve respostas significativas sobre produção de matéria seca e/ou produção de gramíneas. Em geral, o efeito da inoculação com Azospirillum sobre produção situa-se em torno de 10 a $30 \%$, e em alguns casos, valores mais elevados de 50 a $250 \%$, em relação ao controle nãoinoculado, têm sido mencionados (Bashan \& Levanony, 1990). 
Em relação à cutura de milho, após o trabalho de Bülow \& Döbereiner (1975) mostrando significativa fixação de $\mathrm{N}_{2}$, com base na atividade da nitrogenase, em plantas cultivadas no campo sem inoculação, vários estudos têm sido conduzidos com esta cultura visando avaliar o efeito da inoculação, sendo encontrados alguns com efeitos positivos (Magalhães et al., 1979; Cohen et al., 1980; Freitas et al., 1982, Hegazi et al., 1983; Kapulnik et al., 1982) e outros sem efeito (Albrecht et al., 1977). Em Israel, onde os solos possuem baixa ou nenhuma população nativa de Azospirillum, as respostas à inoculação são mais consistentes, e a recomendação desta prática já apresenta aspectos comerciais (Okon, 1985).

De acordo com Bashan \& Levanony (1990) aumentos moderados, em torno $20 \%$, atribuidos à inoculação com diazotróficos seriam considerados comercialmente significativos na agricultura moderna. Os autores consideram ainda que uma das variáveis básicas que contribuem para a complexidade das respostas à inoculação é a interação dos genótipos da planta e da bactéria. O efeito do genótipo da planta sobre a fixação associativa tem sido amplamente demonstrado em cereais, incluindo o milho e sorgo (Bülow \& Döbereiner, 1975; Bülow, 1978; Holl, 1983).

Em muitos casos, a ausência de resposta à inoculação tem sido atribuida ao uso de estirpes inadequadas (Döbereiner \& Duque, 1980), pois foi desconsiderada certa compatibilidade que pode existir entre a bactéria e a planta hospedeira. Baldani \& Döbereiner (1980) testaram diferentes estirpes inoculadas em trigo de origens diversas e concluiram que estirpes homólogas tendem a ser mais eficientes do que as 
isoladas de plantas de outras espécies. O trabalho de Baldani et al. (1983) também apresenta respostas positivas com plantas de trigo inoculadas com bactérias isoladas da própria cultura e ausência de respostas quando se utilizaram estirpes isoladas de milho.

Como bactérias diazotóficas, acreditava-se que a fixação de $\mathrm{N}_{2}$ na rizosfera ou dentro da raiz, e liberação de parte do nitrogênio fixado para a planta constituisse o principal modo de ação de Aospirillum no hospedeiro. Entretanto, ntre os efeitos estimuladores de crescimento de plantas, este processo paree não ocorrer em vários estudos, onde se observaram respostas positivas à inoculação com tais bactérias ( Boddey \& Döbereiner, 1988).

Algumas estirpes de Azospirillum produzem hormônios de crescimento em cultura pura (Bottini et al., 1989; Tien et al., 1979) e sabe-se que essas substâncias alteram a morfologia do sistema radicular, aumentam a densidade de raízes e interferindo no crescimento das plantas inoculadas. Boddey et al. (1986) utilizaram o método de diluição isotópica de ${ }^{15} \mathrm{~N}$ para estimar a contribuição da fixação em plantas de trigo cultivadas em vasos. $\mathrm{O}$ aumento de $\mathrm{N}$ nos grãos foi atribuida ao maior aproveitamento do $\mathrm{N}$ do solo e do fertilizante.

Diferentes mecanismos alternativos para os efeitos da inoculação têm sido propostos: a) efeitos hormonais que alteram o metabolismo e o crescimento da planta, visto que Azospirillum ssp. produzem diferentes hormônios de crescimento em cultura pura (Bottini et al., 1989; Crossier et al., 1988; Fallik et al., 1989; Horemans et al., 
1986; Tien et al., 1979); b) aumento do sistema radicular, possivelmente relacionado à alteração no balanço hormonal da planta, resultando em maior absorção de nutrientes e água e, em conseqüência, maior acúmulo de matéria seca (Okon, 1985; Okon \& Kapulnik, 1986; Sarig et al., 1988; Lin et al., 1983); c) atividade de redutase do nitrato da bactéria na raíz, aumentando o acúmulo de nitrato em plantas inoculadas (Boddey et al., 1986; Ferreira et al., 1987); d) redução da taxa de respiração e aumento da atividade de enzimas relacionadas ao ciclo de Krebs (Hadas \& Okon, 1987).

Não existem dados quantitativos de cada um destes mecanismos, entretanto, a hipótese mais provável é a participação simultânea ou sucessão de diferentes mecanismos na interação planta-bactéria. De acordo com esta hipótese,talvez, Azospirillum seja melhor definido como rizobactéria promotora de crescimento de plantas (RPCP) (Bashan \& Levanony, 1990).

\subsection{Especificidade Azospirillum spp. - planta hospedeira}

Nas associações simbióticas entre rizóbio e leguminosas há uma extensa lista de publicações demonstrando os mecanismos que governam a especificidade entre os macro e microssimbiontes. Em geral, estão envolvidos metabólitos produzidos pelas plantas que agem como sinais para o início do processo da nodulação e fixxação de $\mathrm{N}_{2}$.

No processo de fixação biológica associativa com Azospirillum, por outro lado, a ocorrência de tais mecanismos ainda é uma questão controvertida. Mas, uma 
série de resultados disponíveis na literatura indica a existência de certo grau de especificidade entre Azospirillum e seus hospedeiros.

A primeira evidência experimental sobre especificidade hospedeira na associação com gramíneas foi descrita por Baldani \& Döbereiner (1980). Quando as bactérias foram isoladas de raízes lavadas de milho, trigo ou arroz, cultivados em vasos ou no campo, não houve predominância consistente de nenhuma das espécies de Azospirillum testadas. Por outro lado, quando as raízes foram desinfestadas superficialmente com cloramina T, encontrou-se predominância de $A$. lipoferum entre os isolados obtidos de milho e de A.brasilense entre os de arroz e de trigo. Em ensaios posteriores, sob condições de campo, utilizando-se esta técnica de desinfestação, os trabalhos mostraram que, em geral, em plantas $\mathrm{C}_{4}$ predominavam isolados de $A$. lipoferum e nas gramíneas $C_{3}$ predominavam $A$. brasilense (Baldani et al., 1987); Döbereiner \& De-Polli, 1980). Resultados similares foram obtidos em zonas temperadas (Haahtela et al., 1981; Lamm \& Neyra, 1981). Em contraste, essa especificidade não foi observada em outros estudos (Bashan \& Levanony, 1990; Okon \& Kapulnik, 1986), onde a inoculação com uma única estirpe afetou positivamente diferentes espécies de plantas.

Barak et al. (1983) e Reinhold et al. (1985) demonstraram que células de Azospirillum respodem positivamente a quimiotrativos como aminoácidos, aúcares e ácidos orgânicos e, portanto,esses compostos desempenam papel importante na colonização do sistema radicular das plantas. Como a composição dos exsudatos varia com o 
genótipo da planta, pode-se especular o envolvimento de algum composto no estabelecimento preferencial de determinada espécie de bactéria em uma planta hospedeira.

Por outro lado, em alguns casos, a falta de especificidade pode ser explicada pela baixa densidade de Azospirillum nativo nos solos utilizados para competir com as estirpes inoculadas (Boddey \& Döbereiner, 1988). Bashan \& Levanony (1990) enfatizam a importância da seleção de estirpes como ponto crucial na determinação da especificidade e consideram que grande número de estirpes tem de ser isoladas a partir de diferentes origens, caracterizadas e testadas sob diferentes condições ambientais para cada espécie de planta.

\subsection{Caracterização serológica de Azospirillum spp.}

Considera-se como pré-requisito importante para se obter uma resposta eficiente da inoculação com estirpes de bactérias diazotróficas, selecionadas ou manipuladas geneticamente, a sua multiplicação na rizosfera e estabelecimento no interior da planta no campo, onde ocorre a competição com estirpes nativas e outros microrganismos. En retanto, faltam técnicas metodológicas que possam ser usadas rotineiramente, permitindo uma diagnose segura do sucesso do estabelecimento de determinada estirpe na planta, principalmente no estádio inicial de crescimento. Estes fatores constituem a principal barreira para a indicação de estirpes adequadas para a inoculação de cereais. 
Diferentes métodos, incluindo teses bioquímicos, imunológicos, fisiológicos, mutação de estirpes para resistência a antibióticos e técnicas moleculares foram desenvolvidos e propostos para superar essas dificuldades.

Por sua alta aplicabilidade acadêmica e prática, os testes imunológicos têm recebido atenção crescente nas pesquisa sobre associações biológicas. Esses métodos baseiam-se na extraordinária capacidade discriminatória dos anticorpos, em razão da habilidade do sistema imune dos vertebrados em produzir uma variedade virtualmente ilimitada dessas imunoglobulinas, sendo cada uma dotada de afinidade singular para compostos específicos.

As técnicas serológicas foram inicialmente usadas na microbiologia clínica ou médica (Brock \& Madigan, 1988), cujo princípio básico é a interação antígeno-anticorpo. De acordo com esses autores, antígenos são substâncias que podem ser capturadas especificamente pelos anticorpos do sistema imune dos vertebrados. Quando injetados de maneira apropriada em animais, os antígenos elicitam uma resposta imune, iniciando a síntese de anticorpos específicos, sendo referidos como imunógenos. Os anticorpos são direcionados para partes restritas de uma macromolécula, chamadas de determinantes antigênicos. Cada componente induzindo um anticorpo específico é um determinante antigênico, mais frequentemente denominado de epítopo (Boonekamp, 1988).

A parede celular e a membrana plasmática de bactérias gram-negativas são constituidas de uma mistura de lipídios, proteínas e carboidratos complexos que 
respondem por $80 \%$ da matéria seca da parede celular (Phaff, 1981). A maioria destes constituintes celulares é composa de antígenos com propriedades imunogênicas e, portanto, possibilitam diferenciar serologicamente microrganismos com base em variações na composição destes polímeros.

O uso de anticorpos tem desempenhado papel essencial no desenvolvimento da biotecnologia. Anticorpos são amplamente utilizados em pesquisas básicas e diagnose de doenças humanas e vegetais.

Dois tipos de anticorpos podem ser distinguidos: anticorpos policlonais e monoclonais. Os anticorpos policlonais são purificados a partir de uma fração de soro de sangue de um animal imunizado. Representam uma mistura complexa de anticorpos direcionados contra diferentes determinantes antigênicos e com afinidades diversas (Neumeier, 1984). Estes tipos de soro contém anticorpos produzidos a partir de diferentes clones de célula $\mathrm{B}$ ( = policlonal) contra vários epítopos do antígeno,além dos muitos anticorpos presentes no sangue do animal antes da imunização.

Em contraste, os anticorpos monoclonais são produzidos por células oriundas de um único clone e, portanto, constituidos de uma única imunoglobulina. O princípio básico é isolar células de linfócitos B produtoras de anticorpos de um animal adequadamente sensibilizado e multiplicar esses clones. Como células de linfócitos B não sobrevivem em cultura de células, elas são fusionadas com células de mielomas, para formar linhagens de células B híbridas (hibridomas), que crescem em cultura, sintetizando exatamente o mesmo anticorpo (Kohler \& Milstein, 1975). 
Existem vários métodos serológicos usados para detectar e monitorar microrganismos em associações simbióticas, especialmente entre leguminosas e rizóbio, dentre eles, os baseados em imunorreagentes marcados com enzimas como as técnicas ELISA e DIBA.

\subsubsection{Enzyme-Linked Immunosorbent Assay (ELISA)}

As determinações imunoenzimáticas, baseadas em imunorreagentes marcados com enzimas, especialmente anticorpos, têm ocorrido em escala crescente nos laboratórios de diagnose.

Ao contrário do uso de testes com radioimunoensaios que apresentam limitações impostas por legislação de vários países, em razão dos riscos que apresentam à saude e à curta meia vida de seus reagentes, a técnica "enzyme-linked immunosorbent assy" (ELISA), introduzida por (Engvall \& Perlmann, 1971), utiliza reagentes estáveis, livres de limitação de uso e, mais importante, é adaptável tanto aos testes simples como aos automatizados Outra característica marcante deste método é que antígenos morfologicamente diversos como proteinas, ácidos nucleicos, bactérias, vírus, fungos, dentre outros, têm sido diagnosticados com alta sensibilidade e especificidade. Esses fatos contribuiram para a rápida expansão e aplicação destes procedimentos (Voller \& Bidwell, 1986).

ELISA baseia-se na premissa que um imunorreagente pode ser imobilizado na superfície de um suporte sólido, mantendo sua atividade inalterada, enquanto o 
imunorreagente recíproco pode ser ligado a uma enzima, de tal modo que a reatividade enzimática e a imunoreatividade deste conjugado também são mantidos (Voller \& Bidwell, 1986).

Através desta técnica, a serologia tornou-se uma ferramenta, também importante, para classificação, identificação e detecção de microrganismos em plantas (Clark, 1981; Figueiredo et al., 1977), etapas estas, indispensáveis nos estudos de FBN.

Para os processos simbióticos com rizóbio, os métodos serológicos são amplamente utilizados para identificação de estirpes e incluem também aglutinação, imunodifusão, imunofluorescência.

Kishinevsky \& Bar-Joseph (1978) e Kishinevsky et al. (1982), utilizando testes serológicos para identificação de rizóbio, mostraram que ELISA apresenta sensibilidade de 4 a 6 vezes maior que o teste de aglutinação ou de imunodifusão. A maioria dos procedimentos descritos para identificação de rizóbio (Kishinevsky et al., 1982; Olsen et al., 1983; Martenson et al., 1984), têm empregado anticorpos policlonais no sistema de detecção. Como as diferentes espécies de bactérias possuem antígenos comuns, os anticorpos policlonais apresentam alta freqüência de reações cruzadas, principalmente entre estirpes de uma mesma espécie, tanto de rizóbio (Wright et al., 1986), como de Azospirillum (Dazzo \& Milan, 1976; De-Polli et al., 1980; Klossak \& Bohlool, 1983), não permitindo a diferenciação entre elas. 
Uma maior especificidade das técnicas serológicas tornou-se possível com a introdução da tecnologia de hibridoma (Kohler \& Milstein, 1975). Com esta tecnologia, a produção de anticorpos monoclonais tem fornecido reagentes imunológicos homogêneos e bioquímicamente definidos com especificidade única e extrema habilidade discriminatória. Anticorpos monoclonais apresentam vantagens em relação ao antissoro policlonal em testes serológicos pois reagem com um único determinante antigênico (epítopo) em maior proporção do que com epítopos e/ou antígenos diferentes; estes anticorpos específicos para epítopo único podem ser produzidos mesmo quando imunógenos mistos são usados para imunização (Jordan \& Hammond, 1988; Jordan et al., 1989) e também apresentam disponibilidade imediata por um período indefinido, sem perda de qualidade.

Segundo Halk \& DeBoer (1985) e Jordan et al., (1989), anticorpos monoclonais específicos para vários patógenos de plantas, incluindo virus, bactérias, micoplasmas, têm sido produzidos e usados em estudos diagnósticos e taxonômicos.

Wright et al. (1986) produziram anticorpos monoclonais para uma estirpe de rizóbio e mostraram que estes anticorpos podem ser utilizados para detectar a mesma estirpe em cultura e em nódulos de planta. Velez et al. (1988) selecionaram 13 hibridomas capazes de produzir anticorpos para antígenos somáticos de Bradyrhizobium japonicum e utilizaram o teste ELISA para avaliar a reatividade destes anticorpos contra 20 estirpes de B. japonicum. Estes autores afirmam que embora os antissoros 
monoclonais tenham sido mais específicos, os policlonais também identificaram todas as estirpes testadas.

Estudos imunológicos constituem uma das áreas mais negligenciadas nas pesquisas sobre fixação de $\mathrm{N}_{2}$ associativa envolvendo Azospirillum. Em consequência, conhece-se muito pouco a respeito dos antígenos desta bactéria. Os trabalhos disponíveis revelam que anticorpos policlonais podem ser usados com sucesso nos estudos da rizosfera para detectar e enumerar Azospirillum. Num dos primeiros relatos sobre o assunto (Schank et al., 1979), células de Azospirillum foram identificadas qualitativamente, utilizando anticorpos fluorescentes. Dados similares foram obtidos com outras técnicas imunológicas (Ladha et al., 1982; Matthews et al., 1983; Levanony et al., 1987). Antígenos específicos para Azospirillum brasilense foram detectados em exopolissacarídeos e flagelos (Levanony \& Bashan, 1989).

O desenvovimento de marcadores imunológicos utilizando anticorpos monoclonais apresentam prespectivas promissoras também para o entendimento dos mecanismos envolvidos nas interações entre diazotróficos e gramíneas. Entretanto, as informações pioneiras nesta área são recentes (Scholter et al., 1992) e apresentam expansão limitada até o momento (Scholter et al., 1993). E sua produção exige infraestrutura ainda de custo elevado. 


\subsubsection{Dot Immunobinding Assay (DIBA)}

Os procedimentos serológicos para detecção de bactérias imobilizadas sobre membranas têm sido utilizados há muitos anos. A técnica possui o mesmo princípio do teste ELISA, mas difere no suporte sólido para adsorver o material a ser testado, que é membrana e não microplaca. Mais comumente, a técnica de DIBA envolve aplicação da amostra à membrana e sua incubação em uma solução contendo anticorpo específico. Em seguida é tratada com um conjugado enzimático enzimaanticorpo anti-imunoglobulina que reage com imunoglobulina ligada à membrana. A atividade da enzima é revelada pela adição de um substrato apropriado, que após conversão, precipita para formar um "spot" colorido.

Estudos de caracterização imunológica de microrganismos, especialmente de vírus, utilizando-se DIBA têm sido mais comumente usados por causa de sua simplicidade e aplicabilidade para um grande número de amostras (Lazarovits, 1990). 


\section{MATERIAL E MÉTODOS}

\subsection{Isolamento e identificação de bactérias diazotróficas}

O isolamento de estirpes de Azospirillum spp e outros diazotróficos foi efetuado utilizando-se meio semi-sólido, de acordo com a metodologia preconizada por Döbereiner (1980).

Foram coletadas amostras de plantas de milho (raízes, seiva, estigma e grãos em início de formação) e de sorgo (raízes e seiva), além de solo e de outras gramíneas cultivadas em diferentes regiões de Piracicaba (SP), São Carlos (SP), Sete Lagoas (MG) e Alegre (ES). No laboratório, as suspensões, de cada material, foram preparadas em solução salina $(\mathrm{NaCl}, 0,85 \%)$ e transferidas para quatro meios diferentes, $\mathrm{NFb}$, JNFb, LGI e LGI (Döbereiner et al., 1995) contidos em frascos tipo penicilina com $5 \mathrm{ml}$ de cada meio. Após o aparecimento de uma película típica de Azospirillum spp., foi efetuada a transferência de parte dela para novo meio de cultura NFb semisólido e incubado a $33^{\circ} \mathrm{C}$. No início da formação de nova película, as culturas foram riscadas em placas com meio $\mathrm{NFb}$ sólido (15g/1 de ágar) acrescido de $20 \mathrm{mg} / 1 \mathrm{de}$ extrato de levedura e incubadas durante $4-5$ dias a $33^{\circ} \mathrm{C}$. Em seguida, as colônias típicas de Azospirillum foram testadas em relação à atividade da nitrogenase e 
transferidas para placas contendo meio ágar-batata para a purificação final. Os isolados obtidos foram caracterizados e identificados através de aspectos morfológicos das colônias, exames microscópicos e caracterização fisiológica, exigência de biotina e fixação de $\mathrm{N}_{2}$ na presença de glicose como fonte de carbono (Döbereiner, et al., 1995). Os isolados de diazotróficos selecionados foram armazenados em frascos com meio sólido de cultura ágar-batata, cobertos com óleo mineral esterilizado, para posterior caracterização serológica e bioquímica.

\subsection{Caracterização serológica de isolados de diazotróficos}

Para a caracterização serológica dos isolados, utilizaram-se antissoros específicos obtidos para as estirpes A.lipoferum (sp 7), A.brasilense (59b) $e$ A.amazonense (A14) consideradas como padrões, através dos métodos ELISA e DIBA. As culturas padrões foram cedidas pelo Centro Nacional de Pesquisa de AgrobiologiaEmbrapa, Km 47, Seropédica, Rio de Janeiro.

Cada isolado purificado foi plaqueado em meio de cultura ágar-batata sólido (Döbereiner, 1980). Após 5 dias de crescimento a $32^{\circ} \mathrm{C}$, uma colônia isolada foi retirada e inoculada em 50ml de meio líquido NFb ou LGI (Döbereiner et al., 1995), sem corante, contendo $1 \mathrm{~g} / 1$ de $\mathrm{NH}_{4}{ }^{+}$. Após incubação, sob agitação,durante 48 horas, as culturas de células foram centrifugadas a a $4500 \mathrm{xg}$, durante 8 minutos, e ressuspensas em solução tampão PBS, pH 7,2. A suspensão final foi ajustada a uma 
densidade ótica de 0,800 com filtro de $520 \mathrm{~nm}$, o que equivaleu a uma concentração aproximada de $5 \times 10^{9}$ células viáveis por $\mathrm{ml}$, determinada através da técnica de microgotas (Hoben \& Somasegaran, 1982).

\subsubsection{Preparação do imunógeno e imunização}

Para obtenção dos imunógenos, as células de cada uma das estirpes padrões liofilzadas foram rehidratadas com uma solução contendo $10 \%$ de sacarose e $5 \%$ de peptona esterilizada. Uma alíquota da suspensão de células, através de uma alça de platina, foi transferida e riscada em placa contendo meio ágar-batata sólido. Após 5 dias de crescimento a $32^{\circ} \mathrm{C}$, uma colônia isolada foi retirada e transferida para $2 \mathrm{ml}$ de meio $\mathrm{NFb}$ líquido, ascrescido de $1 \mathrm{~g} / 1$ de $\mathrm{NH}_{4} \mathrm{Cl}$. Após 24 horas de crescimento a $32^{\circ} \mathrm{C}$, transferiu-se $1 \mathrm{ml}$ para erlenmeyer de $250 \mathrm{ml}$ contendo $100 \mathrm{ml}$ do mesmo meio. A cultura foi incubada a $32^{\circ} \mathrm{C}$ durante 72 horas. Em seguida, as células foram centrifugadas a $4500 \mathrm{xg}$ durante 10 minutos, ressuspensas em solução tampão PBS, pH 7,2, $\left(8,0 \mathrm{~g} / 1 \mathrm{NaCl} ; 0,2 \mathrm{~g} / 1 \mathrm{KCl} ; 1,44 \mathrm{~g} / 1 \mathrm{Na}_{2} \mathrm{HPO}_{4} ; 0,24 \mathrm{~g} / 1 \mathrm{KH}_{2} \mathrm{PO}_{4}\right)$. Esta operação foi repetida 3 vezes. Após dois períodos de aquecimento de 1 hora a $56^{\circ} \mathrm{C}$ com intervalo de 20 minutos, cada cultura de células foi centrifugada, ressuspensa em PBS e ajustada a uma densidade ótica de 0,800 à $520 \mathrm{~nm}$. Essa densidade equivale a aproximadamente $10^{9}$ células viáveis por $\mathrm{ml}$, contadas pelo método de microgotas (Hoben \& Somasegaran, 1982). 
Uma alíquota de $1 \mathrm{ml}$ da suspensão de células, misturadas com adjuvante completo de Freund comercial na proporção de 1:1, foi injetada, por via intramuscular, em um coelho raça Nova Zelândia, com aproximadamente $2,6 \mathrm{~kg}$ de peso. Foram efetuados 5 reforços com a suspensão de células misturada com adjuvante incompleto de Freund, proporção 1:1, sendo o primeiro 15 dias após a imunização inicial 1 e os demais com intervalo entre 25-30 dias, até aos 90 dias.

\subsubsection{Determinação do título de anticorpos}

Para a detecção de anticorpos, o sangue de cada animal imunizado foi coletado, efetuando-se um corte longitudinal na veia marginal da orelha Depois da coleta, o sangue foi mantido em temperatura ambiente por 2 horas, em seguida deixado em geladeira durante à noite. O soro foi centrifugado a aproximadamente $8000 \mathrm{~g}$, durante 4 minutos, fracionado em alíquotas de $0,5 \mathrm{ml}$ e congelado. $\mathrm{O}$ soro normal negativo foi obtido um dia antes da inoculação do imunógeno.

Os anticorpos específicos foram detectados através de reações recíprocas entre os antígenos e antissoros de cada espécie bacteriana, utilizando-se diluições seriadas $1 / 2$ dos antissoros, através dos testes ELISA e DIBA, descritos a seguir. Testes preliminares indicaram a concentração adequada de antígeno a ser utilizada para cada estirpe. 


\subsection{Enzyme-linked immunosorbent assay - ELISA}

Neste teste, avaliou-se o relacionamento serológico de 173 isolados de origens diversas, através de reações recíprocas contra as espécies $A$. lipoferum, $A$. brasilense e A. amazonense. Uma colônia de cada estirpe, isolada em meio de batata sólido, foi transferida para meio NFb líquido e incubada por 72 horas a $32-34^{\circ} \mathrm{C}$, sob agitação leve. Após este período, as células foram centrifugadas, lavadas, ressuspensas em PBS e ajustadas a uma densidade ótica de 0,800 D.O. a $520 \mathrm{~nm}$.

Utilizou-se a técnica ELISA indireto como descrito por Ahmad et al., (1981) com modificações. Alíquotas de $100 \mu \mathrm{L}$ foram adicionadas em cada cavidade da placa Elisa e incubadas durante a noite, a $37^{\circ} \mathrm{C}$. No dia seguinte, o antígeno foi

descartado e a placa lavada 3 vezes com PBS, pH 7,2, contendo 0,05\% de Tween 20 (PBS-T) e seca. Após a adição de $250 \mu \mathrm{L}$ de uma solução de saturação (PBS com 0,5 \% de caseina, PBS-C) e incubação por 1 hora à temperatura ambiente, a placa foi lavada novamente 4 vezes. Em seguida, adicionou-se o primeiro anticorpo, (antissoro contra $A$. lipoferum, A. brasilense ou A. amazonense) e deixou-se à temperatura ambiente por 2 horas. Após 5 lavagens e secagens, foram aplicados $100 \mu \mathrm{L}$ de uma solução de anti-imunoglobulina de coelho, conjugada com fosfatase alcalina, diluida 1:3000 em PBS-T, e incubou-se novamente durante 2 horas à temperatura ambiente. Após a lavagem final, foram adicionados $100 \mu \mathrm{L}$ da solução do substrato, p-nitrofenol (PNP) na concentração de $1 \mathrm{mg} / \mathrm{ml}$ e a absorbância resultante foi medida a $405 \mathrm{~nm}$, com um espectrofotômetro Mutiskan. 


\subsubsection{Dot-immunobinding assay - DIBA}

No teste DIBA, utilizou-se a metodologia preconizada por Lazarovits, (1990), com modificações. Utilizou-se um aparelho para microfiltração dot-blot (BioRad) constituído basicamente de uma placa superior com 96 cavidades, similar à placa para ELISA, uma lâmina de plástico seladora; uma placa suporte da lâmina seladora e uma base com saída para conexão a fonte de vácuo.

A membrana de nitrocelulose, previamente umedecida em TBS (20 mM Tris- $\mathrm{HCl} \mathrm{pH} \mathrm{7,5;500mM} \mathrm{NaCl),} \mathrm{foi} \mathrm{fixada} \mathrm{adequadamente} \mathrm{entre} \mathrm{a} \mathrm{placa} \mathrm{de} 96$ cavidades e a lâmina seladora. Uma alíquota de $100 \mu \mathrm{L}$ do antígeno em consideração foi depositada em cada cavidade da placa superior e deixada filtrar pela força da gravidade. Após a drenagem completa da amostra, adicionaram-se $200 \mu \mathrm{L}$ de TTBS-caseina (TBS; Tween 20, 0,05\%; caseina, 0,5\%) em cada cavidade e deixou-se drenar novamente sem vácuo. Em seguida, efetuaram-se 3 lavagens consecutivas da membrana, adicionando-se $300 \mu \mathrm{L}$ de TTBS por cavidade e drenando a vácuo. Então, aplicaram-se $100 \mu \mathrm{L}$ do primeiro anticorpo específico e após drenagem completa por gravidade, o excesso foi removido a vácuo. Lavou-se novamente por 3 vezes consecutivas com $300 \mu \mathrm{L}$ de TTBS e adicionou-se o segundo anticorpo, anti-imunoglobulina de coelho conjugada com fosfatase alcalina. Após filtragem completa por gravidade, efetuou-se nova lavagem por

2 vêzes. A deteç̧ão foi feita com a solução de substrato com 5-bromo-cloro-2indolfosfato (BCIP) e o corante cloreto de 4-nitro azul de tetrazólio (NBT), $300 \mu \mathrm{L}$ por cavidade. Depois da drenagem por gravidade, aplicaram-se $200 \mu \mathrm{L}$ de água destilada, 
incubando no escuro por 30 minutos. A membrana foi removida do aparelho, lavada em água destilada e seca ao ar. As reações positivas aparecem como "spot" coloridos e as negativas sem cor.

\subsection{Ocorrência natural de endofíticos diazotróficos em milho e sorgo}

Os antissoros específicos para A.lipoferum, A.brasilense e A.amazonense foram utilizados para determinar a presença destes serogrupos de bactérias em seiva de 63 genótipos de milho e 10 genótipos de sorgo, cultivados no campo, sem inoculação artificial.

Para a obtenção de seiva, coletaram-se 3 plantas de cada um dos genótipos testados. As plantas foram transportadas para o laboratório, onde os colmos foram limpos e desinfetados com álcool. Em seguida, os colmos foram cortados, e os entrenós submetidos a pressão positiva de ar para coleta de aproximadamente $2 \mathrm{ml}$ de seiva, em tubos de ensaio esterilizados. Antes de ser testada, a seiva foi foi filtrada, usando um pré-filtro (Millipore AP25 025 00), para eliminação de partículas em suspensão. As amostras de cada material foram avaliadas utilizando-se os testes ELISA e DIBA, como desritos no itens 3.2.3 e 3.2.4, respectivamente.

\subsection{Caracterização bioquímica de isolados de diazotróficos}

Com o objetivo de confirmar a variabilidades encontrada entre os isolados em termos serológicos e morfológicos, avaliou-se o padrão bioquímico de 25 isolados, 
selecionados com base no relacionamento antigênico entre eles, incluindo representantes dos serogrupos previamente determinados. As estirpes foram testadas usando o kit API 20E (Appareils et Procédes d'Identification- API System S.A., A., France), fornecido pela BIO-LAB, composto de diferentes carboidratos e enzimas importantes no metabolismo microbiano.

Inicialmente, cada isolado foi reavaliado quanto à sua pureza, através da riscagem em placa com meio ágar-batata sólido. As galerias do kit API foram preparadas de acordo com as recomendações do fornecedor. Uma colônia isolada de cada estirpe foi diluida em $5 \mathrm{ml}$ de água destilada esterilizada e inoculada nas galerias. Após 18 e 24 horas a $33^{\circ} \mathrm{C}$, efetuou-se a leitura das reações positivas e negativas, com base nas alterações de cor, em função dos indicadores.

\subsection{Resposta de genótipos de milho à inoculação com Azospirillum spp.}

\subsubsection{Efeito da inoculação com Azospirillum sobre a morfologia do sistema radicular, crescimento e acúmulo de nutrientes em milho}

Para avaliar o impacto da inoculação com estirpes homólogas de Azospirillum, isto é, isoladas de milho, sobre a morfologia do sistema radicular e no crescimento de milho conduziu-se um experimento em casa-de-vegetação, em solução nutritiva, de acordo com método preconizado por Schwarz \& Geisler (1991). 
Utilizaram-se 5 cultivares de milho: CMS 13, CMS 36, BR 451, Sintético Elite e CMS 51, do Banco de Germoplasma da Embrapa/Milho e Sorgo, Sete Lagoas, MG. Essas cultivares foram selecionadas no campo, sob estresse de $\mathrm{N}$, e consideradas contrastantes para eficiência no uso de $\mathrm{N}$ e/ou para FBN (Marriel et al., 1991).

As sementes foram desinfetadas superficialmente com uma soluçâo de hipoclorito de sódio (5\%), durante 1 hora, e lavadas com água destilada esterilizada por 5 vezes. Quinze sementes de cada genótipo foram colocadas, de modo equidistante, sobre uma placa de acrílico medindo 50 x $40 \mathrm{~cm}$, coberta com uma folha de papel de filtro e fixadas com tiras do mesmo papel medindo $50 \times 10 \mathrm{~cm}$. Estas placas foram colocadas inclinadas, aproximadamente 15 graus, e distanciadas $1,5 \mathrm{~cm}$ uma da outra, em um recipiente plástico, com capacidade para 140 L (Apêndice 1). As raízes foram banhadas até a altura das sementes com uma solução nutritiva com a seguinte composição (mg/L): $\mathrm{NH}_{4} \mathrm{NO} 3,10 ; \mathrm{KH}_{2} \mathrm{PO}_{4}, 136 ; \mathrm{K}_{2} \mathrm{SO} 4,89 ; \mathrm{MgSO}_{4} \cdot 7 \mathrm{H}_{2} \mathrm{O}, 429$; $\mathrm{CaCl}_{2} \cdot 2 \cdot \mathrm{H}_{2} \mathrm{O}, \quad 442 ; \quad \mathrm{MnSO}_{4} \cdot 1 \mathrm{H}_{2} \mathrm{O}, \quad 1,52 ; \quad \mathrm{ZnSO}_{4} \cdot 7 \mathrm{H}_{2} \mathrm{O}, \quad 0,22 ; \mathrm{CuSO}_{4}, \quad 0,07 ;$ (NH4) $\mathrm{MO}_{7} \mathrm{O}_{24} \cdot 4 \mathrm{H}_{2} \mathrm{O}, 0,37 ; \mathrm{H}_{3} \mathrm{BO}_{3}, 0,74$ e Fe-Chelat (“Sequestren”), 25.

Esta solução, contida em tanque separado, era bombeada para o recipiente em intervalos de 2 horas durante o dia $\mathrm{e} 4$ horas durante à noite. A solução foi trocada a cada período de 7 dias.

Para a inoculação, utilizou-se uma mistura de 4 estirpes homólogas de Azospirillum, sendo 2 obtidas a partir de raizes e 2 de seiva. As células de cada estirpe foram multiplicadas em meio $\mathrm{Nfb}$ líquido com $1 \mathrm{~g} / 1$ de $\mathrm{NH}_{4}{ }^{+}$até a fase logarítmica, 
lavadas e ressuspensas em solução salina $(0,85 \%$ de $\mathrm{NaCl})$. A concentração de células foi ajustada para $5 \times 10^{9}$ células viáveis por $\mathrm{ml}$ de suspensão, na contagem em placa pelo método da microgota.

As características morfológicas das raizes foram avaliadas aos 18 dias após a germinação através da contagem das intersecções entre as raízes e as linhas horizontais de um grid constituido de uma folha de plástico riscada com espaços de $2 \mathrm{~cm}$. As características resultantes foram assumidas como soma de intersecções. Este parâmetro combina número e comprimento de raízes seminais e laterais.

As somas de intersecções foram analisadas para o perfil do sistema radicular inteiro e para 3 zonas diferentes de profundidades de raízes $(\mathrm{A}=0-12 \mathrm{~cm}$; $\mathrm{B}=12-24 \mathrm{~cm} \mathrm{e} \mathrm{C}=24-36 \mathrm{~cm})$.

Dois dias após, as plantas foram removidas dos vasos, separando-se o sistema radicular da parte aérea. Os materiais, após secagem a $65^{\circ} \mathrm{C}$ em estufa com circulação forçada de ar, foram pesados e triturados em moinho tipo Wiley, equipado com peneira 60 mesh, para determinação dos teores de macro e micronutrientes por espectrofometria de plasma induzido.

\subsubsection{Efeito da inoculação com Azospirillum spp. sobre a atividade da redutase do nitrato}

A atividade de redutase do nitrato in vivo foi determinada de acordo com o método proposto por Hageman \& Reed (1980), com modificações. 
A amostragem de folhas e de raízes para a determinação da enzima foi efetuada entre 9 e 10 horas da manhã. A parte mediana das folhas mais novas totalmente expandida, sem nervuras, de 5 plantas, constituiram cada amostra dos tratamentos analisados. As amostras coletadas foram colocadas imediatamente em um isopor contendo gêlo. No laboratório, os materiais foram cortadas em pedaços de aproximadamente $1 \mathrm{~cm}$ e pesadas. Incubou-se $0,250 \mathrm{~g}$ de folha ou $500 \mathrm{mg}$ de raízes de cada amostra em um meio de incubação constituido de $0,1 \mathrm{M}$ de $\mathrm{K}_{2} \mathrm{HPO}_{2,} \mathrm{pH} 7,5 ; 0,1 \mathrm{M}$ $\mathrm{KNO}_{3} ; 1 \%$ de n-propanol e $0,05 \%$ de Neutronix a $0,05 \%$ ) em banho maria a $30^{\circ} \mathrm{C}$, no escuro. Após incubação de 10 e 40 minutos, uma aliquota de $0,5 \mathrm{ml}$ do meio de incubação de cada amostra foi retirada e adicionada a 2,5 $\mathrm{ml}$ de água destilada e 3,0 ml da solução contendo $1 \%$ de sulfanilamida dissolvida em $\mathrm{HCl} 1,5 \mathrm{~N}$. O nitrato produzido foi quantificado pela adição de N (1-naftil) etilenodiaminodihicloreto a $0,02 \%$, após 20 minutos do início do desenvolvimento de cor e a absorbância lida em espectrofotômetro, a $540 \mathrm{~nm}$. Com base em uma curva padrão, obteve-se a concentração em micromoles de $\mathrm{NO}_{2} \cdot \mathrm{h}^{-1} \cdot \mathrm{g}^{-1}$ de matéria fresca de folha e de raizes. 


\section{RESULTADOS E DISCUSSÃO}

\subsection{Isolamento e identificação de bactérias diazotróficos}

De uma maneira geral, comparados com outros grupos de microrganismos, as bactérias apresentam elevada diversidade na rizosfera e endorrizosfera das plantas e somente pequena parcela desses organismos é conhecido (Hawksworth, 1991).

O aproveitamento do potencial das diferentes associações estudadas recentemente como fonte complementar ou substituta de fertilizantes químicos para a agricultura depende do entendimento das interações entre micro e macro-simbionte, que ainda é insipiente. Deste modo, torna-se imperativo identificar microrganismos importantes envolvidos nesse processo.

A introdução do meio semi-sólido como condição para o crescimento de diazotrófico dependente de fixação biológica de $\mathrm{N}_{2}$ (Döbereiner \& Day, 1976) em simbioses associativas, tem permitido grande avanço no isolamento e identificação de novas bactérias com relativa facilidade, embora sua comprovação definitiva como diazotrófico seja mais complexa. O princípio básico deste método é o crescimento seletivo desses organismos com baixa pressão parcial de oxigênio. Com base neste fato, 
procurou-se neste trabalho dar enfase ao isolamento a partir de seiva de plantas, especialmente, milho e sorgo.

A partir de amostras coletadas sob diferentes condições edafoclimáticas foram isolados, purificados e caracterizados, preliminarmente, através do aspecto de crescimento da cultura em meio semi-sólido com aparecimento de película típica, características morfológicas de colônias e de células observadas sob microscópio,e de atividade da nitrogenase. Foram obtidos 620 isolados de bactérias endofíticas e não endofíticas com características de diazotróficos, oriundas de solo, raizes lavadas e desinfestadas superficialmente, grãos imaturos de milho, estigma não emergido da espiga em formação e seiva de milho e de sorgo.

De acordo com os critérios recomendados por Döbereiner et al. (1995), que, além das demais características, incluem habilidade das estirpes de fixar $\mathrm{N}_{2}$ usando glicose como fonte de carbono e exigência de biotina como fator de crescimento, avaliou-se um grupo de 157 isolados de origens diversas (Apêndice 2). Embora esse grupo tenha sido escolhido ao acaso, encontrou-se somente as espécies $A$. lipoferum ou A.brasilense. Esses dados estão de acordo com Krieg \& Döbereiner (1986) que afirmaram ser a maioria das estirpes isoladas de gramíneas referida como $A$. lipoferum ou $A$. brasilense. Entretanto, vários isolados não se enquadaram nas espécies já identificadas e foram incluidas como gêneros não determinados. Döbereiner et al. (1993) considerou que, na maioria das simbioses associativas, ainda não se conhece o diazotrófico principal responsável pela fixação biológica. Observou-se, ainda, alta 
heterogeneidade morfológica de colônias entre os isolados (Figuras 1, 2, 3 e 4), indicando também a presença de outras bactérias associadas às plantas amostradas, além das espécies já descritas. Analisando-se alguns dados de acordo com o material de origem (Tabela 1), nota-se que foi possível isolar indistintamente $A$. lipoferum e A.brasilense de todos os órgãos da planta de milho, exceto de estígma, onde ocorreu só $A$. lipoferum. Entretanto, esses resultados talvez não representem colonização preferencial, visto que, torna-se possível enriquecer culturas e isolar microrganismos a partir de baixa densidade incial na amostra e, consequentemente, sem importância ecológica neste habitat específico.

Como se esperava, obtiveram-se vários isolados a partir de seiva de milho e de sorgo, dada a preferência destas bactérias por ácidos orgânicos, especialmente ácido málico, comum em seiva de plantas de milho (Butz \& Long, 1979; Tarrand et al., 1978). Döbereiner (1983) considerou o xilema como sítio adequado para a colonização e fixação de $\mathrm{N}_{2}$ em função da disponiblidade de fonte de carbono e também da presença de taxa reduzida de oxigênio, o que é essencial para a atividade da nitrogenase. Vários outros diazotróficos têm sido isolados de diferentes orgãos de diferentes espécies (Boddey et al., 1995 ) As tentativas de se isolar as outras espécies de bactérias fixadoras já descritas na literatura não apresentaram sucesso, indicando uma menor distribuição dessas bactérias nos materiais analisados. Estirpes de A. amazonense foram raramente obtidas a partir da seiva de milho, enquanto Herbaspirillum spp. ou Acetobacter diazotrophicus não foram isolados, mesmo utilizando os meios específicos (Döbereiner et al., 1995). 
Tabela 1 - Ocorrência de diferentes espécies de Azospirillum em algumas das amostras analisadas.

\begin{tabular}{lccc}
\hline \hline Amostragem & A. lipoferum & A. brasilense & A. amazonense \\
\hline Raiz de Sorgo & $5(9)$ & $4(9)$ & $2(9)$ \\
Raiz de Milho & $7(9)$ & $2(9)$ & $2(9)$ \\
Seiva de Milho & $4(9)$ & $5(9)$ & $1(9)$ \\
Seiva de Sorgo & $5(9)$ & $4(9)$ & $1(9)$ \\
Grãos de Milho & $6(9)$ & $1(9)$ & $0(9)$ \\
Estígma de Milho & $5(5)$ & $0(5)$ & $0(5)$ \\
Raiz de Capim Colonião & $3(5)$ & $2(5)$ & $1(5)$ \\
\hline \hline
\end{tabular}

Os números entre parênteses significam total de amostras analisadas. 

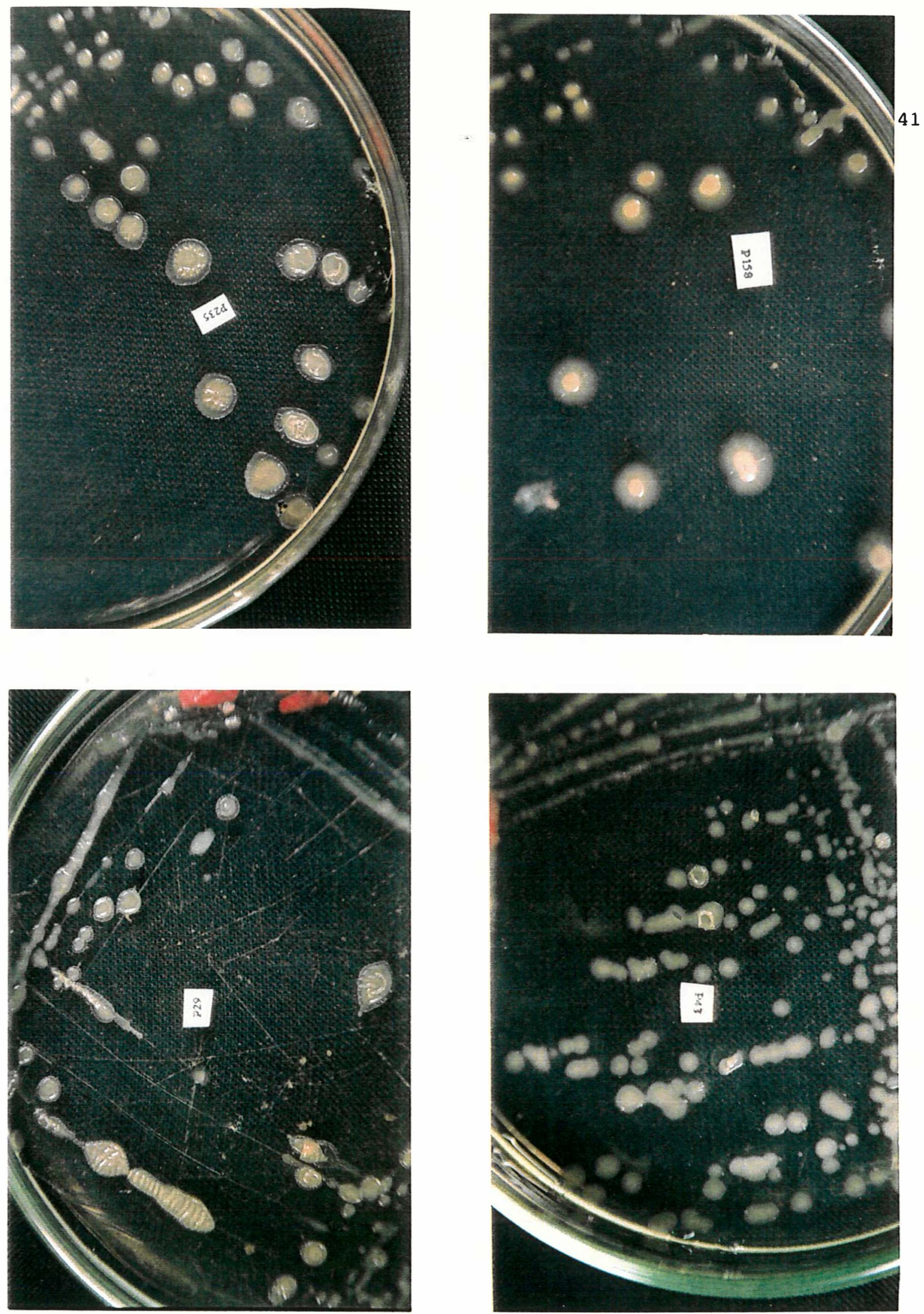

Figura 1 - Heterogeneidade morfológica de colônias de bactérias diazotróficas isoladas de gramíneas. 

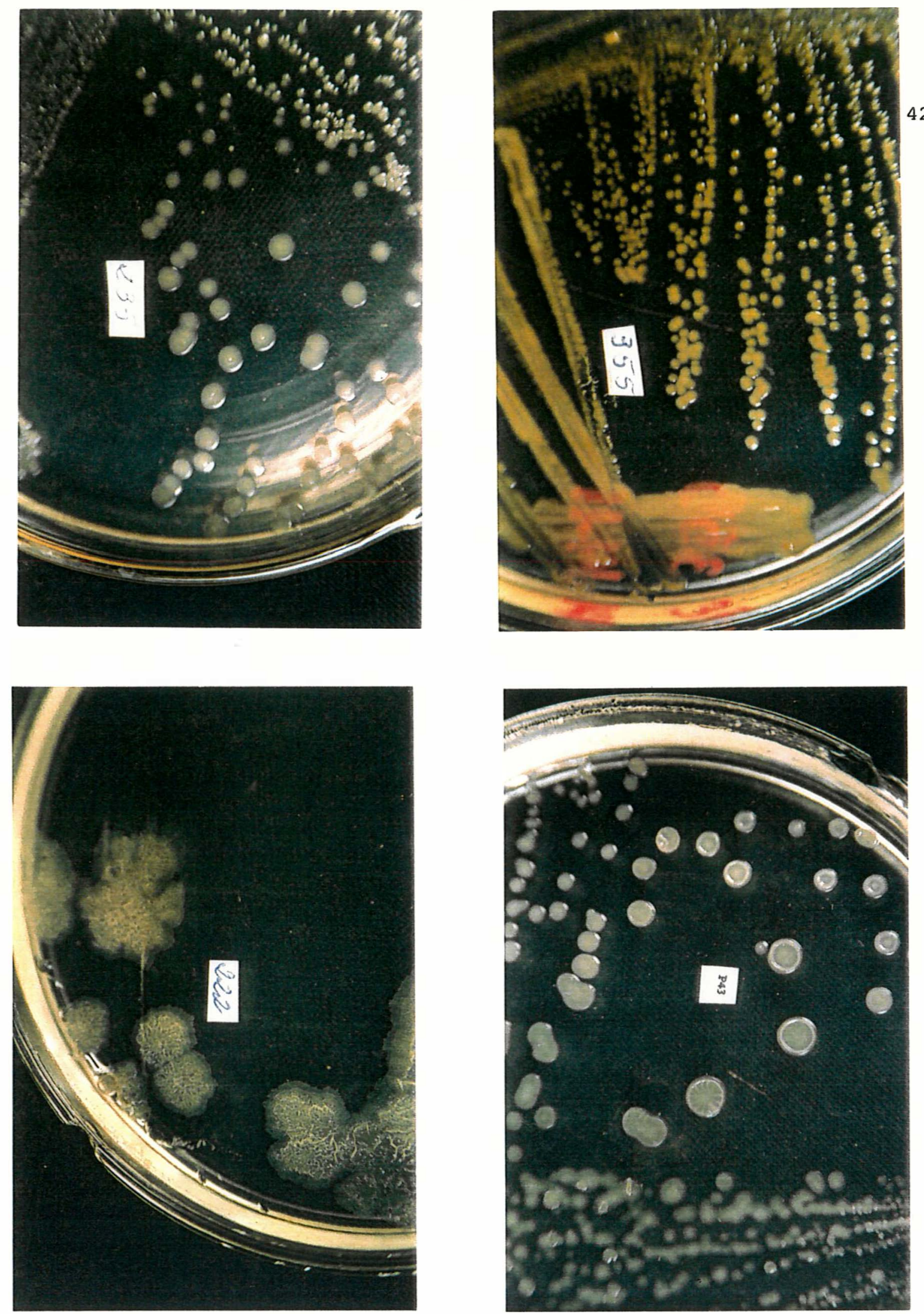

Figura 2 - Heterogeneidade morfológica de colônias de bactérias diazotróficas isoladas de gramíneas. 

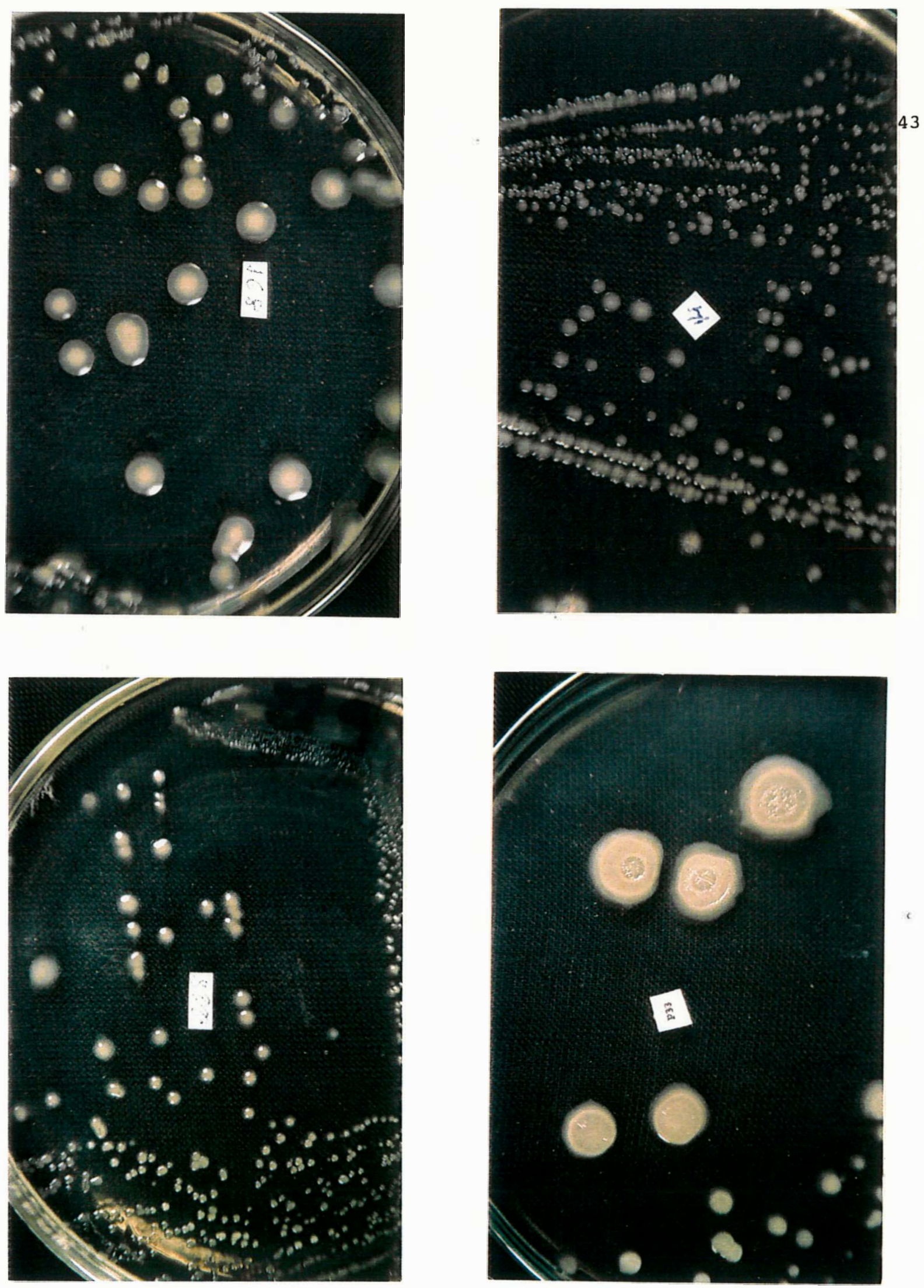

Figura 3 - Heterogeneidade morfológica de colônias de bactérias diazotróticas isoladas de gramíneas. 

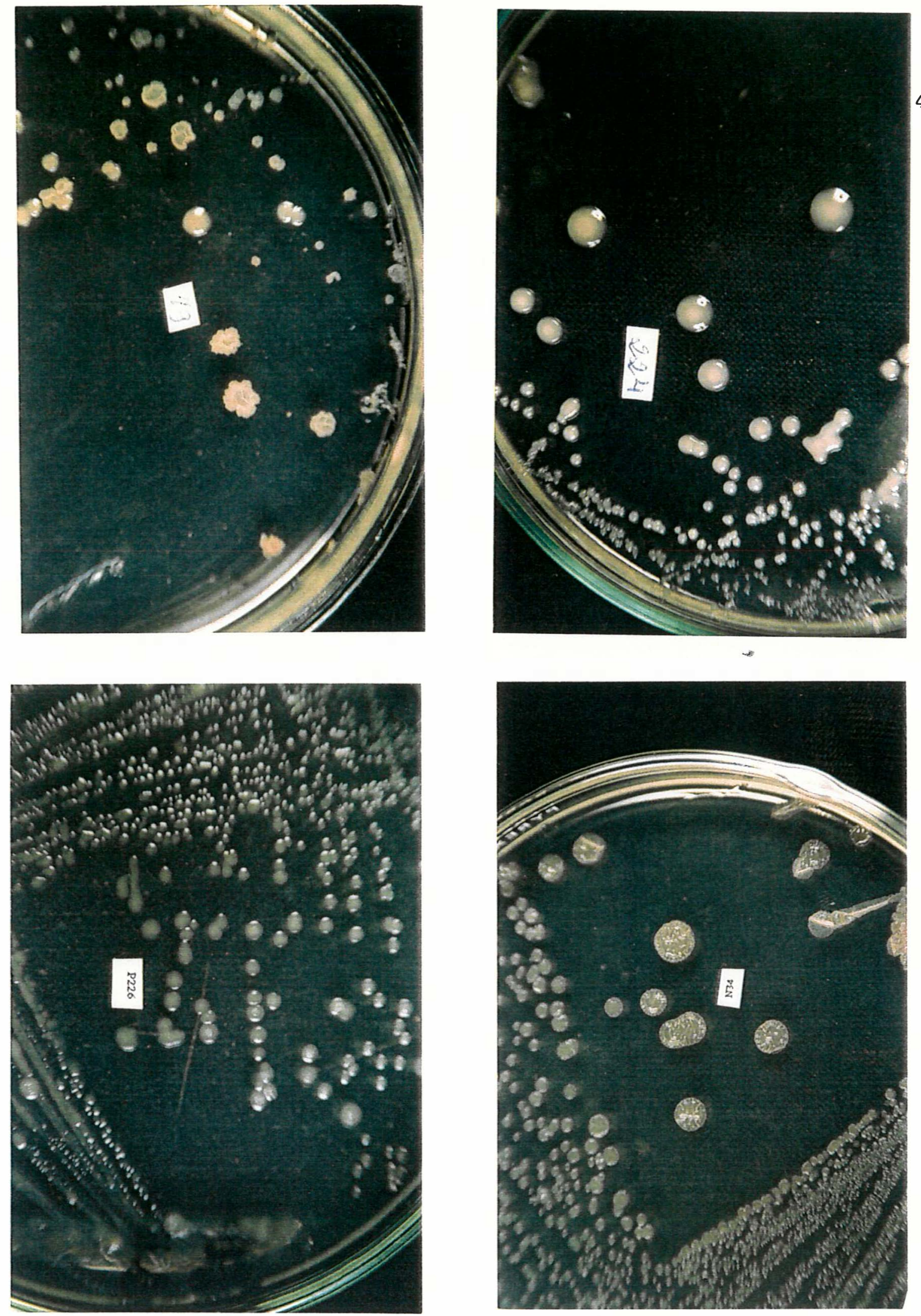

Figura 4 - Heterogeneidade morfológica de colônias de bactérias diazotróficas isoladas de gramíneas. 


\subsection{Caracterização serológica de bactérias fixadoras de $\mathbf{N}_{2}$}

A deteç̧ão de diazotróficos associados às gramíneas e cereais não apresenta dificuldades, mas, distinção entre os vários organismos que colonizam as rizosferas das plantas e definição de qual desempenha o papel mais importante nos processos intertivos com o hospedeiro, torna-se bastante complexo. Uma das dificuldades ocrre pela falta de metodologias precisas e que permitam a análise de elevado número de amostras. Os métodos serológicos têm sido utilizados com sucesso em diferentes circunstâncias.

Utilizaram-se os soros policlonais específicos, obtidos em coelho, contra as espécies de $A$. lipoferum, A.brasilense e A.amazonense para a caracterização serológica de parte dos isolados obtidos, através das técnicas de ELISA e DIBA. Através do teste ELISA, as reações recíprocas entre 157 diferentes isolados e as estirpes consideradas padrão mostram o relacionamento antigênico entre os isolados e possibilitaram estabelecer seis serogrupos distintos (Tabela 2, Figura 5). As reações positivas e com alta valor para a leitura de absorbância indicam proximidade antigênica, enquanto, leituras negativas ou com baixo valor de absorbância sugerem pouca similaridade serológica. 
Tabela 2 - Identificação numérica de bactérias diazotróficas, isoladas de origens diversas, agrupadas serologicamente através do teste ELISA.

\begin{tabular}{|c|c|c|c|c|c|}
\hline \multirow[t]{4}{*}{ Serogrupo 1} & 186 & 188 & 189 & 191 & 193 \\
\hline & 195.1 & 198 & 220 & 222 & 224.1 \\
\hline & 226 & 236 & 249 & 31.1 & 42.1 \\
\hline & 53 & 54 & 164.1 & 224 & \\
\hline \multirow[t]{9}{*}{ Serogrupo 2} & 177 & 177.1 & 195 & 200 & 201.1 \\
\hline & 215 & 215.1 & 216 & 217 & 219 \\
\hline & 223 & 223.1 & 225 & 228 & 230 \\
\hline & 234 & 235 & 237 & 238 & 240 \\
\hline & 243 & 245 & 245.1 & 253 & 13.1 \\
\hline & 15 & 15.1 & 22.2 & 29.1 & 31 \\
\hline & 33 & 34 & 43 & 43.1 & 97 \\
\hline & 98 & 125 & 125.1 & 132.1 & 157 \\
\hline & 164 & 165 & & & \\
\hline \multirow[t]{7}{*}{ Serogrupo 3} & 178,1 & 199 & 201 & 218 & 222,1 \\
\hline & 233 & 254 & 259 & 13 & 13,2 \\
\hline & 18 & 33,1 & 23 & 28 & 29 \\
\hline & 30 & 37 & 38 & 38,1 & 41 \\
\hline & 46 & 99 & 157,1 & 160 & 161 \\
\hline & 161,1 & 162,1 & 167 & 168 & 168,2 \\
\hline & 170 & 173 & 14 & 22 & 22,1 \\
\hline \multirow[t]{4}{*}{ Serogrupo 4} & 179,1 & 213 & 226,1 & 242 & 12 \\
\hline & 21 & 41,1 & 43,2 & 44 & 56 \\
\hline & 158 & 158,1 & 159,1 & 166 & 169 \\
\hline & 171 & 172 & 176 & & \\
\hline \multirow[t]{10}{*}{ Serogrupo 5} & 174 & 175,1 & 176,1 & 178 & 182 \\
\hline & 187 & 189,1 & 192 & 194 & 196 \\
\hline & 197 & 215,2 & 221 & 229 & 236,1 \\
\hline & 239 & 241 & 244 & 246 & 248 \\
\hline & 250 & 251 & 252 & 255 & 257 \\
\hline & 2 & 20 & 20,1 & 20,2 & 30,1 \\
\hline & 36 & 42 & 45 & 45,1 & 71 \\
\hline & 71 & 79 & 95 & 95,1 & 101 \\
\hline & 101,1 & 119 & 132 & 159 & 168,1 \\
\hline & 175 & 256 & 103 & & \\
\hline Serogrupo 6 & 214 & 227 & & & \\
\hline
\end{tabular}




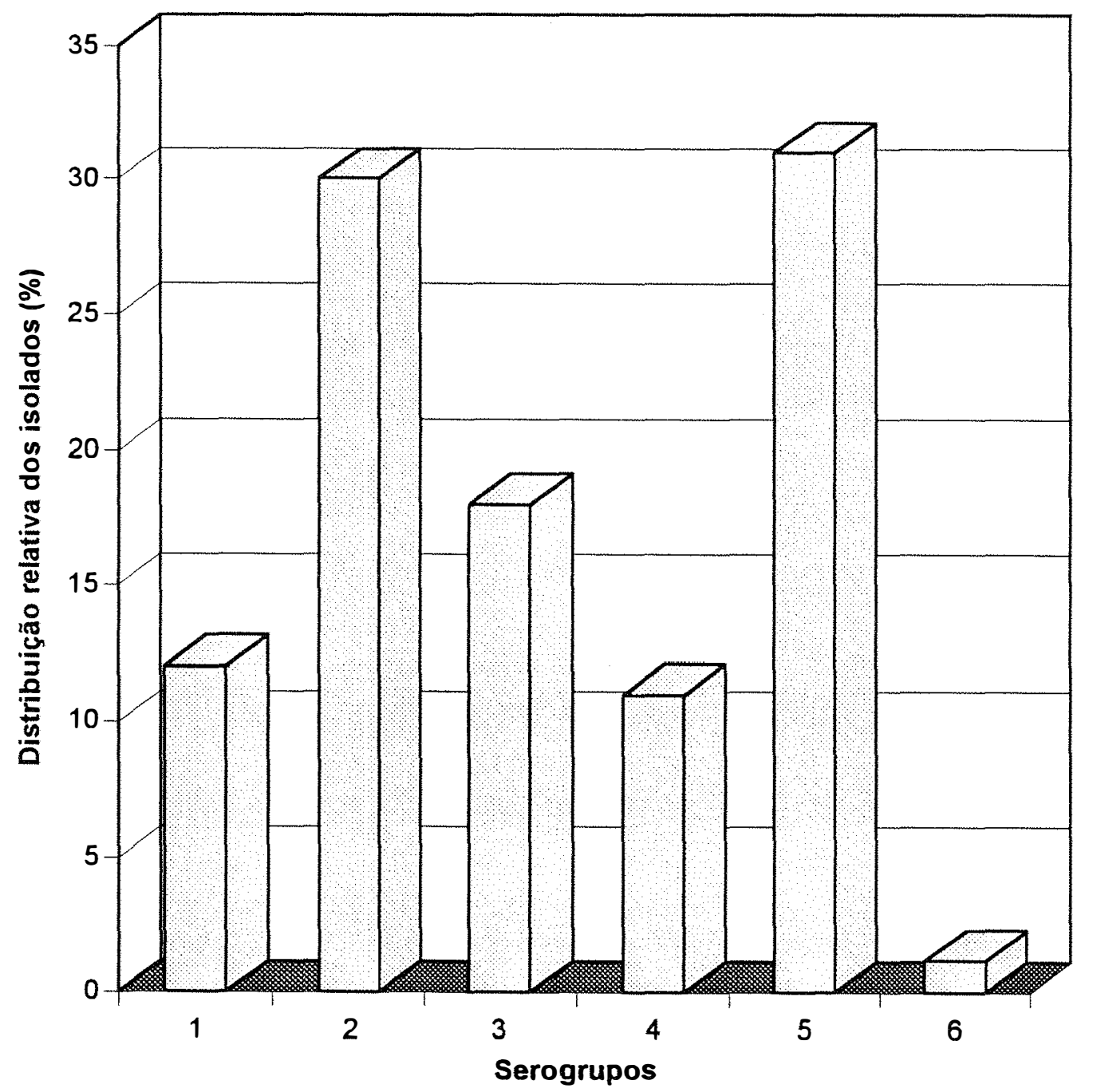

47

Figura 5 - Classificação serológica de 157 isolados de bactérias diazotróficas obtidos de diversas origens, através do teste ELISA.

Serogrupo 1 - Reação positiva dos isolados com o antissoro contra $A$. lipoferum.

Serogrupo 2 - Reação positiva dos isolados com o antissoro contra $A$. brasilense.

Serogrupo 3 - Reação positiva dos isolados com os antissoros contra $A$. lipoferum e $A$. brasilense.

Serogrupo 4 - Reação positiva dos isolados com os antissoros contra $A$. lipoferum, $A$. brasilense e $A$. amazonense.

Serogrupo 5 - Reação negativa dos isolados com os antissoros contra $A$. lipoferum, $A$. brasilense e $A$. amazonense.

Serogrupo 6 - Reação positiva dos isolados com os antissoros contra $A$. lipoferum e $A$. amazonense. 
A literatura disponível sobre estudos imunológicos em Azospirillum é limitada, mesmo com anticorpos policlonais. E, nestes casos, ocorrem reações cruzadas com alta frequência, dada a existência de antígenos comuns entre e dentre este gênero de bactéria (Dazzo \& Milam, 1976; De-Polli et al., 1980). Entretanto, a introdução de metodologias mais modernas, com as técnicas ELISA e DIBA, permitiu melhorar a eficiência dos testes serológicos com antissoros convencionais. Neste trabalho, notou-se acentuada diversidade serológica entre os 157 isolados testados, tomados ao acaso, sendo que em torno de $12 \%$ dos isolados reagiram especificamente com o antissoro produzido contra $A$. lipoferum e $24 \%$ reagiram com o de $A$. brasilense, além dos isolados que apresentarm antígenos comuns com duas ou mais espécies. Uma estirpe mutante de Azospirillum, $A$. brasilense $C d$ tem sido quantificado especificamente na rizosfera de vários cereais (Levanony et al., 1987). Vale salientar o fato de aproximadamente $32 \%$ dos isolados nâo terem reagidos com nenhuma das espécies testadas como padrão e, consequentemnte, não apresentam antígenos comuns com estas bactérias, indicando que tais bactérias podem incluir microrganismos ainda desconhecidos, mas, importantes nas interações com as respectivas plantas hospedeiras.

Esta distribuição das estirpes não discrimina, entretanto, as reações fracamente positivas das fortemente positivas. Mas, permite, com segurança, a classificação dos isolados nos respectivos grupos serológicos, pois a amostra somente foi considerada positiva quando apresentou valores de absorbância acima de 1,5 vezes o do controle, no teste ELISA. Em geral, houve estreita concordância entre os grupos 
definidos serologicamente a identificação prévia efetuada com base nas observações microscópicas, morfológicas e nutricionais, indicando a validade das metodologias utilizadas. Consequentemente, estas técnicas serológicas podem desempenhar papel importante nas pesquisas relacionadas às relações associativas.

Em relação ao nível de sensibilidade dos testes serológicos utilizados, comparando-se as técnicas ELISA e DIBA, obteve-se o limite para detecção de Azospirillum em suspensão de células, através de reações recíprocas entre $A$. lipoferum, A. brasilense $e$ A. amazonense. Os resultados apresentados na Tabela 3 e Figura 6 mostram, além do limite de deteç̧ão, a especificidade de reação dos antígenos bacterianos para os antissoros homólogos. Utilizando-se a concentração do antígeno em torno de $10^{7}$ de células, torna-se possível discriminar cada espécie de Azospirillum em suspensão. Comparando-se os valores apresentados, nota-se que as técnicas ELISA e DIBA apresentaram o mesmo nível de sensibilidade para detecção de células, isto é, em torno de $10^{5}$ a $10^{6}$ células viáveis por $\mathrm{ml}$, quando se considera os antígenos e antissoros homólogos, dependendo da espécie de bactéria. Esses valores estão um pouco acima daqueles mencionados por Levanony (1987) em teste ELISA, $10^{4}$ células viáveis por ml, provavelmente devido à bactéria ou ao método de contagem utilizados.

Independente dos métodos empregados, a estirpe 59b, representante da espécie A.lipoferum, parece mais reativa que a espécie A.brasilense sp7. Ahmad et al. (1981), através do exame de diversidade serológica entre isolados de rizóbio, concluíram que a reatividade em ELISA estava correlacionada com a morfologia da colônia. Estirpes da bactéria com colônias secas pareciam mais reativas que as de colônias úmidas. 
Tabela 3 - Limite de deteç̧ão de Azospirillum spp. em suspensão de células e especificidade dos antissoros, determinados através do teste ELISA.

\begin{tabular}{|c|c|c|c|c|}
\hline \multirow[b]{2}{*}{ Antígenos } & \multirow{2}{*}{$\begin{array}{l}\text { Concentração } \\
n^{0} \text { células/ml }\end{array}$} & \multicolumn{3}{|c|}{ Antissoros } \\
\hline & & $59 \mathrm{~b}$ & sp7 & A14 \\
\hline \multirow[t]{5}{*}{ Ag. A. lipoferum 59b } & $10^{8}$ & 0,520 & 0,375 & 0,060 \\
\hline & $10^{7}$ & 0,475 & 0,000 & 0,000 \\
\hline & $10^{6}$ & 0,358 & 0,000 & 0,000 \\
\hline & $10^{5}$ & 0,028 & 0,000 & 0,000 \\
\hline & $10^{4}$ & 0,000 & 0,000 & 0,000 \\
\hline \multirow[t]{5}{*}{ Ag. A. brasilense $\mathrm{sp} 7$} & $10^{8}$ & 0,462 & 0,401 & 0,000 \\
\hline & $10^{7}$ & 0,198 & 0,386 & 0,000 \\
\hline & $10^{6}$ & 0,000 & 0,095 & 0,000 \\
\hline & $10^{5}$ & 0,000 & 0,000 & 0,000 \\
\hline & $10^{4}$ & 0,000 & 0,000 & 0,000 \\
\hline
\end{tabular}

$\mathrm{A} 14=$ A. amazonense. 


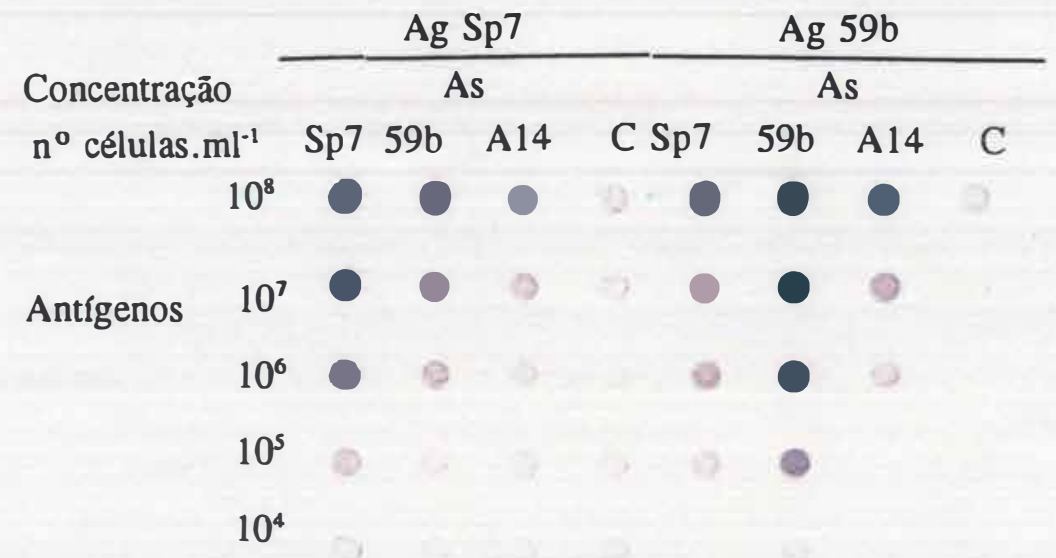

Figura 6 Limite de detecção de Azospirillum spp. em suspensão de células e especificidade dos antissoros, determinados em reações cruzadas entre os diferentes antígenos ( $\mathrm{Ag})$ e antissoros (As), através do teste DIBA. $\mathrm{Sp} 7=A$. brasilense $; 59 \mathrm{~b}=A$. lipoferum; $\mathrm{A} 14=A$. amazonense $\mathrm{C}=$ controle positivo Spot colorido $=$ reação positiva Spot rosa pálido ou sem cor $=$ reação negativa 


\subsection{Ocorrência natural de endófitos diazotróficos em milho e sorgo}

A metodologia básica, recomendada para o isolamento de bactérias fixadoras de nitrogênio, indica que a fixação biológica em simbiose associativa ocorre onde a pressão parcial de oxigênio for reduzida e onde houver disponibilidade de fonte de carbono (Döbereiner et al., 1995). Como ainda não se conhece o principal organismo envolvido na fixação biológica associada à cultura do milho, justifica-se o interesse nessa cultura.

Dentre as amostras utilizadas para o isolamento de diazotróficos ,utilizouse a seiva de milho e de sorgo. Notou-se, desde o início da pesquisa, que existia certa facilidade para a obtenção de bactérias com determinadas características, que foram em seguida, identificadas como Azospirillum lipoferum. Esta bactéria ocorre associada a diferentes plantas hospedeira, tipo de solo e de clima (Döbereiner \& Pedrosa,1987). Entretanto, outras bactérias foram também isoladas e purificadas, embora em número bem mais restrito do que a partir da rizosfera, onde se encontrou maior diversidade de microrganismos diazotróficos.

Uma vez ajustada a concentração adequada de antígeno e de antissoro para o teste ELISA e para DIBA, avaliou-se preliminarmente a ocorrência de serogrupos definidos previamente em diferentes amostras. Inicialmente em número reduzido de amostras de seiva, observou-se somente o serogrupo com antígeno comum à espécie A. lipoferum. Numa outra etapa, avaliaram-se 28 genótipos com reações contra os 
antissoros de A.lipoferum de $A$. brasilense, através da técnica DIBA. Os dados obtidos estão apresentados na Figura 7. Observou-se uma reação altamente específica com A. lipoferum, indicando uma predominãncia quase absoluta desta espécie em seiva de plantas de milho. Isto não significa que exista somente esta bactéria nestas plantas, mas sugere uma população mais elevada desta espécie, considerando que a sensibilidade do método está em torno de $10^{5}$ a $10^{6}$ células viáveis por $\mathrm{ml}$, como mostrado para ELISA e DIBA (Tabela 3, Figura 6).

Em outro ensaio, utilizou-se o teste ELISA para se avaliarem de 63 genótipos de milho e 10 de sorgo. Os dados demonstraram a ocorrência de $85 \%$ de reações positvas com $A$ lipoferum e de $6 \%$ de positivas com $A$. brasilense (Figura 8), confirmando a predominância do primeiro grupo. Os dados mostraram desde reações fracamente positivas a fortemente positivas, indicando o efeito de genótipos sobre a associação milho-diazotróficos. As variações nos valores de $\mathrm{pH}$ e na composição de macro e micronutrientes na seiva destas plantas (Tabela 4), provavelmente, explicam parte das diferenças encontradas entre genótipos.

Outros endófitos têm sido obtidos a partir de tecidos de diferentes plantas, à semelhança de Acetobacter diazotrophicus em cana de açúcar (Döbereiner et al., (1993). Esses dados são consubstanciados pelas descobertas de Pereira et al., (1988) que encontraram $70 \%$ da população de diazotróficos estabelecidos em colmo de sorgo inoculado com A. lipoferum como inoculante. As primeiras evidências de especificidade entre diazotróficos e cereais foram relatadas por Baldani et al. (1986). Estirpes isoladas 


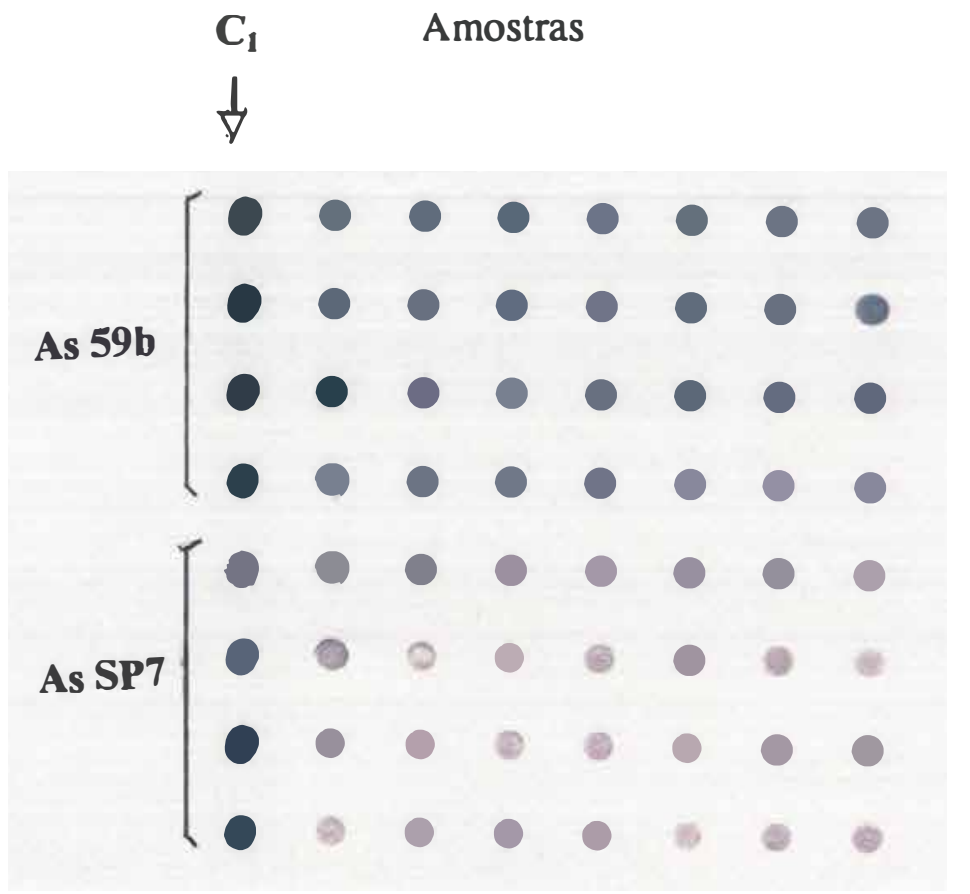

Figura 7 Ocorrência natural relativa dos serogrupos $A$. lipoferum (59b) e $A$. brasilense (Sp7) em amostra de seiva de 28 genótipos de milho cultivados no campo, sem inoculação artificial, determinada através do teste DIBA. $\mathrm{C}=$ controle positivo Spot colorido $=$ reação positiva Spot rosa pálido ou sem cor $=$ reação negativa 
de plantas $C_{4}$ são mais atraidas por malato enquanto as de $C_{3}$ são atraidas por oxalato (Reinhold et al., 1985). A presença de ácido málico em seiva de milho tem sido considerada como fator responsável pela maior afinidade Azospirillum - milho. Mas, faltava uma metodologia para esclarecer esta especificidade, que ainda é controvertida. Bashan \& Levanony (1990) discutem exemplos onde não se demonstra a especificidade entre Azospirillum e gramíneas. A consistência dos dados apresentados indica alto grau de colonização natural seletiva de $A$. lipoferum em milho e sorgo.

\subsection{Caracterização bioquímica de isolados de diazotróficos}

Existem rotinas bem estabelecidas e relativamente simples para a identificação de diazotróficos (Döbereiner et al., 1995), principalmente baseadas em fontes de carbono específicas. As fontes de carbono preferidas para todas as espécies de Azospirillum são ácidos orgânicos como succinato, malato e lactato (Okon et al., 1976, Tarrand et al., 1978; Reinhold et al., 1987). Entretanto, existem diferenças interespecíficas no padrão de uso de carboidratos. Sabe-se, por exemplo, que $A$. lipoferum cresce em glicose enquanto $A$. brasilense não se multiplica nesse meio, embora possua via enzimática catabólica para tal (Gobel \& Krieg, 1984). Mas, o nível de dificuldade aumenta à medida que cresce o número de isolados a serem trabalhados. 


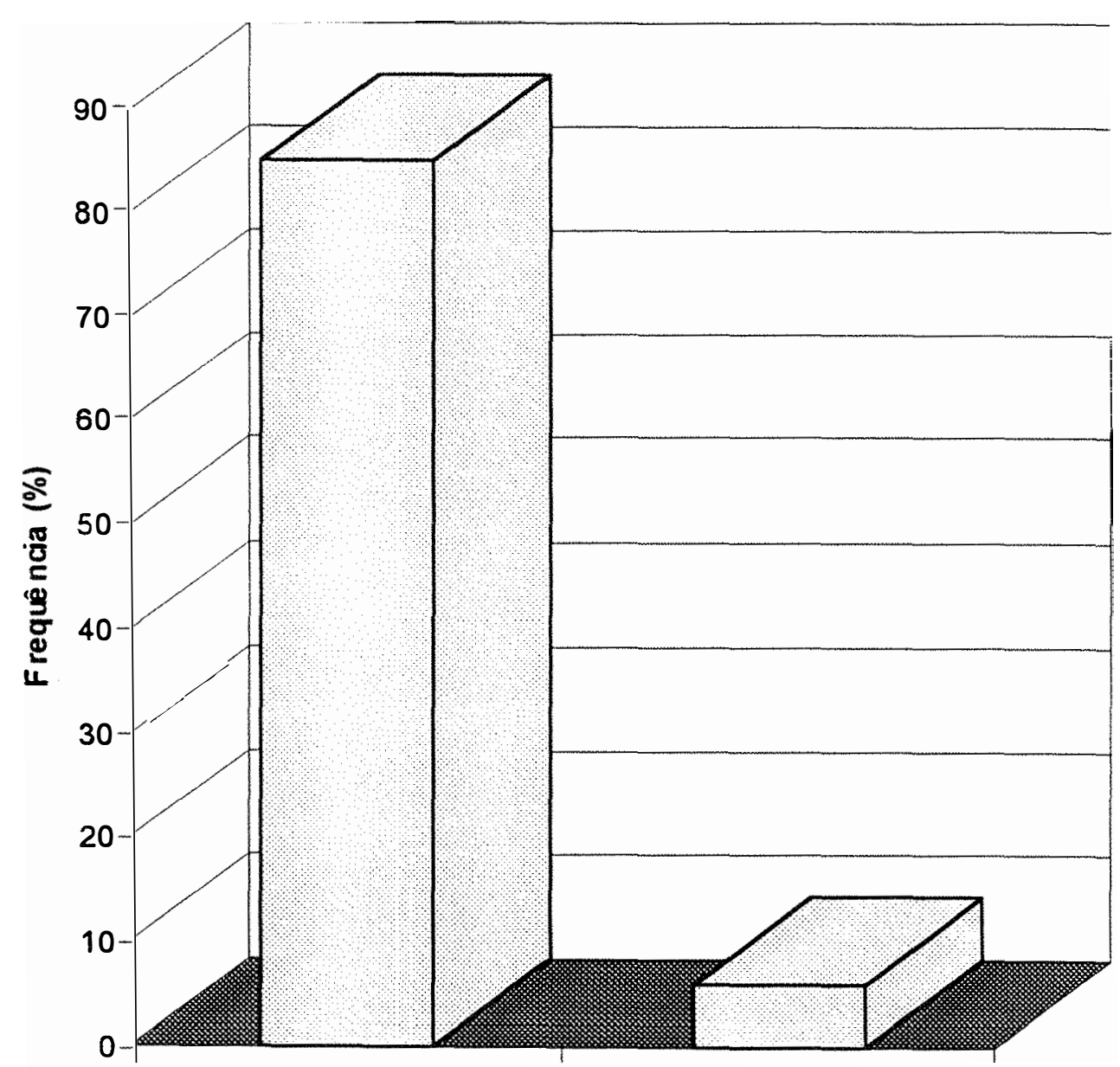

56

A. lipoferum

A. brasilense

Figura 8 - Ocorrência natural dos serogrupos A.lipoferum e A. brasilense, em amostras de seiva de 63 genótipos de milho e 10 de sorgo, cultivados no campo sem inoculação artificial, no estádio de florescimento, determinada através do teste ELISA. 
Tabela 4 - Valores de $\mathrm{pH}$ e teores de alguns macro e micronutrientes em seiva de 12 genótipos de milho, cultivados no campo sem inoculação artificial, no estádio de florescimento ${ }^{1}$.

\begin{tabular}{|c|c|c|c|c|c|c|c|c|}
\hline \multirow[b]{2}{*}{ genótipos } & \multirow[b]{2}{*}{$\mathrm{pH}$} & \multicolumn{4}{|c|}{ macro } & \multicolumn{3}{|c|}{ micro } \\
\hline & & $P$ & $\bar{K}$ & $\mathrm{Ca}$ & $\mathrm{Mg}$ & B & $\mathrm{Zn}$ & Mo \\
\hline & & $\ldots .$. & & $\cdots$ & $\mathrm{g}^{-1} .$. & & & \\
\hline 3 & 6,25 & 54,28 & 417,14 & 50,18 & 30,95 & 9,84 & 0,699 & 0,178 \\
\hline 5 & 6,26 & 13,13 & 116,66 & 17,52 & 9,87 & 10,20 & 0,000 & 0,132 \\
\hline 11 & 6,46 & 7,10 & 485,29 & 17,52 & 41,35 & 9,69 & 0,268 & 0,314 \\
\hline 12 & 6,38 & 69,12 & 687,74 & 97,39 & 52,16 & 9,61 & 0,490 & 0,483 \\
\hline 14 & 6,27 & 50,52 & 243,83 & 98,12 & 29,98 & 9,68 & 0,000 & 0,396 \\
\hline 15 & 6,10 & 38,22 & 400,47 & 35,63 & 23,46 & 9,53 & 0,163 & 0,371 \\
\hline 16 & 5,98 & 52,81 & 349,41 & 40,97 & 16,80 & 9,39 & 0,000 & 0,321 \\
\hline 17 & 6,28 & 28,59 & 206,93 & 47,04 & 14,72 & 9,31 & 0,000 & 0,187 \\
\hline 19 & 5,80 & 51,95 & 312,30 & 28,10 & 26,92 & 9,32 & 0,000 & 0,170 \\
\hline 20 & 5,93 & 44,32 & 347,94 & 42,12 & 25,40 & 9,55 & 0,059 & 0,076 \\
\hline 27 & 6,45 & 32,22 & 212,48 & 38,77 & 20,96 & 9,10 & 0,000 & 0,088 \\
\hline 28 & 6,67 & 31,68 & 192,04 & 48,40 & 26,37 & 9,20 & 0,117 & 0,110 \\
\hline
\end{tabular}

${ }^{1}$ Cada amostra foi constituída de uma mistura de seiva de três plantas.

Procurou-se avaliar a utilização do Kit API 20E como instrumento de diferenciação de isolados e não como meio de identificação, poís não sendo este específico para os organismos de interesse, seu uso torna-se complexo (Döbereiner, 1989). Por outro lado, kit adequado tem sido usado para identificar outras bactérias fixadoras de $\mathrm{N}_{2}$ como Bacillus azotofixans (Seldin \& Penido, 1986). Dos 27 isolados analisados, incluindo uma estirpe de $A$. lipofenum e uma de $A$. brasilense, não foi possível a identificação, com base nos testes contidos no kit utilizado. Entretanto, as 
espécies de Azospirillum são facilmente eliminadas, somente com base no teste de glicose, que é a fonte de carbono chave para a distinção entre estas espécies (Döbereiner et al., 1995). Como as bactérias do gênero Azospirillum utilizam relativamente poucos polissacarídeos (Tarrand.et al., 1978), selecionando-se apenas 5 carboidratos foi possível demonstrar variabilidade bioquímica entre os isolados testados (Tabela 5). Os dados bioquímicos confirmam a ampla diversidade de bactérias que podem ser isoladas a partir de gramíneas com características aparente de Azospirillum, mas com propriedades bioquímicas, serológicas e morfológicas totalmente distintas e, certamente, desepenhando algum papel na ciclagem de $\mathrm{N}$ nos diferentes ecossistemas.

\subsection{Respostas de genótipos de milho à inoculação com Azospirillum spp.}

\subsubsection{Efeito da inoculação com Azospirillum spp. sobre a morfologia do sistema radicular, crescimento e acúmulo de nutrientes em milho}

Os efeitos da inoculação e dos genótipos sobre o crescimento e a incorporação de macronutrientes e micronutrientes na parte aérea das plantas de milho cultivadas em condições de disponibilidade limitada de nitrogênio, podem ser verificados quando se compara os dados apresentados nas Tabelas 6, 7, 8, 9 e 10. Observam-se efeitos significativos do genótipo da planta sobre o acúmulo de matéria seca na parte 
Tabela 5 - Diferenciação bioquímica de bactérias diazotróficas isoladas de gramíneas, através do kit API 20E.

\begin{tabular}{lccccc}
\hline \hline Ident. isolados & gelatina & manose & sorbitol & amidalina & glicose \\
\hline A.lipoferum & - & - & - & - & + \\
A.brasiliense & - & - & - & - & - \\
Isolado 1 & + & - & - & - & - \\
Isolado 2 & - & + & - & - & - \\
Isolado 3 & - & - & - & - & - \\
Isolado 4 & + & - & - & - & - \\
Isolado 5 & + & + & + & + & + \\
Isolado 6 & + & + & + & + & - \\
Isolado 7 & - & - & - & - & - \\
Isolado 8 & - & - & - & - & - \\
Isolado 9 & + & - & - & - & - \\
Isolado 10 & - & - & - & - & - \\
Isolado 11 & + & - & - & - & - \\
Isolado 12 & - & + & - & - & + \\
Isolado 13 & - & - & - & - & - \\
Isolado 14 & - & - & - & - & - \\
Isolado 15 & + & + & + & + & + \\
Isolado 16 & + & - & - & + & - \\
Isolado 17 & - & - & - & - & + \\
Isolado 18 & - & + & - & - & - \\
Isolado 19 & + & + & + & - & - \\
Isolado 20 & - & - & - & - & - \\
Isolado 21 & - & - & - & - & + \\
Isolado 22 & - & - & - & - & + \\
Isolado 23 & + & - & - & - & - \\
Isolado 24 & - & - & - & - & - \\
Isolado 25 & + & - & - & - & + \\
\hline \hline
\end{tabular}

$(+)=$ Reação positiva

$(-)=$ Reação negativa 
aérea e dos macronutrientes analisados, independente da presença das bactérias inoculadas. O cultivar CMS 36 apresentou maior crescimento e acúmulo de nutrientes, sendo uma população promissora para ser explorada como fontes de genótipos superiores para fixação biológica de $\mathrm{N}_{2}$.

Verifica-se que a produção de massa seca da parte aérea das plantas não foi alterada pela inoculação. Contudo, as concentrações dos macronutrientes, exceto as de cálcio e nitrogênio, foram aumentadas pela inoculação (Tabela 7). Embora tenha ocorrido um acréscimo de $17 \%$ no teor deste último.

Por outro lado, os conteúdos de nitrogênio, fósforo, potássio e enxofre foram significativamente mais elevados nas plantas inoculadas em relação ao controle, plantas não inoculadas, independente dos genótipos (Tabela 8). Este aumento só não foi significativo para o genótipo BR 405, que foi afetado negativamente pela inoculação. Em relação ao cálcio, não se observou efeito da inoculação. De modo similar, houve um aumento no conteúdo de zinco na parte aérea das plantas na presença da inoculação com Azospirillum. Os conteúdos dos demais e os teores não foram influenciados por este tratamento (Tabelas 9 e 10). Diferente do observado com a parte aérea, a inoculação não resultou em aumentos significativos sobre as variáveis medidas no sistema radicular, como massa seca e número totais e parciais de intersecções e acúmulo de macronutrientes, exceto teor de nitrogênio (Tabelas $6,11,12,15)$. Pelo contrário, a inoculação influenciou negativamente a massa seca radicular, embora em níveis não significativos. Enquanto mostrou efeitos positivos em relação aos teores e conteúdos de molibdênio e 
Tabela 6 - Acúmulo de matéria seca (g/planta) na parte aérea e nas raízes de genótipos de milho cultivados em solução nutritiva, inoculados e não inoculados com uma mistura de estirpes homólogas de $A$. lipoferum e A.brasilense, 20 dias após a germinação. Médias de três repetições.

\begin{tabular}{|c|c|c|c|c|c|c|}
\hline \multirow[b]{2}{*}{ Inoculação } & \multicolumn{5}{|c|}{ Genótipos } & \multirow{3}{*}{ Médias } \\
\hline & CMS 13 & CMS 36 & BR.451 & S.ELITE & CMS 51 & \\
\hline & \multicolumn{5}{|c|}{ Parte aérea } & \\
\hline Com & 0,286 & 0,335 & 0,224 & 0,259 & 0,265 & $0,274 \mathrm{~A}$ \\
\hline Sem & 0,304 & 0,322 & 0,278 & 0,166 & 0,230 & $0,260 \mathrm{~A}$ \\
\hline \multirow[t]{2}{*}{ Médias } & $0,295 \mathrm{ab}$ & $0,328 \mathrm{a}$ & $0,251 \mathrm{bc}$ & $0,212 \mathrm{c}$ & $0,248 \mathrm{bc}$ & \\
\hline & \multicolumn{5}{|c|}{ Raízes } & \\
\hline Com & 0,258 & 0,240 & 0,236 & 0,152 & 0,250 & $0,218 \mathrm{~A}$ \\
\hline Sem & 0,277 & 0,300 & 0,182 & 0,197 & 0,230 & $0,237 \mathrm{~A}$ \\
\hline Médias & $0,267 \mathrm{a}$ & $0,270 \mathrm{a}$ & $0,209 \mathrm{~b}$ & $0,175 \mathrm{~b}$ & $0,218 \mathrm{ab}$ & \\
\hline
\end{tabular}

Nas linhas, as médias seguidas pela mesma letra minúscula e, nas colunas, da mesma letra maiúscula não diferem entre si $(\mathrm{P}<0,05)$ pelo teste de Duncan. 
Tabela 7 - Teores médios de macronutrientes $\left(\mathrm{g} \mathrm{kg}^{-1}\right)$ na parte aérea de genótipos milho cultivados em solução nutritiva, inoculados e não inoculados com uma mistura de estirpes homólogas de A.lipoferum e A.brasilense, 20 dias após a germinação. Médias de três repetições.

\begin{tabular}{|c|c|c|c|c|c|c|}
\hline \multirow[b]{2}{*}{ Inoculação } & \multicolumn{5}{|c|}{ Genótipos } & \multirow[b]{2}{*}{ Médias } \\
\hline & CMS 13 & CMS 36 & BR 451 & S.ELITE & CMS 51 & \\
\hline & \multicolumn{5}{|c|}{$\mathrm{N}$} & \\
\hline Com & 25,53 & 23,67 & 19,77 & 22,10 & 22,50 & $22,71 \mathrm{~A}$ \\
\hline Sem & 20,00 & 18,47 & 18,00 & 21,00 & 19,43 & $19,38 \mathrm{~A}$ \\
\hline \multirow[t]{2}{*}{ Médias } & 22,77 a & $21,07 \mathrm{a}$ & $18,88 \mathrm{a}$ & $21,55 \mathrm{a}$ & 20,97 a & \\
\hline & \multicolumn{5}{|c|}{$P$} & \multirow[b]{2}{*}{$10,95 \mathrm{~A}$} \\
\hline Com & 9,77 & 12,00 & 11,03 & 10,77 & 11,17 & \\
\hline Sem & 8,00 & 9,60 & 8,48 & 8,97 & 8,83 & $8,78 \mathrm{~B}$ \\
\hline \multirow[t]{2}{*}{ Médias } & $8,89 \mathrm{a}$ & $10,80 \mathrm{a}$ & $9,75 \mathrm{a}$ & $9,87 \mathrm{a}$ & $10,00 \mathrm{a}$ & \\
\hline & \multicolumn{5}{|c|}{$\bar{K}$} & \\
\hline Com & 73,23 & 71,80 & 63,03 & 61,53 & 62,23 & $67,17 \mathrm{~A}$ \\
\hline Sem & 49,83 & 63,60 & 56,40 & 52,90 & 54,73 & $55,49 \mathrm{~B}$ \\
\hline \multirow[t]{2}{*}{ Médias } & $61,53 \mathrm{a}$ & $67,70 \mathrm{a}$ & 59,72 a & 57,22 a & 60,48 a & \\
\hline & \multicolumn{5}{|c|}{$\mathrm{Ca}$} & \\
\hline Com & 9,97 & 10,20 & 9,6 & 10,03 & 10,00 & $9,96 \mathrm{~A}$ \\
\hline Sem & 9,00 & 10,47 & 8,83 & 10,70 & 9,57 & $9,71 \mathrm{~A}$ \\
\hline \multirow[t]{2}{*}{ Médias } & $9,48 \mathrm{a}$ & $10,33 \mathrm{a}$ & $9,22 \mathrm{a}$ & $10,37 \mathrm{a}$ & $0,978 \mathrm{a}$ & \\
\hline & \multicolumn{5}{|c|}{$\overline{M g}$} & \\
\hline Com & 5,23 & 5,50 & 5,40 & 4,97 & 5,47 & $5,31 \mathrm{~A}$ \\
\hline Sem & 4,62 & 5,33 & 4,60 & 4,83 & 4,87 & $4,86 \mathrm{~B}$ \\
\hline \multirow[t]{2}{*}{ Médias } & $4,92 \mathrm{a}$ & $5,14 \mathrm{a}$ & $5,04 \mathrm{a}$ & $4,90 \mathrm{a}$ & $5,17 \mathrm{a}$ & \\
\hline & \multicolumn{5}{|c|}{$S$} & \\
\hline Com & 1,87 & 1,77 & 1,93 & 1,83 & 2,53 & 1,99A \\
\hline Sem & 1,40 & 1,67 & 1,77 & 1,80 & 1,67 & $1,66 \mathrm{~B}$ \\
\hline Médias & $1,63 \mathrm{a}$ & $1,72 \mathrm{a}$ & $1,85 \mathrm{a}$ & $1,82 \mathrm{a}$ & $2,10 \mathrm{a}$ & \\
\hline
\end{tabular}

Nas linhas, as médias seguidas pela mesma letra minúscula e, nas colunas, da mesma letra maiúscula não diferem entre si $(\mathrm{P}<0,05)$ pelo teste de Duncan. 
Tabela 8 - Conteúdos médios de macronutrientes (mg/planta) na parte aérea de genótipos de milho cultivados em solução nutritiva, inoculados e não inoculados com uma mistura de estirpes homólogas de A.lipoferum e A. brasilense, 20 dias após a germinação. Médias de três repetições.

\begin{tabular}{|c|c|c|c|c|c|c|}
\hline \multirow[b]{2}{*}{ Inoculação } & \multicolumn{5}{|c|}{ Genótipo } & \multirow[b]{2}{*}{ Médias } \\
\hline & CMS 13 & CMS 36 & BR 451 & S. ELITE & CMS 51 & \\
\hline & \multicolumn{5}{|c|}{$\mathrm{N}$} & \\
\hline Com & 7,29 & 7,78 & 4,55 & 5,68 & 5,97 & $6,26 \mathrm{~A}$ \\
\hline Sem & 6,08 & 5,94 & 5,02 & 3,47 & 4,43 & $4,99 \mathrm{~B}$ \\
\hline \multirow[t]{2}{*}{ Médias } & $6,69 \mathrm{a}$ & $6,87 \mathrm{a}$ & $4,79 \mathrm{~b}$ & $4,57 \mathrm{~b}$ & $5,20 \mathrm{ab}$ & \\
\hline & \multicolumn{5}{|c|}{$\mathbf{P}$} & \\
\hline Com & 2,69 & 4,00 & 2,46 & 2,59 & 2,90 & $2,70 \mathrm{~A}$ \\
\hline Sem & 2,40 & 3,09 & 2,32 & 1,49 & 2,03 & $2,30 \mathrm{~B}$ \\
\hline \multirow[t]{2}{*}{ Médias } & $2,54 \mathrm{ab}$ & $3,50 \mathrm{a}$ & $2,39 \mathrm{a}$ & $2,09 \mathrm{a}$ & $2,46 a$ & \\
\hline & \multicolumn{5}{|c|}{$\mathrm{K}$} & \\
\hline Com & 21,15 & 24,30 & 14,05 & 15,90 & 17,44 & $18,57 \mathrm{~A}$ \\
\hline Sem & 15,06 & 20,42 & 15,69 & 8,82 & 12,56 & $14,51 \mathrm{~B}$ \\
\hline \multirow[t]{2}{*}{ Médias } & $18,10 \mathrm{ab}$ & $22,36 \mathrm{a}$ & $14,87 \mathrm{bc}$ & $12,36 \mathrm{c}$ & $15,00 \mathrm{bc}$ & \\
\hline & \multicolumn{5}{|c|}{$\mathrm{Ca}$} & \\
\hline Com & 2,80 & 3,36 & 2,14 & 2,61 & 2,62 & $2,08 \mathrm{~A}$ \\
\hline Sem & 2,77 & 3,37 & 2,47 & 1,76 & 2,19 & $2,50 \mathrm{~A}$ \\
\hline \multirow[t]{2}{*}{ Médias } & $2,76 \mathrm{~b}$ & $3,37 \mathrm{a}$ & $2,31 \mathrm{bc}$ & $2,19 \mathrm{c}$ & $2,40 \mathrm{bc}$ & \\
\hline & \multicolumn{5}{|c|}{$\mathrm{Mg}$} & \\
\hline Com & 1,48 & 1,82 & 1,21 & 1,29 & 1,42 & $1,44 \mathrm{~A}$ \\
\hline Sem & 1,39 & 1,71 & 1,30 & 0,80 & 1,11 & $1,26 \mathrm{~A}$ \\
\hline \multirow[t]{2}{*}{ Médias } & $1,44 \mathrm{~b}$ & $1,76 \mathrm{a}$ & $1,26 \mathrm{bc}$ & $1,05 \mathrm{c}$ & $1,27 \mathrm{bc}$ & \\
\hline & \multicolumn{5}{|c|}{$S$} & \\
\hline Com & 5,29 & 5,84 & 4,33 & 4,76 & 6,66 & $5,37 \mathrm{~A}$ \\
\hline Sem & 4,24 & 5,36 & 4,90 & 2,98 & 3,76 & $4,25 \mathrm{~B}$ \\
\hline Médias & $4,76 \mathrm{c}$ & $5,60 \mathrm{a}$ & $4,62 \mathrm{c}$ & $3,87 \mathrm{~d}$ & $5,21 \mathrm{~b}$ & \\
\hline
\end{tabular}

Nas linhas, as médias seguidas pela mesma letra minúscula e, nas colunas, da mesma letra maiúscula não diferem entre si $(P<0,05)$ pelo teste de Duncan. 
Tabela 9 - Teores médios de micronutrientes $\left(\mu \mathrm{g} \mathrm{g}^{-1}\right)$ na parte aérea de genótipos de milho cultivados em solução nutritiva, inoculados e não inoculados com uma mistura de estirpes homólogas de A.lipoferum e A.brasilense, 20 dias após a germinação. Médias de três repetições.

\begin{tabular}{|c|c|c|c|c|c|c|}
\hline \multirow[b]{2}{*}{ Inoculação } & \multicolumn{5}{|c|}{ Genótipos } & \multirow[b]{2}{*}{ Médias } \\
\hline & CMS 13 & CMS 36 & BR 451 & S.ELITE & CMS 51 & \\
\hline \multicolumn{7}{|c|}{$\mathrm{Cu}$} \\
\hline Com & 13,74 & 14,57 & 18,72 & 16,39 & 14,92 & $15,67 \mathrm{~A}$ \\
\hline Sem & 12,06 & 17,60 & 17,69 & 17,66 & 15,78 & $16,16 \mathrm{~A}$ \\
\hline Médias & $12,90 \mathrm{a}$ & $16,08 \mathrm{a}$ & $18,20 \mathrm{a}$ & $17,02 \mathrm{a}$ & $15,35 \mathrm{a}$ & \\
\hline \multicolumn{7}{|c|}{$\overline{M n}$} \\
\hline Com & 120,67 & 128,40 & 108,51 & 79,90 & 103,18 & $108,13 \mathrm{~B}$ \\
\hline Sem & 92,26 & 103,22 & 86,07 & 73,40 & 82,91 & $87,57 \mathrm{~A}$ \\
\hline Médias & $106,46 a b$ & $115,81 \mathrm{a}$ & $97,29 \mathrm{bc}$ & $76,65 d$ & $93,04 \mathrm{c}$ & \\
\hline \multicolumn{7}{|c|}{ Mo } \\
\hline Com & 1,51 & 1,71 & 1,73 & 2,11 & 2,80 & $1,97 \mathrm{~A}$ \\
\hline Sem & 0,72 & 2,17 & 1,49 & 2,49 & 2,20 & $1,82 \mathrm{~A}$ \\
\hline Médias & $1,12 \mathrm{c}$ & $1,94 \mathrm{ab}$ & $1,61 b c$ & $2,30 \mathrm{ab}$ & $2,50 \mathrm{a}$ & \\
\hline \multicolumn{7}{|c|}{$\overline{\mathrm{Zn}}$} \\
\hline Com & 34,66 & 37,89 & 39,78 & 46,18 & 38,32 & $39,37 \mathrm{~A}$ \\
\hline Sem & 25,30 & 36,36 & 35,84 & 43,55 & 23,07 & $32,82 \mathrm{~A}$ \\
\hline Médias & $29,98 \mathrm{a}$ & 37,13 a & $37,81 \mathrm{a}$ & 44,86 a & $30,70 \mathrm{a}$ & \\
\hline
\end{tabular}

Nas linhas, as médias seguidas pela mesma letra minúscula e, nas colunas, da mesma letra maiúscula não diferem entre si $(\mathrm{P}<0,05)$ pelo teste de Duncan. 
Tabela 10 - Conteúdos médios de micronutrientes ( $\mu \mathrm{g} /$ planta) na parte aérea de genótipos de milho cultivados em solução nutritiva, inoculados e não inoculados com uma mistura de estirpes homólogas de A.lipoferum e $A$. brasilense, 20 dias após a germinação. Médias de três repetições.

\begin{tabular}{|c|c|c|c|c|c|c|}
\hline \multirow[b]{2}{*}{ Inoculação } & \multicolumn{5}{|c|}{ Genótipo } & \multirow[b]{2}{*}{ Média } \\
\hline & CMS 13 & CMS 36 & BR 451 & S. ELITE & CMS 51 & \\
\hline \multicolumn{7}{|c|}{$\mathrm{Cu}$} \\
\hline Com & $3,90 \mathrm{a}$ & $4,66 a$ & $4,25 \mathrm{a}$ & $4,26 a$ & $3,97 \mathrm{a}$ & $4,21 \mathrm{~A}$ \\
\hline Sem & $3,64 \mathrm{a}$ & 5,71 a & $4,98 \mathrm{a}$ & $2,86 \mathrm{a}$ & $3,57 \mathrm{a}$ & $4,15 \mathrm{~A}$ \\
\hline Médias & 3,77 a & $5,18 \mathrm{a}$ & $4,61 \mathrm{a}$ & $3,56 \mathrm{a}$ & 3,77 a & \\
\hline \multicolumn{7}{|c|}{$\mathrm{Mn}$} \\
\hline Com & 34,80 & 42,55 & 24,15 & 20,85 & 27,25 & $29,92 \mathrm{~A}$ \\
\hline Sem & 28,21 & 33,50 & 24,26 & 11,95 & 19,11 & $23,41 \mathrm{~B}$ \\
\hline Médias & $31,50 \mathrm{~b}$ & 38,03 a & $24,21 \mathrm{c}$ & $16,40 \mathrm{~d}$ & $23,18 \mathrm{c}$ & 1 \\
\hline \multicolumn{7}{|c|}{ Mo } \\
\hline Com & 0,43 & 0,55 & 0,38 & 0,56 & 0,73 & $0,53 \mathrm{~A}$ \\
\hline Sem & 0,23 & 0,70 & 0,42 & 0,40 & 0,48 & $0,45 \mathrm{~A}$ \\
\hline Médias & $0,33 \mathrm{~b}$ & $0,2 \mathrm{a}$ & $0,40 a b$ & $0,48 \mathrm{ab}$ & $0,65 \mathrm{a}$ & \\
\hline \multicolumn{7}{|c|}{$\mathrm{Zn}$} \\
\hline Com & 9,80 & 12,26 & 8,85 & 12,03 & 9,97 & $10,58 \mathrm{~A}$ \\
\hline Sem & 7,70 & 11,71 & 9,93 & 7,07 & 5,01 & $8,28 \mathrm{~B}$ \\
\hline Médias & $8,75 \mathrm{c}$ & $11,98 \mathrm{a}$ & $9,39 \mathrm{~b}$ & $9,55 \mathrm{~b}$ & $7,49 \mathrm{~d}$ & \\
\hline
\end{tabular}

Nas linhas, as médias seguidas pela mesma letra minúscula e, nas colunas, da mesma letra maiúscula não diferem entre si $(\mathrm{P}<0,05)$ pelo teste de Duncan. 
de zinco, a inoculação reduziu os de manganês nas raizes (Tabelas 13 e 14) e, consequentemente, não se tratou de efeito de diluição.

As espécies de plantas e mesmo cultivares da mesma espécie difrerem na sua habilidade de se desenvolverem sob estresses nutricionais (Gabelman \& Gerloff, 1983; Nielsen \& Barber, 1978). Genótipos de milho variam na sua composição em macro e micronutrientes (Clark et al., 1974). Essas diferenças tem sido atribuidas aos parâmetros morfológicos e físiológicos (Kuchenbuch \& Jung, 1988).

Os resultados obtidos mostram a importância do genótipo da planta hospedeira nas interações entre milho e as bactérias do gênero Azospirillum, corroborando a hipótese de que a resposta da planta aos microrganismo é fortemente regulada por fatores do controle genético do hospedeiro. Isto sugere a possibilidade de se selecionarem genótipos de milho que apresentem maior compatibilidade com bactérias diazotróficas. É importante observar que houve maior resposta à inoculação nos genótipos que foram selecionados como materiais produtivos no campo,em condições de estresse em nitrogênio.

Diferentes pesquisas mostram aumentos no crescimento, $\mathrm{N}$ total $\mathrm{e}$ produção de milho após inoculação com bactérias do gênero Azospirillum (Lin et al., 1983; Sarig et al., 1988). Lin et al. (1983) relatam aumentos na absorção dos íons $\mathrm{NO}_{3}{ }^{-}$ $\mathrm{H}_{2} \mathrm{PO}_{4}^{-}$e $\mathrm{K}^{+}$em segmentos de raízes de milho inoculadas com Azospirillum. Dados similares foram observados para plantas de sorgo pelos mesmos autores. 
Tabela 11 - Teores médios de macronutrientes $\left(\mathrm{g} \mathrm{kg}^{-1}\right)$ em raízes de genótipos de milho cultivados em solução nutritiva, inoculados e não inoculados com uma mistura de estirpes homólogas A.lipoferum e A.brasilense, 20 dias após a germinação. Médias de três repetições.

\begin{tabular}{|c|c|c|c|c|c|c|}
\hline \multirow[b]{2}{*}{ Inoculação } & \multicolumn{5}{|c|}{ Genótipo } & \multirow[b]{2}{*}{ Médias } \\
\hline & CMS 13 & CMS 36 & BR 451 & S.ELITE & CMS 51 & \\
\hline & \multicolumn{5}{|c|}{$\mathbf{N}$} & \multirow[b]{2}{*}{$15,97 \mathrm{~A}$} \\
\hline Com & 14,90 & 16,83 & 16,43 & 16,63 & 15,07 & \\
\hline Sem & 12,00 & 13,43 & 13,07 & 13,97 & 12,80 & $13,05 \mathrm{~B}$ \\
\hline \multirow[t]{2}{*}{ Médias } & 13,45 a & $15,13 \mathrm{a}$ & $14,75 \mathrm{a}$ & $15,30 \mathrm{a}$ & $13,93 \mathrm{a}$ & \multirow[b]{3}{*}{$38,40 \mathrm{~A}$} \\
\hline & \multicolumn{5}{|c|}{$\bar{K}$} & \\
\hline Com & 39,90 & 38,67 & 38,80 & 41,63 & 33,00 & \\
\hline Sem & 36,17 & 34,43 & 41,00 & 34,50 & 33,00 & $35,82 \mathrm{~A}$ \\
\hline \multirow[t]{2}{*}{ Médias } & $38,03 \mathrm{a}$ & $36,55 \mathrm{a}$ & $39,90 \mathrm{a}$ & $38,07 \mathrm{a}$ & $33,00 \mathrm{a}$ & \\
\hline & \multicolumn{5}{|c|}{$\mathrm{P}$} & \\
\hline Com & 2,79 & 4,03 & 2,41 & 2,82 & 2,92 & $3,00 \mathrm{~A}$ \\
\hline Sem & 2,45 & 3,10 & 2,37 & 1,46 & 2,03 & $2,28 \mathrm{~B}$ \\
\hline \multirow[t]{2}{*}{ Médias } & $2,62 \mathrm{ab}$ & $3,56 \mathrm{a}$ & $2,41 \mathrm{~b}$ & $2,13 b$ & $2,47 \mathrm{~b}$ & \\
\hline & \multicolumn{5}{|c|}{$\mathrm{Ca}$} & \\
\hline Com & 5,63 & 5,23 & 5,70 & 5,60 & 5,07 & $5,45 \mathrm{~B}$ \\
\hline Sem & 7,53 & 6,47 & 7,17 & 6,97 & 6,80 & $6,99 \mathrm{~A}$ \\
\hline \multirow[t]{2}{*}{ Médias } & $6,58 \mathrm{a}$ & $5,85 \mathrm{a}$ & $6,43 \mathrm{a}$ & $6,28 \mathrm{a}$ & 5,93 a & \\
\hline & \multicolumn{5}{|c|}{$\mathrm{Mg}$} & \\
\hline Com & 5,47 & 5,23 & 5,50 & 5,73 & 5,00 & $5,39 \mathrm{~B}$ \\
\hline Sem & 6,63 & 5,83 & 7,00 & 6,30 & 6,40 & $6,43 \mathrm{~A}$ \\
\hline \multirow[t]{2}{*}{ Médias } & $6,05 \mathrm{a}$ & $5,53 \mathrm{a}$ & $6,25 \mathrm{a}$ & $6,02 \mathrm{a}$ & $5,70 \mathrm{a}$ & \\
\hline & \multicolumn{5}{|c|}{$\overline{\mathrm{S}}$} & \\
\hline Com & 4,63 & 4,80 & 4,70 & 5,33 & 4,43 & $4,78 \mathrm{~A}$ \\
\hline Sem & 5,13 & 4,83 & 5,37 & 4,80 & 5,23 & $5,07 \mathrm{~A}$ \\
\hline Médias & $4,88 \mathrm{a}$ & $4,82 \mathrm{a}$ & $5,03 \mathrm{a}$ & $5,07 \mathrm{a}$ & $4,83 \mathrm{a}$ & \\
\hline
\end{tabular}

Nas linhas, as médias seguidas pela mesma letra minúscula e, nas colunas, da mesma letra maiúscula não diferem entre si $(\mathrm{P}<0,05)$ pelo teste de Duncan. 
Tabela 12 - Conteúdos médios de macronutrientes (mg/planta) em raízes de genótipos de milho cultivados em solução nutritiva, inoculados e não inoculados com uma mistura de estirpes homólogas A.lipoferum e A.brasilense, 20 dias após a germinação. Médias de três repetições.

\begin{tabular}{|c|c|c|c|c|c|c|}
\hline \multirow[b]{2}{*}{ Inoculação } & \multicolumn{5}{|c|}{ Genótipos } & \multirow[b]{2}{*}{ Médias } \\
\hline & CMS 13 & CMS 36 & BR.451 & S.ELITE & CMS 51 & \\
\hline & \multicolumn{5}{|c|}{$\mathrm{N}$} & \\
\hline Com & 3,91 & 4,11 & 3,91 & 2,56 & 3,12 & $3,52 \mathrm{~A}$ \\
\hline Sem & 3,32 & 4,01 & 2,36 & 2,75 & 2,95 & $3,08 \mathrm{~A}$ \\
\hline \multirow[t]{2}{*}{ Médias } & $3,61 \mathrm{a}$ & $4,06 \mathrm{a}$ & $3,14 \mathrm{a}$ & $2,65 \mathrm{a}$ & $3,03 \mathrm{a}$ & \multirow[b]{3}{*}{$1,87 \mathrm{~A}$} \\
\hline & \multicolumn{5}{|c|}{$\mathrm{P}$} & \\
\hline Com & 2,43 & 2,18 & 1,87 & 1,19 & 1,70 & \\
\hline Sem & 2,32 & 2,96 & 1,30 & 1,30 & 1,72 & $1,92 \mathrm{~A}$ \\
\hline \multirow[t]{2}{*}{ Médias } & $2,38 \mathrm{a}$ & $2,57 \mathrm{a}$ & $1,58 \mathrm{a}$ & $1,24 \mathrm{a}$ & $1,71 \mathrm{a}$ & \multirow{4}{*}{$\begin{array}{l}8,19 \mathrm{~A} \\
846\end{array}$} \\
\hline & \multicolumn{5}{|c|}{$\overline{\mathrm{K}}$} & \\
\hline Com & 9,99 & 9,22 & 9,03 & 6,13 & 6,59 & \\
\hline Sem & 10,04 & 10,42 & 7,44 & 6,82 & 7,59 & \\
\hline \multirow{2}{*}{ Médias } & $10,02 \mathrm{a}$ & $9,82 \mathrm{a}$ & $8,24 \mathrm{ab}$ & $6,48 b$ & \multirow[t]{2}{*}{$7,09 \mathrm{~b}$} & - \\
\hline & \multicolumn{4}{|c|}{$\mathrm{Ca}$} & & \multirow{3}{*}{$\begin{array}{l}1,18 \mathrm{~B} \\
1,67 \mathrm{~A}\end{array}$} \\
\hline Com & 1,44 & 1,25 & 1,33 & 0,87 & 1,02 & \\
\hline Sem & 2,09 & 1,92 & 1,32 & 1,37 & 1,56 & \\
\hline \multirow[t]{2}{*}{ Médias } & $1,76 \mathrm{a}$ & $1,59 \mathrm{ab}$ & $1,32 \mathrm{bc}$ & $1,12 \mathrm{c}$ & $1,29 \mathrm{bc}$ & \multirow{4}{*}{$\begin{array}{l}1,16 \mathrm{~B} \\
1,52 \mathrm{~A}\end{array}$} \\
\hline & \multicolumn{5}{|c|}{$\mathrm{Mg}$} & \\
\hline Com & 1,40 & 1,24 & 1,27 & 0,89 & 0,99 & \\
\hline Sem & 1,84 & 1,78 & 1,29 & 1,24 & 1,47 & \\
\hline \multirow[t]{2}{*}{ Médias } & $1,62 \mathrm{a}$ & $1,51 \mathrm{a}$ & $1,28 \mathrm{a}$ & $1,06 \mathrm{a}$ & $1,23 \mathrm{a}$ & \\
\hline & \multicolumn{5}{|c|}{$S$} & \multirow[b]{2}{*}{$1,03 \mathrm{~A}$} \\
\hline Com & 1,18 & 1,52 & 1,09 & 0,82 & 0,89 & \\
\hline Sem & 1,42 & 1,46 & 0,99 & 0,94 & 1,20 & $1,20 \mathrm{~A}$ \\
\hline Médias & $1,30 \mathrm{a}$ & $1,31 \mathrm{a}$ & $1,04 \mathrm{a}$ & $0,87 \mathrm{a}$ & $1,05 \mathrm{a}$ & \\
\hline
\end{tabular}

Nas linhas, as médias seguidas pela mesma letra minúscula e, nas colunas, da mesma letra maiúscula não diferem entre si $(P<0,05)$ pelo teste de Duncan. 
Tabela 13 - Teores médios de micronutrientes $\left(\mathrm{g} \mathrm{kg}^{-1}\right)$ em-raízes de genótipos de milho cultivados em solução nutritiva, inoculados e não inoculados com uma mistura de estirpes homólogas A.lipoferum e A.brasilense, 20 dias após a germinação. Médias de três repetições.

\begin{tabular}{|c|c|c|c|c|c|c|}
\hline \multirow[b]{2}{*}{ Inoculação } & \multicolumn{5}{|c|}{ Genótipos } & \multirow{3}{*}{ Médias } \\
\hline & CMS 13 & CMS 36 & BR 451 & S.ELITE & CMS 51 & \\
\hline \multicolumn{6}{|c|}{$\mathrm{Cu}$} & \\
\hline Com & 32,76 & 39,84 & 37,19 & 39,32 & 40,20 & $37,86 \mathrm{~A}$ \\
\hline Sem & 31,55 & 33,72 & 36,94 & 33,72 & 37,57 & $34,70 \mathrm{~A}$ \\
\hline Médias & $32,15 \mathrm{a}$ & $36,78 \mathrm{a}$ & $37,06 \mathrm{a}$ & $36,52 \mathrm{a}$ & 38,89 a & \\
\hline \multicolumn{7}{|c|}{$\mathrm{Mn}$} \\
\hline Com & 164,47 & 209,63 & 237,69 & 196,24 & 185,98 & $198,80 \mathrm{~B}$ \\
\hline Sem & 308,62 & 312,02 & 335,41 & 172,32 & 297,70 & $285,21 \mathrm{~A}$ \\
\hline Médias & $236,54 \mathrm{a}$ & $260,82 \mathrm{a}$ & $286,55 \mathrm{a}$ & $184,28 \mathrm{a}$ & $241,84 \mathrm{a}$ & \\
\hline \multicolumn{7}{|c|}{ Mo } \\
\hline Com & 45,27 & 49,63 & 50,37 & 40,60 & 52,67 & $47,71 \mathrm{~A}$ \\
\hline Sem & 20,75 & 29,00 & 21,20 & 16,50 & 21,21 & $21,73 \mathrm{~B}$ \\
\hline Médias & $33,01 \mathrm{a}$ & 39,31 a & 35,79 a & 28,55 a & 36,94 a & \\
\hline \multicolumn{7}{|c|}{$\mathrm{Zn}$} \\
\hline Com & 101,04 & 102,22 & 122,85 & 112,58 & 109,01 & $109,54 \mathrm{~A}$ \\
\hline Sem & 97,25 & 88,59 & 96,38 & 89,42 & 94,04 & $93,13 \mathrm{~B}$ \\
\hline Médias & $99,15 \mathrm{a}$ & $95,40 \mathrm{a}$ & $109,61 \mathrm{a}$ & $101,00 \mathrm{a}$ & $101,52 \mathrm{a}$ & \\
\hline
\end{tabular}

Nas linhas, as médias seguidas pela mesma letra maiúscula e, nas colunas, da mesma letra maiúscula não diferem entre si $(\mathrm{P}<0,05)$ pelo teste de Duncan. 
Tabela 14 - Conteúdos médios de micronutrientes ( $\mu \mathrm{g} /$ planta) em raízes de genótipos de milho cultivados em solução nutritiva, inoculados e não inoculados com uma mistura de estirpes homólogas de A.lipoferum e A.brasilense, 20 dias após a germinação. Médias de três repetições.

\begin{tabular}{|c|c|c|c|c|c|c|}
\hline \multirow[b]{2}{*}{ Inoculação } & \multicolumn{5}{|c|}{ Genótipos } & \multirow[b]{2}{*}{ Médias } \\
\hline & CMS 13 & CMS 36 & BR 451 & S.ELITE & CMS 51 & \\
\hline \multicolumn{7}{|c|}{$\overline{\mathrm{Cu}}$} \\
\hline Com & 8,50 & 9,80 & 8,73 & 5,99 & 8,07 & $8,22 \mathrm{~A}$ \\
\hline Sem & 8,71 & 10,10 & 6,66 & 6,59 & 8,64 & $8,14 \mathrm{~A}$ \\
\hline Médias & $8,61 \mathrm{a}$ & $9,95 \mathrm{a}$ & $7,69 \mathrm{a}$ & $6,29 \mathrm{a}$ & $8,36 \mathrm{a}$ & \\
\hline \multicolumn{7}{|c|}{ Mn } \\
\hline Com & 43,22 & 51,32 & 54,00 & 28,89 & 34,07 & $42,30 \mathrm{~B}$ \\
\hline Sem & 85,62 & 93,66 & 64,41 & 33,62 & 68,52 & $69,16 \mathrm{~A}$ \\
\hline Médias & $64,42 \mathrm{a}$ & $72,49 a$ & $59,21 \mathrm{a}$ & $31,26 \mathrm{a}$ & $51,30 \mathrm{a}$ & \\
\hline \multicolumn{7}{|c|}{ Mo } \\
\hline Com & 11,86 & 11,74 & 11,99 & 6,51 & 10,89 & $10,60 \mathrm{~A}$ \\
\hline Sem & 5,73 & 8,54 & 3,89 & 3,25 & 4,88 & $5,26 \mathrm{~B}$ \\
\hline Médias & $8,79 \mathrm{a}$ & $10,14 \mathrm{a}$ & $7,94 \mathrm{ab}$ & $4,88 \mathrm{~b}$ & $7,88 \mathrm{ab}$ & \\
\hline \multicolumn{7}{|c|}{$\mathrm{Zn}$} \\
\hline Com & 26,01 & 24,88 & 28,81 & 17,65 & 21,70 & $23,82 \mathrm{~A}$ \\
\hline Sem & 26,92 & 27,10 & 17,93 & 17,66 & 21,63 & $22,25 \mathrm{~B}$ \\
\hline Médias & 26,45 a & $25,99 \mathrm{a}$ & $23,37 \mathrm{a}$ & $17,65 \mathrm{a}$ & $21,67 \mathrm{a}$ & \\
\hline
\end{tabular}

Nas linhas, as médias seguidas pela mesma letra minúscula e, nas colunas, da mesma letra maiúscula não diferem entre si $(\mathrm{P}<0,05)$ pelo teste de Duncan. 
Tabela 15 - Somas parciais e total de intersecções de raizes de genótipos de milho cultivados em solução nutritiva, inoculados e não inoculados com uma mistura de estirpes homólogas de $A$. lipoferum e $A$. brasilense, 20 dias após a germinação. Média de três repetições.

\begin{tabular}{|c|c|c|c|c|c|c|}
\hline \multirow[b]{2}{*}{ Inoculação } & \multicolumn{5}{|c|}{ Genótipo } & \multirow{3}{*}{ Médias } \\
\hline & CMS 13 & CMS 36 & BR 451 & S. ELITE & CMS 51 & \\
\hline & \multicolumn{5}{|c|}{ Inters 1 } & \\
\hline Com & 41,017 & 30,713 & 30,503 & 44,497 & 31,830 & $35,712 \mathrm{~A}$ \\
\hline Sem & 40,165 & 37,783 & 30,040 & 41,487 & 39,603 & $37,816 \mathrm{~A}$ \\
\hline \multirow[t]{2}{*}{ Médias } & $40,591 \mathrm{a}$ & $34,248 \mathrm{a}$ & $30,272 \mathrm{a}$ & $42,992 \mathrm{a}$ & 35,717 a & \\
\hline & \multicolumn{5}{|c|}{ Inters2 } & \\
\hline Com & 22,913 & 17,653 & 15,773 & 19,930 & 15,832 & $18,412 \mathrm{~A}$ \\
\hline Sem & 17,823 & 14,030 & 14,593 & 12,170 & 18,800 & $15,483 \mathrm{~A}$ \\
\hline \multirow[t]{2}{*}{ Média } & $20,368 \mathrm{a}$ & $15,842 \mathrm{a}$ & $15,163 \mathrm{a}$ & $16,050 \mathrm{a}$ & $17,316 \mathrm{a}$ & \\
\hline & \multicolumn{5}{|c|}{ Inters3 } & \\
\hline Com & 5,857 & 4,247 & 2,798 & 4,536 & 2,354 & $3,958 \mathrm{~A}$ \\
\hline Sem & 4,693 & 2,795 & 2,308 & 1,858 & 3,107 & $2,952 \mathrm{~A}$ \\
\hline \multirow[t]{2}{*}{ Média } & $5,275 \mathrm{a}$ & $3,521 \mathrm{a}$ & $2,553 \mathrm{a}$ & $3,197 \mathrm{a}$ & $2,730 \mathrm{a}$ & \\
\hline & \multicolumn{5}{|c|}{ Inters Total } & \\
\hline Com & 70,130 & 52,625 & 51,163 & 68,970 & 50,013 & $58,580 \mathrm{~A}$ \\
\hline Sem & 62,687 & 54,613 & 46,880 & 55,518 & 61,517 & $56,243 \mathrm{~A}$ \\
\hline Média & $66,408 \mathrm{a}$ & 53,619 a & $49,022 \mathrm{a}$ & $62,244 \mathrm{a}$ & 55,765 a & \\
\hline
\end{tabular}

Nas linhas, as médias seguidas pela mesma letra minúscula e, nas colunas, da mesma letra maiúscula não diferem entre si $(\mathrm{P}<0,05)$ pelo teste de Duncan. 
Alguns trabalhos sugerem que o processo de fixação biológica não é única causa para o aumento no crescimento das plantas em simbiose associativa. Essas bactérias elicitam substâncias promotoras de crescimento, como AIA (Tien et al., 1979) e aumentam a absorção de minerais pelas raízes (Kapulnik et al., 1985). Kapulnik et al., (1985) encontraram influência positva da inoculação em trigo, cultivado em solução nutritiva, com concomitante aumento do sistema radicular e atribuiram tais diferenças aos efeitos hormonais. Em contraste, os dados desta pesquisa mostram que o maior acúmulo de nutrientes não foi acompanhado de alterações nas variáveis morfológicas avaliadas no sistema radicular (Tabela 15, Figura 9).

Em relação ao zinco, a inoculação provocou aumento significativo no seu teor e conteúdo nas raízes e conteúdo na parte aérea. E é conhecido o papel deste elemento na biossíntese de AIA (Tsui, 1948) e, portanto, importante para a ação hormonal. Assim, os aumentos observados no acúmulo de nutrientes não podem ser atribuidos unicamente aos efeitos hormonais. Ademais, não se observou redução na concentração de $\mathrm{N}$ na parte aérea das plantas, efeito esse esperado em função de hormônios. Conclui-se, portanto, que houve contribuição da fixação biológica de $\mathrm{N}_{2}$ para o crescimento e incorporação de nitrogênio nas plantas inoculadas. Ganhos no crescimento e incorporação de nutrientes em plantas de arroz cultivadas em solução nutritiva e inoculadas com Azospirillum, sem aumento da massa radicular, foram também relatados por Murty \& Ladha (1988). 

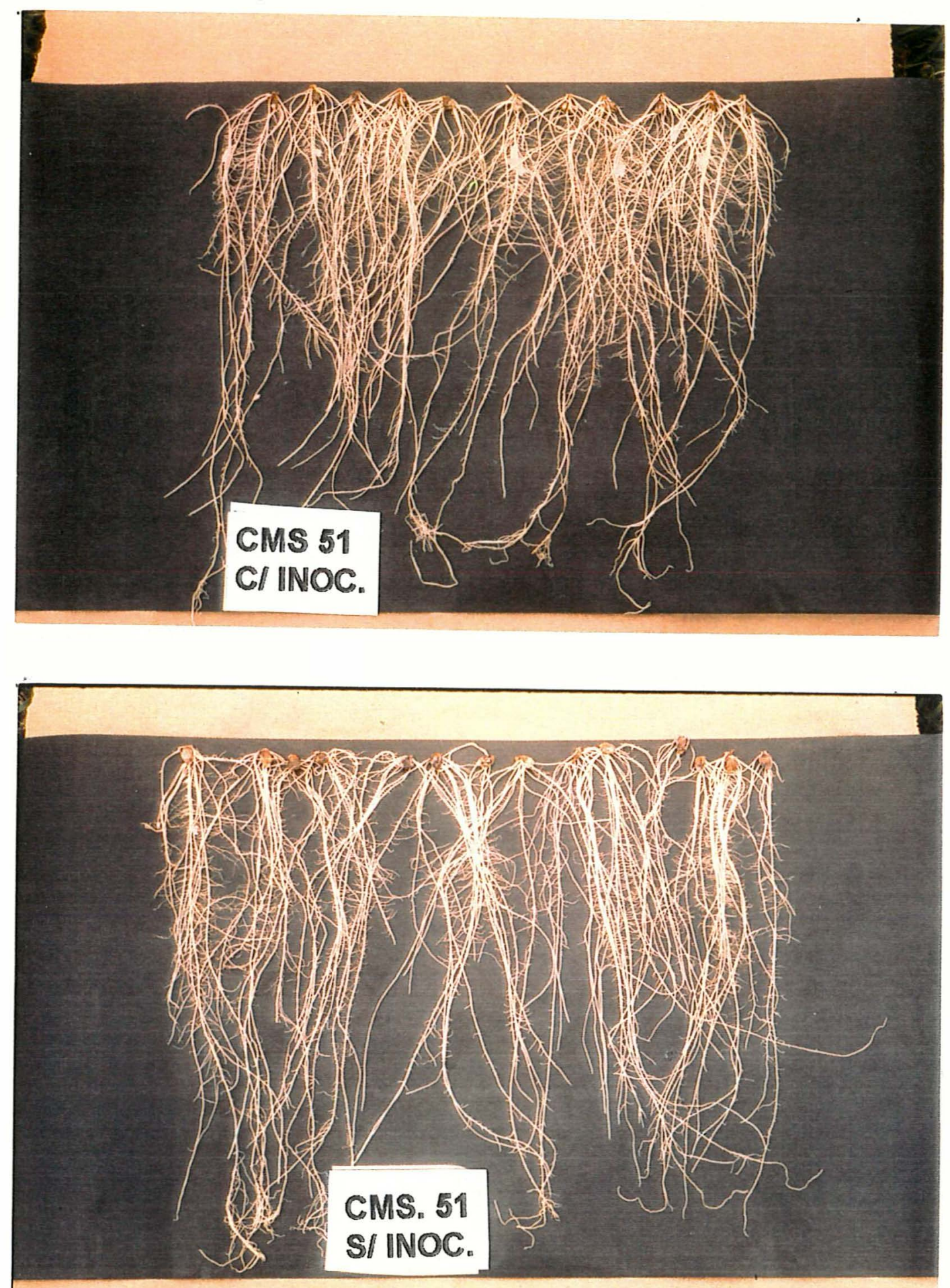

Figura 9 - Comparação do sistema radicular do genótipo de milho CMS 51 cultivado em solução nutritiva, inoculado e não inoculado com uma mistura de estirpes homólogas de $A$. lipoferum e $A$. brasilense, 20 dias após a germinação. 
Esses resultados encontrados, aparentemente conflitantes, podem ser parcialmente explicados em função da idade da planta e das concentrações de inóculos utilizadas. Bashan \& Levanony (1990) e Kapulnik et al. (1985) relataram que suspensões com concentrações elevadas de bactérias inibiram as alterações morfológicas do sistema radicular e que baixas concentrações não apresentaram nenhum efeito. Fallik et al. (1989) reportaram a densidade em torno de $10^{7}$ células viáveis por $\mathrm{ml}$ como concentração ótima de bactérias para inoculação em plantas de milho, portanto similar a deste trabalho, $4,0 \times 10^{7}$ células viáveis por ml. Nos dados apresentados, não se observou alteração na soma total de intersecções e no comprimento da raiz seminal (dados não mostrados). Nota-se que a metodologia foi sensível suficiente para detectar diferenças entre genótipos.

\subsubsection{Efeito da inoculação com Azospirillum spp. sobre a atividade da redutase do nitrato}

Na Tabela 16, estão apresentados os dados médios da atividade da redutase do nitrato nos tratamentos avaliados. Em geral, a atividade da enzima foi baixa no sistema radicular, independente da inoculação e dos genótipos, sendo os efeitos desses tratamentos não significativos. A interação inoculação $\mathrm{x}$ genótipos foi 
significativa, onde alguns genótipos foram influenciados positivamente pela inoculação e outros negativamente.

Como a redutase do nitrato é uma enzima do tipo indutível pelo substrato (Beevers \& Hageman, 1969), os baixos níveis de atividade podem ser parcialmente explicado pela disponibilidade limitada de $\mathrm{N}$ utilizada no meio de crescimento das plantas. Por outro lado, na parte aérea das plantas, a atividade da enzima aumentou significativamente na presença da inoculação, sendo a magnitude do acréscimo em função dos genótipos (Tabela 16), indicando que, em milho, inoculado ou não, o nitrogênio absorvido na forma de nitrato é reduzido, principalmente, nas folhas.

O incremento de 3 vezes observado para a atividade da redutase do nitrato na parte aérea pode estar associado ao maior conteúdo de Mo nas raízes e ao de $S$ nas folhas (Tabela 8). Esses dois nutrientes desempenham papel importante na síntese e atividade da enzima, uma vez que ela é rica em grupos sulfídricos (Marschner, 1986) e ativada pelo Mo como cofator (Beevers \& Hageman, 1969). Essa hipótese é suportada por Vieira (1994) que encontrou maior atividade da enzima com aplicação foliar de Mo. Resultados similares têm sido obtidos através da inoculação com Azospirillum sobre outras enzimas (Bashan \& Levanony, 1990), demonstrando o papel direto ou indireto desta bactéria no metabolismo de $\mathrm{N}$ da planta hospedeira. A maior atividade da redutase do nitrato em folhas de trigo tem sido atribuída à redutase do nitrato da bactéria e vista como uma das explicações para o aumento de $\mathrm{N}$ em plantas inoculadas (Ferreira et al., 1987). Deste modo, além da fixação de $N_{2}$, o aumento na assimilação de nitrato contribuiu com $\mathrm{N}$ para a planta. 
Tabela 16 - Atividade da redutase do nitrato em folhas e raízes de genótipos de milho cultivados em solução nutritiva, inoculados e não inoculados com uma mistura de estirpes homólogas de Azospirillum, 20 dias após a emergência. Médias de três repetições.

\begin{tabular}{|c|c|c|c|c|c|c|}
\hline \multirow[b]{2}{*}{ inoculaçāo } & \multicolumn{6}{|c|}{ Genótipos } \\
\hline & CMS 13 & CMS 36 & BR 451 & S. ELITE & CMS 51 & Médias \\
\hline & \multicolumn{6}{|c|}{ Raízes } \\
\hline \multicolumn{7}{|c|}{ 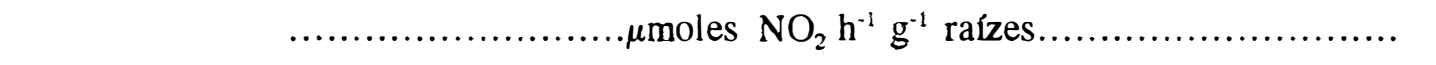 } \\
\hline COM & $0,092 \mathrm{~b}$ & $0,132 \mathrm{~b}$ & $0,230 \mathrm{~b}$ & $0,555 \mathrm{a}$ & $0,014 \mathrm{~b}$ & 0,169 \\
\hline SEM & 0,156 a & $0,098 \mathrm{a}$ & $0,304 \mathrm{a}$ & $0,063 \mathrm{a}$ & 0,224 a & 0,205 \\
\hline Médias & 0,124 & 0,116 & 0,267 & 0,309 & 0,119 & \\
\hline
\end{tabular}

Parte Aérea

. moles $\mathrm{NO}_{2} \mathrm{~h}^{-1} \mathrm{~g}^{-1}$ folhas

\begin{tabular}{ccccccc}
\hline COM & 1,277 & 1,167 & 1,884 & 2,219 & 1,161 & $1,541 \mathrm{~A}$ \\
SEM & 0,199 & 0,477 & 0,597 & 1,012 & 0,328 & $0,523 \mathrm{~B}$ \\
\hline Médias & $0,738 \mathrm{c}$ & $0,822 \mathrm{c}$ & $1,240 \mathrm{a}$ & $1,616 \mathrm{a}$ & $0,744 \mathrm{c}$ & \\
\hline \hline
\end{tabular}

Na coluna, médias seguidas pela mesma letra maiúscula, e minúscula na linha, não diferente significativamente ao nível de $5 \%$, pelo teste de Duncan. 
Adicionalmente, os dados mostram que um dos genótipos utilizados, a população sintético elite, que apresentou um nível de atividade superior a 2 vezes ao das demais, na ausência de inoculação, e maior resposta à presença da bactéria inoculada, possui alta capacidade produtiva sob estresse de $\mathrm{N}$ no campo, indicando ser esta medida enzimática uma ferramenta útil em seleção de variedades de milho visando maior eficiência no uso de nitrogênio e/ou fixação biológica de $\mathrm{N}_{2}$. 


\section{CONCLUSÕES}

De acordo com a metodologia utilizada, os resultados permitiram apresentar as seguintes conclusões:

a) Diferentes bactérias diazotróficas com características distintas de Azospirillum spp. podem ser isoladas de gramíneas.

b) Há predominância de diazotróficos antigenicamente similares à espécie de Azospirillum lipoferum em seiva de milho, indicando elevado grau de especifidade nestas interções associativas.

c) A atividade da redutase do nitrato aumentou nas folhas de milho em função da inoculação com Azospirillum spp., independente dos genótipos.

d) Observou-se elevada diversidade morfológica, serológica e bioquímica entre diazotróficos isolados.

f) As populações de milho apresentaram respostas diferenciais à inoculação com Azospirillum spp. em relação ao acúmulo de nutrientes. A população CMS 36 pode ser explorada como fonte de genótipos superiores visando eficiência para fixação biológica de $\mathrm{N}_{2}$. 


\section{REFERÊNCIAS BIBLIOGRÁFICAS}

AHMAD, M. H.; EAGLESHAM, A.R.J.; HASSOUNA, S. Examining serological of "Cowpea" rhizobia by te ELISA technique. Archeology Microbiology, v.130, p.281-287, 1981 .

ALBRECHT, S.L.; OKON, Y.; BURRIS, R. H. Effects of light and temperature on association between Zea mays and Spirillum lipoferum. Plant Physiology, v.60, p.528-531, 1977.

AL-MALLAH, M.K.; DAVEY, M.R.; COCKING, E.C. Formation of nodular structures on rice seedling by rhizobia. Journal Experimental Botany, v.40, p.473-478, 1989.

BALANDREAU, J.P.; MILLIER, C.R.; DOMMERGUES, Y.R. Diurnal variations of nitrogenase activity in the field. Applied Microbiology, v.27, p.662-665, 1974.

BALANDREAU, J.P.; MILLIER, C.R.; WEINHARD, P.; DUCERF, P.; DOMMERGUES, Y.R. Etude des variations e la fixation d azote dans une ulture de mais. Academic Science, v.282, p.1071-1074. 1976

BALDANI, V.L.D.; DÖBEREINER, J. Host-plant specificity in infection of cereal with Azospirillum spp., Soil Biology Biochemistry, v.12, p.433-440, 1980. 
BALDANI, J.I.; BALDANI, V.L.D.; DÖBEREINER, J. Inoculation of field-grown wheat (Triticum aestivum) with Azospirillum spp. in Brazil. Biology Fertilizer Soils, v.4, p.37-40, 1987.

BALDANI, J.I.; BALDANI, V.L.D.; SELDIN, L.; DÖBEREINER, J. Caracterization of Herbaspirillum seropedicae nov., sp. nov., a root-associated nitrogen - fixing bacterium. International Journal of Systematics Bacteriology, v.36, n.1, p.86-93, 1986.

BARAK, R.; NUR, I.; OKON, Y. Detection of chemotaxis in Azospirillum brasilense. Journal Applied Bacteriology, v.53, p.399-403, 1983.

BASHAN, Y; LEVANONY, H. Current status of Azospirillum inoculation technology: Azospirillum as a challenge for agriculture. Canadian Journal of Microbiology, v.36, p.591-605, 1990.

BEEVERS, L.; HAGEMAN, R.H. Nitrate reduction in higher plants. Annual Reviews Plant Physiology, v.20, p.495-522. 1969.

BLISS, F.A. Breeding common bean for improved biological nitrogen fixation. Plant and Soil, v.152, p.71-79, 1993.

BODDEY, R.M.; DÖBEREINER, J. Nitrogen fixation associated with grasses and cereals: recent results and perspectives for future research. Plant and Soil, v 108, p.53-65, 1988. 
BODDEY, R.M.; BALDANI, V.L.D.; BALDANI, J.I.; DÖBEREINER, J . Effects of inoculation of Azospirillum spp. on the nitrogen assimilation of field grown wheat. Plant and Soil, v.95, p. 109-121, 1986.

BODDEY, R.M.; OLIVEIRA, O.C.; URQUIAGA, S.; REIS, V.M.; OLIVARES, F.L. de; BALDANI, V. L. D.; DÖBEREINER, J. Biological nitrogen fixation associated with sugar cane and rice: Contribuition and prospects for improvement. Plant and Soil, v.174, p.195-209, 1995.

BOONEKAMP, M. Monoclonal antibodies and immunological techniques to detect plant pathogens. In: COST-88 WORKSHOP, 1., Wageningen, 1987. Proceedings. Wageningen: PUDOC, 1988. p 24-27.

BOTTINI, R.; FULCHIERI, M.; PEARCE, D.; PHARIS, R. P. Identification of gibberellins $\mathrm{A}_{1}, \mathrm{~A}_{3}$ and iso- $\mathrm{A}_{3}$ in cultures of Azospirillum lipoferum. Plant Physiology, v.90, p.45-47, 1989.

BROCK, T.D.; MADIGAN, M.T. Immunology and Immunity. In: BROCK,T.; MADIGAN, M.T. Biology of microrganisms. Prentice: Hall International, 1988. p.428-473.

BÜLOW, J.F.W. von. Plant influence in symbiotic nitrogen. In: DÖBEREINER, J. et al. (Ed.) Limitations and potentials for biological nitrogen fixation in the tropics. New York: Plenun Press, 1978. p.75-94. (Basic Life Science, 10). 
BÜLOW, J.F.W. von; DÖBEREINER, J. Potential for nitrogen fixation in maize genotypes in Brazil. Proceedings of the National Academic of Science of the United States of America, v.72, p.2389-2393, 1975.

BUTZ, R.G.; LONG, R.C. L-malate as an essent component of the xylem fluid of corn seedling. Plant Physiology, v.64, p.684-689. 1979.

CAMARGO, E.P.; LOPES, J.D. Anticorpos monoclonais. Ciência e Cultura, v.35, n.8, p.1062-1074, 1983.

CLARK, .M. F. Immunosorbent assay in plant pathology. Annual Review of Phytopathology, v.19, p.83-106, 1981.

CLARK, R.B.; BROWN, J. Differencial mineral uptake by maize inbreds. Communication Soil Science Plant Analysis, v.5, p.213-227. 1974.

COHEN, E.; OKON, Y.; KIGEL, J.; NUR, I.; HENIS, Y. Increase in dry weight and total nitrogen in Zea mays and Setaria italica associated with nitrogen - fixing Azospirillum spp. Plant Physiology, v.66, p.746-749, 1980.

CROZIER, A.; ARRUDA, P.; JASMIN, J.M.; MONTEIRO, A.M.; SANDBERG, G. Analysis of indol-3-acetic and related indoles in culture medium from Azospirillum lipoferum and Azospirillum brasiliense. Applied Environmental Microbiology, v.54, p.2883-2887, 1998. 
DAZZO, F.B.; MILAM, J.R. Serological studies of Spirillum lipoferum. Soil Crop Science Society Fla. Proceeding, v.35, p.122, 1976.

De BRUIJN, F.D.; JING, Y.; DAZZO, F.B. Potential and pitfalls of trying to extend symbiotic interation of nitrogen-fixing organisms to presently non-nodulated plants, such as rice. Plant and Soil, v. 174, p.225-240, 1995.

De-POLLI, H.; BOHLOOL, B.B.; DÖBEREINER, J. Serological differentiation of Azospirillum species belonging to different host-plant specificity groups. Archives of Microbiology, v.126, p.217-222, 1980.

De-POLLI, H.; MATSUI, E.; DÖBEREINER, J.; SALATI, E. Confirmation of nitrogen fixation in two tropical grasses by ${ }^{15} \mathrm{~N}_{2}$ incorporation. Soil Biology and Biochemistry, v.9, p.119-123, 1977.

DÖBEREINER, J. Forage grasses and grain crops. In: BERGERSEN, F.J. (Ed.) Methods for evaluation biological nitrogen fixation. Chichester,: John Wiley, 1980. p.535-555.

DÖBEREINER, J. Isolation and identification of root associated diazotrophs. In: INTERNATIONAL SYMPOSIUM ON NITROGEN FIXATION WITH NONLEGUMES, 4., Rio de Janeiro, 1987. Proceedings. Dordrechet: Kluwer Academic Publ., 1989. p.103-108. (Developments in Plant and Soil Sciences, 35).

DÖBEREINER, J. The genera Azospirillum and Herbaspirillum. In: BALLOWS, N. (Ed). The procariotes: a handbook on the biology of bacteria. Heidelberg: Springer Verlag, 1992. v.3, p.2236-2253. 
DÖBEREINER, J. Ten years of Azospirillum. In: KLINGMULLER, W. (Ed.). Azospirillum II: Genects, Physiology, Ecology. Birkhauser: Basel, 1983. p.9-23. (Experientia supplementum, 43).

DÖBEREINER, J.; BALDANI, V.L.D.; B ALDANI, J.I. Como isolar e identificar bactérias diazotróficas de plantas não-leguminosas. Brasília: EMBRAPA, SPI: Itaguaí: EMBRAPA,CNPAB, 1995. 60p.

DÖBEREINER, J.; DAY, J.M. Associative symbiosis in tropical grasses: Characterization of microorganisms and dinitrogen-fixing sites. In: NEWTON, W.E.; NYMAN, C.J.N. (Ed.). Nitogen fixation. Pullman: Washington State University Press, 1976. p.518-538.

DÖBEREINER, J.; De POLLI, H. Diazotrophic rhizocoenoses. In: STEWARD, W.D.P. (Ed).Nitrogen Fixation. New York, Academic Press: 1980. p.301-333.

DÖBEREINER, J.; DUQUE, F.F. Contribuição da pesquisa em fixação biológica de nitrogênio para o desenvolvimento do Brasil. Revista de Econômia Rural, v.18, p.447-460, 1980.

DÖBEREINER, J.; PEDROSA, F.O. Nitrogen-fixing bacteria in non-leguminous crop plants. Madison: Springer Verlag, 1987.

DÖBEREINER, J.; MARRIEL, I.E.; NERY, M. Ecological distribution of Azospirillum lipoferum Beijerinck. Canadian Journal of Microbiology,v.22, p.1464-1473, 1976. 
DÖBEREINER, J.; REIS, V.M.; PAULA, M.A.; OLIVARES, F. Endophytic diazotrophs in sugar cane, cereals and tuber plants. In: PALACIOS R.; MORA, J.; NEWTON, W.E. (Ed.). New Horizons in nitrogen fixation. Dordrecht. 1993. p.671-676.

DOMMERGUES, Y.; BALANDREAU, J.; RINALDO, G.; WEINHARD, P. Nonsymbiotic nitrogen fixation in the tropical rhizosphere of rice, maize and different tropical grasses. Soil Biology and Biochemistry, v.5, p.83-89, 1973.

EARL, C.D.; AUSTUBEL, F.M. The genetic engineering of nitrogen fixation. Nutrition Review, v.41, p.1-6, 1983.

ENGVAll, E., PERLMANN, P. Enzyme-linked immunosorbent assay (ELISA). quantitative assay of immunoglobulin G. Immunochemistry, v.8, p.871-874, 1971.

FALLIK, E.; OKON, Y.; EPSTEIN, E.; GOLDMAN, A.; FISCHER, M. Identification and quantification of IAA and IBA in Azospirillum brasilense inoculated maize roots. Soil Biology Biochemistry, v.21, p.147-153, 1989.

FAO. FERTIILIZERS YEARBOOK - 1992., v.41, p.46, 1992.

FERREIRA, M.C.B.; FERNANDES, M.S.; DÖBEREINER, J. Role of Azospirillum brasilense nitrate reductase in nitrate assimilation by wheat plants. Biology and Fertility of Soils, v.4, p.47-53, 1987. 
FIGUEIREDO, M.B.; ALBA, A.P.C.; OLIVEIRA, A.R. Sorologia aplicada ao estudo dos fungos fitopatológicos. Summa Phytopathologica, v.3, p.233-259, 1977.

FREITAS, J.L.M. de; ROCHA, R.E.M. da; PEREIRA, P.A.A.; DÖBEREINER, J. Matéria orgânica e inoculação com Azospirillum na incorporação de $\mathrm{N}$ pelo milho. Pesquisa Agropecuária Brasileira, v.17, p.1423-1432, 1982.

GABELMAN, W. H.; GERLLOF, G.C. the search for and interpletation of genetic controls that enhance plant growth under deficiency levels of a macrontrient. Plant and Soil, v.72, p.335-350. 1983.

GILLER, K.E.; DAY, J.; DART, P.J.; WANI, S.P. Method for measuring the transfer of fixed nitrogen from free-living bacteria to higher plants using ${ }^{15} \mathrm{~N}_{2}$. Journal Microbiology Methods, v.2, p.307-316, 1984.

GOEBEL, E.M.,; KRIEG, N.R. Frtse catabolism in Azospirillum brasilense and Azospirillum lipoferum. Journal of Bacteriology, v.159, p.86-92. 1984.

HAAHTELA, K.; WARTIOVAARA, T.; SUNDMAN, V.; SKUJINS, J. Rootassociated N2 fixation (acetylene reduction) by Entero-bacteriaceae and Azospirillum strains in cold-climate spodosols. Applied Environment Microbiology, v.41, p.203206, 1981.

HADAS, R.; OKON, Y. Effect of Azospirillum brasilense inoculation on root morphology and respiration and tomato seedlings. Biology Fertilizer Soils, v.5, p.241-247.1987. 
HALK, E.L.; DeBOER, S.H. Monoclonal antibodies in plant-disease research. Annual Review of Phytopathology, v.23, p.321-356,1985.

HARDY, R.W.F.; HOLSTEIN, R.D.; JACKSON, E.K.; BURNS, R.C. The acethylene assay for $\mathrm{N}_{2}$ fixation. Laboratory and field evaluation.. Plant Physiology, v.43, p.1185-1207, 1968.

HARWOOD, R.R. A history of sustainable agriculture. In: EDWARDS, C.A.(Ed.). Sustainable Agricultural systems. Ankeny: Soil and Water Conservation Society of America 1990. p.3-19.

HAWKSWORTH, D.L. The biodiversity of microrganisms and invertbrates: ts role in sustainable agriculture. Melkshan: CAB International, Redwood Press Ltd . 1991. $302 \mathrm{p}$.

HEGAZI, N.A.; MONIB, M.; AMER, H.A.; SHOKR, E.S. Response of maize plants to inoculation with azospirilla and (or) straw amendment in Egypt. Canadian Journal Microbiology, v.29, p.888-889, 1983.

HERRIDGE, D.F.; MARCELLOS, H.; FELTON, W.L.; PEOPLES, M.B. Legume $\mathrm{N}_{2}$ fixation-an efficient source of $\mathrm{N}$ for cereal production. In: Nuclear Related Methods in Soil/Plant Aspects of sustainble Agriculture, FAO/IAEA, Viena. 1994. 
HOBEN, H.J.; SOMASEGARAN, P. Comparison of the pour, spread, and drop plate methods for enumeration of Rhyzobium spp in inoculants made from presterilized peat. Applied and Environmental Microbiology, v.44, n.5, p.1246-1247. 1982.

HOLL, F.B. Plant genetics: manipulation of the host. Canadian Journal of Microbiology, v.29, p.945-953, 1983.

HOREMANS, S.; DE CONINOK, K.; NEVRAY, J.; HERMANS, R.; VLASSAK, K. Production of plant growth substances by Azospirillum sp. and other rhizosphere bacteria. Simbiosis, v.2, p.341-346, 1986.

JORDAN, R.L. Stratagy and techniques for the production of monclonal antibodies; monoclonal antibody application for viruses. In: HAMPTON,R.; BALL, E.; De BOER, S. (Ed.). Serological methods for detection and identification of viral and bacterial plant pathogens. St. Paul: APS Press, 1990 p.55-77.

JORDAN, R.L.; HAMMOND, J. Epitote specificity of strain, virus, subgroupespecific and polyvirus group cross-reactive monoclonal antibodies. Phytopathology, v.78, p. , 1988.

KAPULNIK, Y. Yield response of spring wheat cultivars (Triticum aestivum and $T$. turgidum) to inoculation with Azospirillum brasilense under field conditions. Biology and Fertility of Soils, v.4, p.27-35, 1987. 
KAPULNIK, Y.; SARIG, S.; NUR, I.; OKON, Y.; HENIS, Y. The effect of Azospirillum inoculation on growth and yield of corn. Israel Journal Botany, v.31, p.247-256, 1982.

KAPULNIK, Y.; OKON, Y.;HEIS, Y. Changes in root morphology caused by Azospirillum inoculation. Canadian journal of Microbiology, v.31, p.881-887. 1985.

KENNEDY, A. C. ; SMITH, K.L. Soil microbial diversity and the sustainability of agricultural soils. Plant and Soil, v.170, p.75-86, 1995.

KENNEDY, I.R.; TCHAN, Y.T. Biological nitrogen fixation in non-leguminous field crops, recent advances. Plant and Soil, v.142, n.1/2, p.93-118, 1992.

KHAMMAS, K.M.; AGERON, G.; GRIMONT P.A.; KEISER, P. Azospirillum irakense sp. nov., a nitrogen fiking bacteria associated with rice roots and rhizosphic soil. Research Microbiology, v.140, p.679-693, 1989.

KISHINEVSKY, B.; BAR-JOSEPH, M. Rhizobium strain identification in Arachis hypogaea nodules y enzyme-linked immunosorbet assay ( ELISA). Canadian Journal Microbiology, v.24, p.1537- 1543, 1978.

KISHINEVSKY, B.; GURFEL, D.; LOBEL, R.; NEMAS, C. Use of the enzyme linked immunosorbent assay (ELISA) as a serological screening test in studies of peanut: Rhyzobium strains. Israel Journal of Botany, v.31, p.11 9-130, 1982. 
KLOSSAK, R.M.; BOHLOOL, B.B. Prevalence of Azospirillum spp. in the rhizosphere of tropical grasses. Canadian Journal of Microbiology, v.29, p.649-652, 1983.

KOHLER, G.; MILSTEIN, C. Continuous culture of used cells secreting antobody 6 predefined specificities. Nature, v.256, p.495-497, 1975.

KRIEG, N.R.; DÖBEREINER, J. The genus Azospirillum. In: HOLT, J.G.; KRIEG, N.R. (Eds.). Bergey's manual of systematic bacteriology, 9th edn.. Baltimore: Willians \& Willians, 1986. p.94-104.

LADHA, J.K.; PAREEK, R.P.; BECKER, M. Stem-nodulating legume-Rhizobium symbiosis and its agronomic use in lowland rice. Advanced Soil Science, v.20, p. 147-192, 1982.

LAMM, R.B.; NEYRA, C.A. Characterization and cyst production of Azospirilla isolated from selected grasses growing in New Jersey and New York. Canadian Journal of Microbiology, v.27, p.1320-1325, 1981.

LAZAROVITS, G. The dot immunobinding assay (DIA) - bacteria. In: HAMPTON, R.; BALL, E.; DE BOER, S. (Ed). Serological methods for detection and identification of viral and bacterial plant pathogens. 1990. p.249-263.

LEVANONY, H.; BASHAN, Y. Localization of specific antigens of Azospirillum brasilense $\mathrm{Cd}$ in its exopolysaccharide by immuno-gold staining. Current Microbiology, v.18, p.145-149, 1989. 
LEVANONY, H.; BASHAN, Y.; KAHANA, Z. Enzyme-linked immunosorbent assay for specific identification and enumeration of Azospirillum brasilense $\mathrm{Cd}$ in cereal roots. Applied and Environmental Microbiology, v.53, p.358-64, 1987.

LIMA, E.; BODDEY, R.M.; DÖBEREINER, J. Quantification of biological nitrogen fixation associated with sugar cane using ${ }^{15} \mathrm{~N}$ acid nitrogen balance. Soil Biology and Biochemistry, v.19, p.165-170, 1987.

LIN, W.; OKON, Y.; HARDY, R.W. Enhanced mineral uptake by Zea mays and Sorghum bicolor roots inoculated with Azospirillum brasilense. Applied Environment Microbiology. v.45, p.1775-1779, 1983.

MAGALHÃES, F.M.M.; PATRIQUIN, D.; DÖBEREINER, J. Infection of field grown maize with Azospirillum spp. Revista Brasileira de Biologia, v.39, p.587-596. 1979.

MAGALHÃES, F.M.M.; BALDANI, J.I.; SOUTO, S.M.; KUYKENDALL, J.R.; DÖBEREINER, J. A new acid-tolerant Azospirillum species. Anais da Academia Brasileira de Ciências, v.55, p.417-430, 1983.

MAKAROVA, N.M.; CHUVAEVA, N.A.; KRAVCHENKO, L.V. Serological proprieties of Azospirillum strains. Microbiology, v.60, n.1, p.96-101, 1991

MARRIEL, I.E.; PACHECO, C.A.P.; PURCINO,A.A.C.; MAGALHÃES, J.R. Eficiência no uso de nitrogênio em ppulações de milho cultivadas sob estresse. In: CONGRESSO BRASILEIRO DE FISIOLOGIA VEGETAL. 4., Viçosa. Resumos. Viçosa: SBFV, 1991. P.37. 
MARRIEL, I.E.; SHAFFERT, R.E.; MORO, J.R.; PANTALEĀO, E.; FERRAZ, J.M.G. Aproveitamento de nitrogênio atmosférico em genótipos de milho, sorgo e milheto. In: REUNIÃO BRASILEIRA DE MILHO E SORGO, 12., Goiânia.1978. Anais. Goiânia: SBMS, 1978. p.42.

MARSCHNER, H. Fuctions of mineral nutrition: micronutrients. In: MARSCHNER, H. (Ed.) Mineral nutrition of higher plants. London: Aademic Press, 1986. p.269340 .

MARTENSON, A.M.; GUSTAFSSON, J.G.; LJUNGREN, H.D. A note on a highly sensitive modified enzyme-linked immunosorbent assay (ELISA) for Rhyzobium meliloti strin identification. Journal General Microbiology, v.130, p.103-109, 1984.

MATTHEWS, S.W.; SCHANK, S.C.; ALDRICH, H.C.; SMITH, R.L. Peroxidaseantiperoxidase labeling of Azospirillum brasilense in field-grown pearl millet. Soil Biology Biochemstry. v.6, p.699-703, 1983.

MERNAUG, R.; MERNAUG, G.; KOVACS, G. The immune response: Antigens, antibodies, antigen-antibody interactions. In: HAMPTOM, R. ; BAU, E.; De BOER, S. (Ed).Serological methods for detection and identification of viral and bacterial plant pathogens.St. Paul: APS, 1990. p.3-15.

MICHIELS, K.; VANDERLEYDEN, J.; Von GOOL, A. Azospirillum plant root association: a review. Biology and Fertility Soils, v.8, p.356-368, 1989. 
MURTY, M.G.; LADHA, J.K. Influence of Azospirillum inoculation on the mineral and growth of rice under hydroponic conditions. Plant and soil, v.108, p.81-285. 1988.

NEUMEIER, R. Monoklonale Antikorper in Biologie und Medizin . Biologie in unserer Zeit. v.14, n.4, p.97-102, 1984.

NIELSEN, N.E.; BABER, S.A. Differenes amongs genotypes of corn in the kinetics of P uptake. Agronomy Journal, v.70, p.695-698. 1978.

OKON, Y. Azospirillum as a potential inoculant for agriculture. Trends in Biotechnology, v.3, p.223-228, 1985.

OKON, Y,; ALBRECHT, S.L.; BURRIS, R.H. fFators affecting growth and nitroge fixation of Spirillum lipoferum. Journal of Bacteriology, v.127, p. 1248-1254. 1976.

OKON, Y.; KAPULNIK, Y. Development and function of Azospirillum-inoculated roots. Plant and Soil, v.90, p.3-18, 1986.

OLIVEIRA, O.C. de, URQUIAGA, S.; BODDEY, R.M. Burning cane:the long term effects. Institute of the Sugar Journal, v.96, p.272-275, 1994.

OLSEN, P.E.; RICE, W.A.; STEMKE, G.; PAGE, W.J. Strain -specific serological techniques for the identification of Rhzobium meliloti in commercial alfafa inoculants. Canadian Journal Microbiology, v.29, p.225-230, 1983. 
PAPENDICK, R.I.; PARR, J.F. Soil quality-The key to a sustainable agriculture. American Journal Alternative Agriculture. v.7, p.272-275, 1992.

PATRIQUIN, D.G.; DÖBEREINER, J.; JAIN, D.K. Sites and processes of association between diazotrophs and grasses. Canadian Journal of Microbiology, v.29, p.900-915, 1983.

PEOPLES, M.B.; HERRIDGE, D.F.; LADHA, J.K. Biological nitrogen fixation: An efficient source of nitrogen for sustainable agricultural production? Plant and Soil, v. 174, p.3-28, 1995.

PHAFF, H . Microrganismos industriais. American Scientific, v.245, n.3, p.53-67, 1981.

REINHOLD, B.; HURCK, T.; FENDRIK, I. Strain-specific chemotaxis of Azospirillum spp. Journal of bacteriology, v.162, p.190-195. 1985.

REINHOLD, B.; HURCK, T.; FENDRIK, I.; GILLIS, M.; KERTSERS, K.; THIELEMANS, D.; DE LEY, J. Azospirillum halopraeferans sp. nov. a nitrogen fixing organism associated with roots of kallar grass Leptochloa fusca (L. Kunth). International Journal of Systematics Bacteriology, v.37, p.43-51, 1987.

ROLFE, V.G.; BENDER, G.L. Evolving a Rhizobium for non legume nodulation. In: GRESSHOFF,P.M.; ROTH; L.E.; STACEY G; NEWTON, V.E .Nitrogen fixation: achievements and objectives. New York: Chapman and Hall, 1990. p. 
SARIG, S.; BLUM, A.; OKON, Y. Improvement of the water status and yield of field grown grain sorghum (Sorghum bicolor) by inoculation with Azospirillum brasilense. Journal of Agriculture Science Camb. v.110, p.271-277, 1988.

SCHANK, S.C.; SMITH, R.L.; WEISER G.C.; ZUBERE, D.A.; BOUTON, J.R.; LITTELI, R. Fluorescent antibody technique to identify Azospirillum brasilense associated with roots of grasses. Soil Biology Biochemistry, v.11, p.287-295. 1979.

SCHLOTER, M.; BODE, W.; HARTMANN, A. Characterization of monoclonal antibodies again cell surface structures of Azospirillum brasilense Sp7 using ELISA techniques. Symbiosis, v.13, p.37-45, 1992.

SCHLOTER, M.; BROLINGHAUS, R.; BODE, W.; HARTMANN, A. Diret identification and localization of Azospirillum in the rhizosphere of wheat using fluorescence-labelled monoclonal antibodies and confocal scanning laser microscopy. Journal of Microscopy, v.171, n.2 p.173-177, 1993.

SCHWARZ, K.U. ; GEISLER, G. A rapid screening method to describe genetic variability in root development of cereals. In: McMICHAEL, B. L.; PEARSON, H. (Ed.). Plant roots and their environment. Kiel: Elsevier Science Publishers B.V., 1991. p.632-647.

SELDIN, L.; PENIDO, E.G.C. Identification of Bacillus azotroficans using API tests. Antoinie van Leewenhoek, v.52, p.403-409. 1986. 
SUZUKI, D.T. Inventing the future: reflections on science, techology and nature., St Leonards: Allen and Unwin Pty. 1990. 247p.

TARRAND, J.J.; KRIEG, N.R.; DÖBEREINER, J. A taxonomic study of the Spirillum lipoferum group with description of a new genus, Azospirillum lipoferum gen. nov. and two species: Azospirillum lipoferum sp. Canadian Journal of Microbiology, v.24, p.967-980, 1978.

TANGLEY, L. Crop productivity revisited. BioScience, v.36, p. 142-147, 1986.

TCHAN, Y.T.; ZEMAN, A.M.M.; KENNEDY, I.R. Nitrogen fixation in paranodules of wheat roots by introduced free-living diazotrophs. Plant and Soil, v.137, p.43-47, 1991.

TIEN, T.M.; GASKINS, M.H.; HUBBEL, D.H. Plant growth substances producted by Azospirillum brasilense and their effect on the growth of pearl millet (Panisetum americanum L.). Applied Environmental Microbiology, v.37, p. 1016-1024, 1979.

TSUI, C. The role of zinc in auxin synthess in the tomato plant. Amerivan Journal Botany, v.27, p.939-955. 1948.

VELEZ, D.; MacMILlAN, J.D.; MILLER, L. Production and use of monoclonal antibodies for identification of Bradyrhizobium japonicum strains. Canadian Journal of Microbiology, v.34, p.88-92, 1988. 
VELEZ, D.; REUVENY, S.; MILLER, L.; MacMILLAN, J.D. Kinetics of monoclonal antibody production in low serum growth medium. Journal of Immunology Methods, v.86, p.45-72, 1986.

VIEIRA, R. Aplicação foliar de molibdênio e seu efeito nas atividades de nitrogenase e redutase do nitrato no feijoeiro no campo. Piracicaba, 1994. 188p.(Tese) Doutorado - Escola Superior de Agricultura “Luiz de Queiroz”, Universidade de São Paulo.

VOLLER, A.; BIDWELL, D.E. Enzyme - linked immunosorbens assay (ELISA). In: ROSE,N.; FRIEDMAN, H.; FAHEY, L. (Ed.). Manual of Clinical laboratory immunology. Washington: American society for Microbiology,1986. p.99-109.

WATANABE, I.; YONEYAMA, T.; PADRE, B.; LADHA, J.K. Diference in natural abundance of ${ }^{15} \mathrm{~N}$ in several rice (Oriza sativun, L.) varieties: aplications for evaluating $\mathrm{N}_{2}$ fixation. Soil Science and Plant Nutrition, v.33, p.407-415, 1987.

WRIGHT, S.F.; FOSTER, J.G.; BENNET, O.L. Production and use of monoclonal antibodies for identification of strains of Rhizobium trifolii. Applied and Environmental Microbiology, v.52, p.119-123, 1986.

YOSHIDA, T.; ANCAJAS, R.R. Nitrogen-fixing activity in upland and flooded rice fields. Soil Science Society of American Proceeding,v.37 p.42-46, 1973.

ZUBERER D.A.; ALEXANDER, D.B. Effects of oxigen partial pressure and combined nitrogen on $\mathrm{N}_{2}$ fixation $\left(\mathrm{C}_{2} \mathrm{H}_{2}\right)$ associated with Zea mays and other graminaceous species. Plant and Soil, v.90, p.47-58, 1986. 
APÊNDICE 


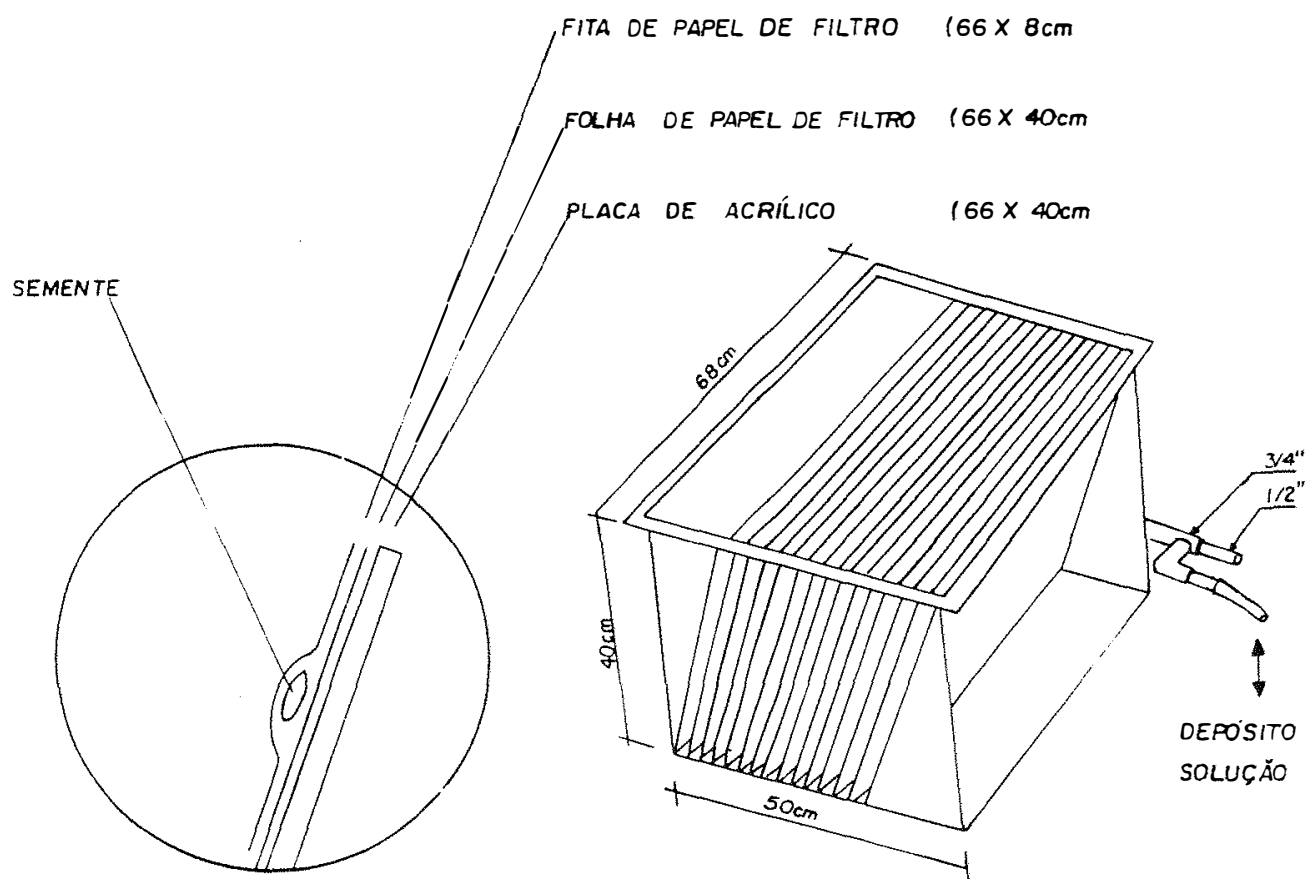

Apêndice 1 - Esquema ilustrativo do sistema usado para avaliação da morfologia do sistema radicular das plantas. 
Apêndice 2 - Lista de alguns isolados de diazotróficos obtidos de origens diversas e identificados ${ }^{1}$ utilizando-se parâmetros morfológicos e fisiológicos.

\begin{tabular}{|c|c|c|}
\hline Isolado & Origem & Identificação \\
\hline 2 & Raiz lavada de sorgo. Sete Lagoas, MG & $\mathrm{ND}^{2}$ \\
\hline 12 & Raiz lavada de sorgo. Sete Lagoas, MG & ND \\
\hline 13 & Raiz lavada de sorgo. Sete Lagoas, MG & ND \\
\hline 13.1 & Raiz lavada de sorgo. Sete Lagoas, MG & ND \\
\hline 13.2 & Raiz lavada de sorgo. Sete Lagoas, MG & ND \\
\hline 14 & Raiz lavada de sorgo. Sete Lagoas, MG & ND \\
\hline 15 & Raiz lavada de sorgo. Sete Lagoas, MG & ND \\
\hline 15.1 & Raiz lavada de sorgo. Sete Lagoas, MG & ND \\
\hline 18 & Raiz lavada de sorgo. Sete Lagoas, MG & ND \\
\hline 20 & Raiz lavada de sorgo. Sete Lagoas, MG & ND \\
\hline 20.1 & Raiz lavada de sorgo. Sete Lagoas, MG & ND \\
\hline 22 & Raiz lavada de sorgo. Sete Lagoas, MG & ND \\
\hline 22.1 & Raiz lavada de sorgo. Sete Lagoas, MG & ND \\
\hline 22.2 & Raiz lavada de sorgo. Sete Lagoas, MG & ND \\
\hline 23 & Raiz lavada de sorgo. Sete Lagoas, MG & ND \\
\hline 28 & Raiz lavada de sorgo. Sete Lagoas, MG & ND \\
\hline 28.1 & Raiz lavada de sorgo. Sete Lagoas, MG & ND \\
\hline 29 & Raiz lavada de sorgo. Sete Lagoas, MG & ND \\
\hline 29.1 & Raiz lavada de sorgo. Sete Lagoas, MG & ND \\
\hline 30 & Raiz lavada de milho. Sete Lagoas, MG & ND \\
\hline 30.1 & Raiz lavada de milho. Sete Lagoas, MG & ND \\
\hline 31 & Seiva de sorgo. Sete Lagoas, MG & ND \\
\hline 31.1 & Seiva de sorgo. Sete Lagoas, MG & ND \\
\hline 33 & Raiz lavada de sorgo. Sete Lagoas, MG & ND \\
\hline 33.1 & Raiz lavada de sorgo. Sete Lagoas, MG & ND \\
\hline 34 & Raiz lavada de sorgo. Sete Lagoas, MG & ND \\
\hline 36 & Raiz lavada de sorgo. Sete Lagoas, MG & ND \\
\hline 37 & Raiz lavada de sorgo. Sete Lagoas, MG & ND \\
\hline 38 & Raiz lavada de sorgo. Sete Lagoas, MG & ND \\
\hline 38.1 & Raiz lavada de sorgo. Sete Lagoas, MG & ND \\
\hline 42 & Raiz lavada de sorgo. Sete Lagoas, MG & A. brasilense \\
\hline 42.1 & Raiz lavada de sorgo. Sete Lagoas, MG & A. brasilense \\
\hline 43 & Raiz lavada de sorgo. Sete Lagoas, MG & A. lipoferum \\
\hline 43.1 & Raiz lavada de sorgo. Sete Lagoas, MG & A. lipoferum \\
\hline
\end{tabular}


43.2

44

45

45.1

46

53

54

71

73

79

95

95.1

97

98

99

101

101.1

103

119

125

125.1

132

132.1

157

157.1

158

158.1

159

159.1

160

161

161.1

162.1

163.1

164

164.1

165

166
Raiz lavada de sorgo. Sete Lagoas, MG

Raiz lavada de sorgo. Sete Lagoas, MG

Raiz lavada de sorgo. Sete Lagoas, MG

Raiz lavada de sorgo. Sete Lagoas, MG

Seiva de sorgo. Sete Lagoas, MG

Seiva de sorgo. Sete Lagoas, MG

Raiz lavada de milho. Sete Lagoas, MG

Seiva de milho. Sete Lagoas, MG

Seiva de sorgo. Sete Lagoas, MG

Seiva de sorgo. Sete Lagoas, MG

Seiva de sorgo. Sete Lagoas, MG

Seiva de sorgo. Sete Lagoas, MG

Seiva de milho. Sete Lagoas, MG

Seiva de milho. Sete Lagoas, MG

Seiva de sorgo. Sete Lagoas, MG

Seiva de milho. Sete Lagoas, MG

Seiva de milho. Sete Lagoas, MG

Seiva de sorgo. Sete Lagoas, MG

Seiva de sorgo. Sete Lagoas, MG

Seiva de milho. Sete Lagoas, MG

Seiva de milho. Sete Lagoas, MG

Seiva de milho. Sete Lagoas, MG

Seiva de milho. Sete Lagoas, MG

Grãos de milho, Piracicaba, SP

Grãos de milho, Piracicaba, SP

Raiz lavada de milho. Piracicaba, SP

Raiz lavada de milho. Piracicaba, SP

Raiz lavada de milho. Piracicaba, SP

Raiz lavada de milho. Piracicaba, SP

Estígma de milho. Piracicaba, SP

Grãos de milho. Piracicaba, SP

Grãos de milho. Piracicaba, SP

Efluente de microdestilaria. Piracicaba, SP

Efluente de microdestilaria. Piracicaba, SP

Grãos de milho. Piracicaba, SP

Grãos de milho. Piracicaba, SP

Raiz lavada de milho. Piracicaba, SP

Raiz lavada de milho. Piracicaba, SP
A. lipoferum

A. lipoferum

A. brasilense

A. brasilense

A. lipoferum

A. lipoferum

A. lipoferum

A. brasilense

A. lipoferum

A. lipoferum

A. brasilense

A. lipoferum

A. lipoferum

A. brasilense

A. brasilense

A. brasilense

A. brasilense

A. brasilense

A. brasilense

A. lipoferum

A. brasilense

A. brasilense

A. brasilense

A. lipoferum

A. lipoferum

A. lipoferum

A. lipoferum

A. lipoferum

A. lipoferum

A. lipoferum

A. lipoferum

A. lipoferum

A. lipoferum

A. lipoferum

A. brasilense

A. lipoferum

A. lipoferum

A. lipoferum 
167

168

168.1

170

171

172

173

174

175

175.1

176

182

186

187

192

194

195

196

200

213

215

215.1

216

217

218

219

220

221

222

222.1

223

224

224.1

226

227

228

229
Estigma de milho. Piracicaba, SP

Estigma de milho. Piracicaba, SP

Estigma de milho. Piracicaba, SP

Estigma de milho. Piracicaba, SP

Seiva de milho. Piracicaba, SP

Raiz lavada de milho. Piracicaba, SP

Grãos de milho. São Carlos, SP

Seiva de milho. Piracicaba, SP

Raiz lavada de milho. Piracicaba, SP

Raiz lavada de milho. Piracicaba, SP

Grãos de milho. Piracicaba, SP

Seiva de milho. Piracicaba, SP

Lesões de semente de feijão. Sete Lagoas, MG

Raiz esterilizada de milho. Sete Lagoas, MG

Raiz esterilizada de milho. Sete Lagoas, MG

Lesões de semente de feijão. Sete Lagoas, MG

Lesões de semente de feijão. Sete Lagoas, MG

Lesões de semente de feijão. Sete Lagoas, MG

SP7

Lesões de semente de feijão. Sete Lagoas, MG

Capim. Piracicaba, SP

Capim. Piracicaba, SP

Raiz de centeio. Sete Lagoas, MG

Seiva de milho. Piracicaba, SP

Capim colonião. Sete Lagoas, MG

Raiz de sorgo. Piracicaba, SP

Lesões de semente de feijão. Sete Lagoas, MG

Seiva de milho. Sete Lagoas, MG

Capim colonião. Sete Lagoas, MG

Capim colonião. Sete Lagoas, MG

Lesões de semente de feijão. Sete Lagoas, MG

Solo da rizosfera de milho, Sete Lagoas, MG

Solo da rizosfera de milho, Sete Lagoas, MG

Lesões de semente de feijão. Sete Lagoas, MG

Raiz de sorgo. Espirito Santo, ES

Seiva de milho. Sete Lagoas, MG

Seiva de milho. Sete Lagoas, MG
A. lipoferum

A. lipoferum

A. lipoferum

A. lipoferum

A. lipoferum

A. lipoferum

A. lipoferum

A. brasilense

A. lipoferum

A. lipoferum

A. brasilense

A. lipoferum

A. lipoferum

A. lipoferum

A. lipoferum

A. brasilense

A. lipoferum

A. brasilense

A. lipoferum

A. lipoferum

A. lipoferum

A. lipoferum

A. lipoferum

A. lipoferum

A. brasilense

A. lipoferum

A. lipoferum

A. lipoferum

A. lipoferum

A. lipoferum

A. brasilense

A. lipoferum

A. lipoferum

A. brasilense

A. lipoferum

ND

ND 
Seiva de milho. Sete Lagoas, MG

Seiva de milho. Sete Lagoas, MG

Raiz de milho. Sete Lagoas, MG

Raiz de centeio. Sete Lagoas, MG

Seiva de sorgo. Sete Lagoas, MG

Lesões de semente de feijão. Sete Lagoas, MG

Raiz de milho. Piracicaba, SP

Solo da rizosfera de milho, Sete Lagoas, MG

${ }^{1}$ Identificação foi efetuada de acordo com os critérios recomendados por Döbereiner et al. (1995).

${ }^{2} \mathrm{ND}$ - isolado não identificado. 